\title{
Hydrochemical characterization of shallow and deep groundwater in Basement Complex areas of southern Kebbi State, Sokoto Basin, Nigeria
}

\author{
Saadu Umar Wali ${ }^{1}$ - Kabiru Jega Umar ${ }^{2}$. Sheikh Danjuma Abubakar ${ }^{3}$. Ifatokun Paul Ifabiyi ${ }^{4}$. \\ Ibrahim Mustapha Dankani ${ }^{3}$. Ibrahim Muhammad Shera ${ }^{1}$ · Safiyanu Garba Yauri ${ }^{1}$
}

Received: 25 April 2018 / Accepted: 23 September 2019 / Published online: 4 October 2019

(c) The Author(s) 2019

\begin{abstract}
Groundwater under Basement Complex areas of southern Kebbi has been characterized in order to determine its suitability for drinking and irrigation use. Water samples were drawn from shallow groundwater (hand-dug shallow wells $<5 \mathrm{~m}$ ) and deep groundwater (boreholes $>40 \mathrm{~m}$ ). Physical parameters (i.e., temperature, TDS, $\mathrm{pH}$, and EC), were determined in situ, using handheld meters. Discrete water samples were obtained for determination of chemical parameters. Results from severalsample ANOVA (Kruskal-Wallis test) suggested that heterogeneity in water table appeared to exert significant influence on groundwater chemistry which is characterized by a significant difference in $\mathrm{pH}, \mathrm{EC} \mathrm{TH}, \mathrm{Na}^{+}, \mathrm{Zn}^{2+}, \mathrm{Mg}^{2+}, \mathrm{PO}_{4}{ }^{3-}, \mathrm{Cl}^{-}$, $\mathrm{HCO}_{3}{ }^{-}, \mathrm{SO}_{4}{ }^{2-}$, and $\mathrm{NO}_{3}{ }^{-}$concentrations. Also, ions including $\mathrm{Fe}^{3+}, \mathrm{Zn}^{2+}, \mathrm{Mg}^{2+}, \mathrm{Na}^{+}, \mathrm{PO}_{4}{ }^{3-}$, and $\mathrm{SO}_{4}{ }^{2-}$ are above World Health Organization (2011) and National Standard for Drinking Water Quality (2007) reference guidelines. Most of the groundwater sources are moderately hard. Groundwater classification based on chloride, EC, and TDS revealed water of excellent quality for all types of uses. However, groundwater classification based on nitrate pollution revealed water of poor quality. Rock mineral is the major mechanism controlling water chemistry, as revealed by the Gibbs model. Most of the water sources have positive Scholler index, indicative of overall base exchange reactions in the underlying aquifers. Such condition was well explained by Piper trilinear diagram, which revealed two types of faces: $\mathrm{Ca}-\mathrm{Mg}-\mathrm{HCO}_{3}$ and $\mathrm{Ca}-\mathrm{Mg}-\mathrm{SO}_{4}-\mathrm{Cl}$. The HCA categorized wells into three groups according to their hydrogeochemical physiognomies. Despite the significant difference in ions concentration and chemical indices, groundwater composition is more influenced by rock weathering than anthropogenic inputs. Groundwater evaluation for irrigation use indicates a significant difference in SAR level which is related to poor permeability index in shallow groundwater. Higher values of Kelly's index and magnesium adsorption ratio threatened groundwater suitability for irrigation use in the study area.
\end{abstract}

Keywords Sodium adsorption ratio $\cdot$ Sodium hazard $\cdot$ Magnesium hazard $\cdot$ Scholler index $\cdot$ Kelly's index $\cdot$ Molar ratio

Saadu Umar Wali

saadu.wali@fubk.edu.ng

Kabiru Jega Umar

kabiru.umar@fubk.edu.ng

Sheikh Danjuma Abubakar elsheikh1968@gmail.com

Ifatokun Paul Ifabiyi

tokunifabiyi@unilorin.edu.ng

Ibrahim Mustapha Dankani imdankani@gmail.com

Ibrahim Muhammad Shera imshera80@gmail.com
Safiyanu Garba Yauri suffee2@gmail.com

1 Department of Geography, Federal University Birninkebbi, Kebbi State, Nigeria

2 Department Pure and Applied Chemistry, Federal University Birninkebbi, Kebbi State, Nigeria

3 Department of Geography, Usmanu Danfodiyo University Sokoto, Sokoto State, Nigeria

4 Department of Geography, University of Ilorin, Kwara State, Nigeria 


\section{Introduction}

Groundwater is one of the most important environmental reserves exploited for industrial, agricultural, and domestic uses (Wagh et al. 2016). The composition of groundwater tends to be good in most natural aquifers, and as a result, groundwater is increasingly been exploited as it meets the basic requirements for most uses. Groundwater quality is primarily influenced by the aquifer rock mineral and recharge pathways (Kohlhepp et al. 2017; Liu et al. 2017; Gu et al. 2017; Kumar et al. 2019). As water passes through its recharge pathways from recharge to discharge points, several other types of hydrogeochemical processes alter its physical and chemical properties and in some aquifers, water may be unsuitable for drinking and agriculture (Abd El-Aziz 2017; Dehnavi et al. 2011; Farid et al. 2017). At least, one-third of the global population rely on groundwater for drinking (Panaskar et al. 2016). While groundwater is increasingly exploited in response to population pressure (Bertrand et al. 2016; Shang et al. 2016; Parisi et al. 2018; Cavalcante Júnior et al. 2019), increased urbanization (Minnig et al. 2018; Tam and Nga 2018; Hughes 2019), industrialization (Zheng et al. 2019) and irrigation farming (Panaskar et al. 2016; Fabbri et al. 2016; Pulido-Bosch et al. 2018), only about $22 \%$ of the Earth's $37 \mathrm{~km}^{3}$ (freshwater) is found in aquifers as groundwater (Panaskar et al. 2016). Remarkably, about 97\% of this quantity is accessible for human use (Panaskar et al. 2016). Overexploitation of groundwater in key sedimentary aquifers is a global phenomenon (Joshi et al. 2018). The rate of annual global groundwater withdrawal, even though may vary with climate and geography, is about $1500 \mathrm{~km}^{3}$, which is above the normal rates of annual global groundwater recharge or replenishment (Joshi et al. 2018).

Growing demand for water driven by economic growth (Hertel and Liu 2016; Kummu et al. 2016; Shahzad et al. 2017; Flörke et al. 2018), urbanization (Kulabako et al. 2007; Sperling and Sarni 2019), generation of electricity (Powell et al. 2019), irrigation (Erban and Gorelick 2016; Wu et al. 2016), and domestic uses has inflamed global groundwater withdrawal (Shahid et al. 2015; Wada et al. 2016; Veldkamp et al. 2017; Agarwal and Garg 2015; Thomas et al. 2019), causing water table declines in aquifers (Joshi et al. 2018). Shallow groundwater is often the most affected by small-scale irrigation farming ( $\mathrm{Li}$ et al. 2018), particularly in developing countries. In alluvial basins (e.g., Sokoto Basin), groundwater pollution is primarily derived from reinfiltering groundwater from irrigation fields (Selck et al. 2018) and municipal and industrial sewage (Wali et al. 2018a, b). Geophysical investigations showed alluvial aquifers (e.g., Sokoto Basin) are often in hydraulic conductivity with surface water (Emujakporue et al. 2018; Kudamnya and Andongma 2017; Nwankwo 2015; Nwankwo and Shehu 2015; Onuigbo et al. 2017), with shallow aquifers serving as conduits through which pollutants from surface water are transported to deep groundwater reservoirs.

There are immeasurable number of studies comparing groundwater quality between shallow and deep aquifers around the world: Basharat (2012), assessed the groundwater quality by demarcating the zones where brackish water exists in the form of depths and zones; Brancelj et al. (2016), showed variations in physical and chemical composition between shallow boreholes in distinct aquifers situated a few kilometers away from each other; Das and Mukherjee's (2019), depth-dependent groundwater response to coastal hydrodynamics, showed variability in salinity between 1 and 4 ppt at $>100 \mathrm{mbgl}$ depths, indicating a mixing between chemically discrete groundwater aquifers; Hubalek et al. (2016) showed that deepest aquifers had the least taxon richness and unexpectedly held Cyanobacteria; Pandith et al. (2017) revealed differences in fluoride absorption in shallow (basalt -10 to $167 \mathrm{~m}$ ) and deeper (granite less than $167 \mathrm{~m}$ ) aquifers; Rajmohan et al. (2017) also discovered variability of water quality of deep and shallow wells; Holbrook et al.'s (2019) analysis of the relationship between physical and chemical showed that weathering occurs from a 65 -m-deep well over earth's critical zone; and Long et al. (2019) outlined a cavernous rotation and regularity of groundwater movement between aquifers. Evaluations of this kind are imperative since they help to describe the connections between groundwater tables, and this affects both the quality of shallow and groundwater aquifers (Hubalek et al. 2016; Park et al. 2018; Holbrook et al. 2019).

However, groundwater has been studied using different techniques: geothermal techniques (Nwankwo 2015; Nwankwo and Shehu 2015; Olatunji and Musa 2013; Toyin et al. 2016), isotope techniques (Adelana et al. 2003; Geyh and Wirth 1980; Fillion et al. 2014, 2018; Selck et al. 2018; Kattan 2018; Alemayehu et al. 2019; Besser et al. 2019), multivariate statistics (Mondal et al. 2010; Azhar et al. 2015; Yidana et al. 2018), univariate statistics (Marghade et al. 2010; Selvakumar et al. 2017; Wali et al. 2018a, b), modeling (Ebrahim et al. 2019; Locatelli et al. 2019), and chemical indices (Marghade et al. 2010; Panaskar et al. 2016; Wagh et al. 2016). Results obtained from these studies showed groundwater quality is influenced by both the natural geogenic processes and anthropogenic activities. In some environments, the groundwater quality is largely dependent on the water table depths (Dhar et al. 2008; Han et al. 2013; Deng et al. 2014).

Nigeria is the fastest growing country in sub-Saharan Africa (SSA) in terms of the human population (Akombi et al. 2019; Young 2019). Improved water supply which is 


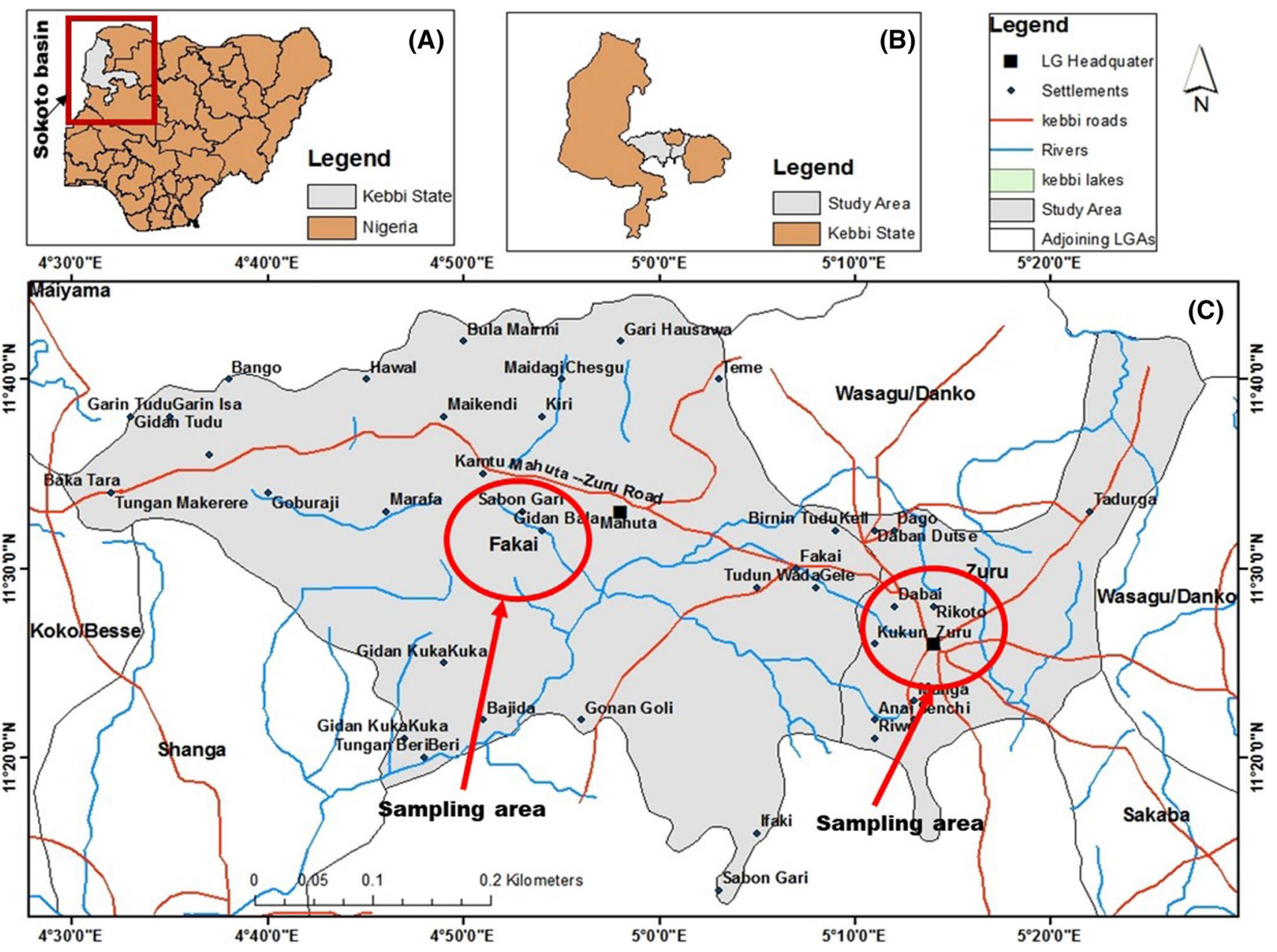

Fig. 1 Map of the study area a Sokoto Basin; b Kebbi State; and c Study area

one of the essentials for a healthy living has been constrained by uncontrolled anthropogenic activities (Vijay et al. 2011; Qin et al. 2013; Chen et al. 2016; Chitsazan et al. 2019) and by lesser extent natural conditions (Izah et al. 2016; Makinde et al. 2017; Zadawa and Omran 2018). Characterization of groundwater in Nigeria, is further constrained by lack of data, especially from Basement Complex areas of northern Nigeria (Akinluyi et al. 2018; Olubusola et al. 2018; Oyedele and Olayinka 2019; Tajudeen et al. 2019), owing to difficulties associated with groundwater exploration and accessibility (Betzler et al. 2017; Muhammad and Saad 2018; Oyeyemi and Aizebeokhai 2018; Ahmed and Mansor 2018).

The Basement Complex areas of southeastern Sokoto Basin are in southern Kebbi State (Fig. 1) and are underlain by Pre-Cambrian Basement Formation (Akujieze et al. 2002; Joseph and Bamidele 2018; Oseji and Egbai 2019). Groundwater in the study area is generally available in small quantity derived from fractures and tabular partings and from the regolith, just below the earth surface (Anderson and Ogilbee 1973; Edet 1990; Paul and Bayode 2012; Odukoya 2015). The fissures are usually most open above a depth of $91 \mathrm{~m}$ but even so, yields to boreholes are relatively low and cause high drawdown (Anderson and Ogilbee 1973; Offodile 2002). While boreholes are widely used in the study area as sources for improved water supply, shallow groundwater remained the most reliable source of drinking water especially in rural areas (Mohammed et al. 2007; Adelana et al. 2003; Aleke and Nwachukwu 2018; Olorunfemi and Oni 2019). However, the geological settings in addition to changes in land use combined with rock mineral influence groundwater composition (Dehnavi et al. 2011; Khatri and Tyagi 2014; Redwan and Abdel Moneim 2016; Venkatramanan et al. 2017; Jebreen et al. 2018; Mukate et al. 2019). Effluents from municipal, industrial, and crop fields are transported to groundwater by surface flows via infiltration (recharge) zones. These impurities are first collected 
into shallow aquifers (Kong et al. 2018; Narr et al. 2019), before their eventual downward movement to deep groundwater reservoirs, where they may stay for decades or even centuries.

To highlight this problem, we look at the Basement Complex areas of southeastern Sokoto Basin. The study area is underlain by intrusive granite of igneous origin and deformed metamorphic rocks, chiefly gneiss, schist, hyalite, and quartzite (Toyin et al. 2016; Toyin and Adekeye 2019; Omolabi and Fagbohun 2019). Groundwater in this type of aquifer (often one-aquifer system), tend to be highly mineralized. Further, the topography of the study area presents another obstacle to groundwater development (Kogbe 1986). Therefore, groundwater is cheaply found along with low-lying areas and is largely hauled out using handlines from shallow wells particularly in rural areas (Anderson and Ogilbee 1973; Offodile 2002). Groundwater quality studies in Sokoto Basin (du Preez and Berber 1965; Anderson and Ogilbee 1973; Adelana et al. 2003; Amadi et al. 2015; Ekpoh and Ekpenyong 2011; Ette et al. 2017; Toyin et al. 2016; Wali et al. 2016, Wali et al. 2018a, b) revealed water of excellent quality and of Holocene age (100-10,000 years BP). These studies were carried out in Cretaceous and Cenozoic Sediment sections of north-western and central Sokoto Basin. Groundwater quality in the Basement Complex section of southeastern Sokoto Basin remained poorly reported in the literature (Anderson and Ogilbee 1973; Offodile 2002; Nwankwoala 2015), even though hydrochemical evaluation of groundwater over space and time proved to be an important technique for solving different hydrogeochemical problems (Edmunds 2009; Li et al. 2018; Yin et al. 2019). Understanding the aquifer hydrochemistry is important for effective utilization of, and development of this finite resource (Kashiwagi et al. 2006). Thus, the objective of this study is to assess the variability of groundwater quality between shallow and deep aquifers and evaluate its suitability for drinking and irrigation uses.

\section{The study area}

\section{Location and climate}

The Basement Complex areas of southeastern Sokoto Basin are in southern Kebbi State. The study area is situated between Latitudes $11^{\circ} 20^{\prime \prime}$ and $11^{\circ} 40^{\prime \prime} \mathrm{N}$ and Longitudes $4^{\circ} 30^{\prime \prime} \mathrm{E}$ and $5^{\circ} 30^{\prime \prime} \mathrm{E}$ (Fig. 1) and covers about $2411.69 \mathrm{~km}^{2}$. This area overlays Fakai and Zuru local government areas (LGAs). From the conglomeration point along Koko-Mahuta road, just about $40 \mathrm{~km}$ before Mahuta, surface elevation increases steadily passing through Fakai and reaching over $400 \mathrm{~m}$ above sea level in Dabai. The rock outcrops formed a triangle of basement rock outcrop, which extends from Fakai to Zuru and Yauri.

The climate of the study area is hot, semiarid tropical (AW) in Koppen's classification. It is dominated by two opposing wind systems: Tropical Maritime and Tropical Continental air masses (Gada 2014). These give the study area two contrasting seasons-wet and dry. The dry season results from continental air mass blowing from the Sahara Desert. The dry season lasts from October to April, whereas wet season lasts from May to October. From March onward, the temperature rises to over $35^{\circ} \mathrm{C}$ (Fig. 2a). Temperature is generally high and showed marked seasonal variation. Mean maximum temperature is highest in April. Mean minimum temperature is the lowest in December $<20{ }^{\circ} \mathrm{C}$. Monthly rainfall ranges from $<50 \mathrm{~mm}$ to over $250 \mathrm{~mm}$. Most of the precipitation falls in July, August, and September (Fig. 2b).
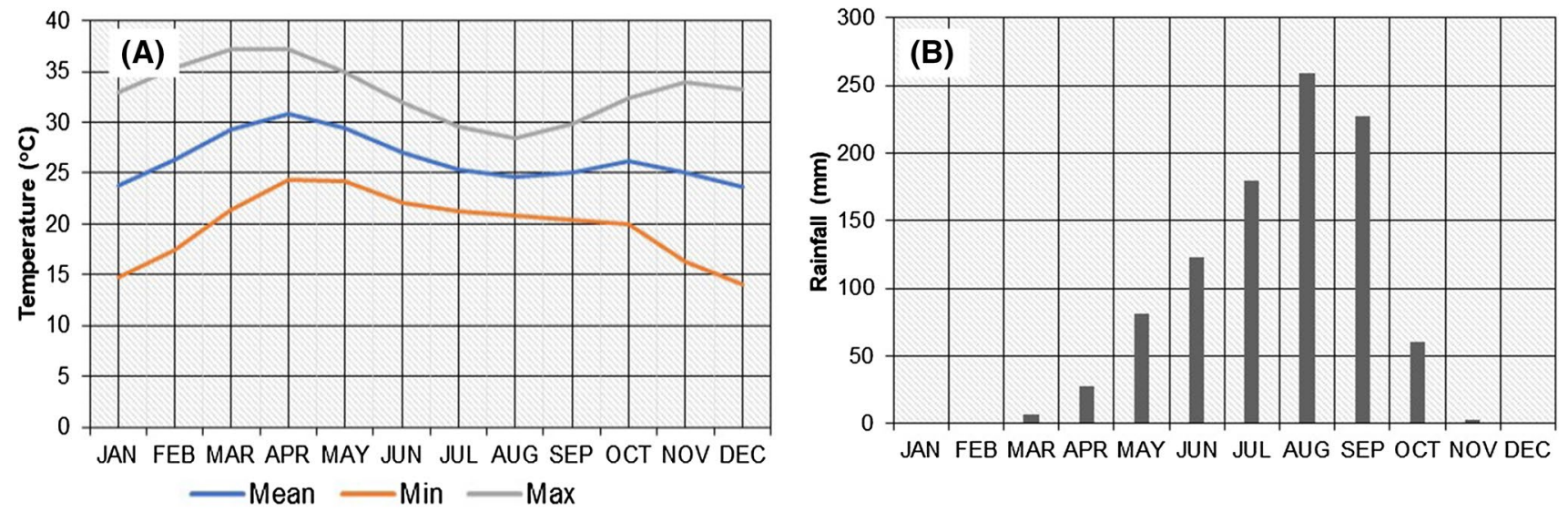

Fig. 2 A chart showing the variability of a temperature; and $\mathbf{b}$ rainfall in the study area. Source of Data: Climate-Data Org. Retrieved from https ://en.climate-data.org/africa/nigeria/kebbi/zuru-380580/on 10/06/2019 


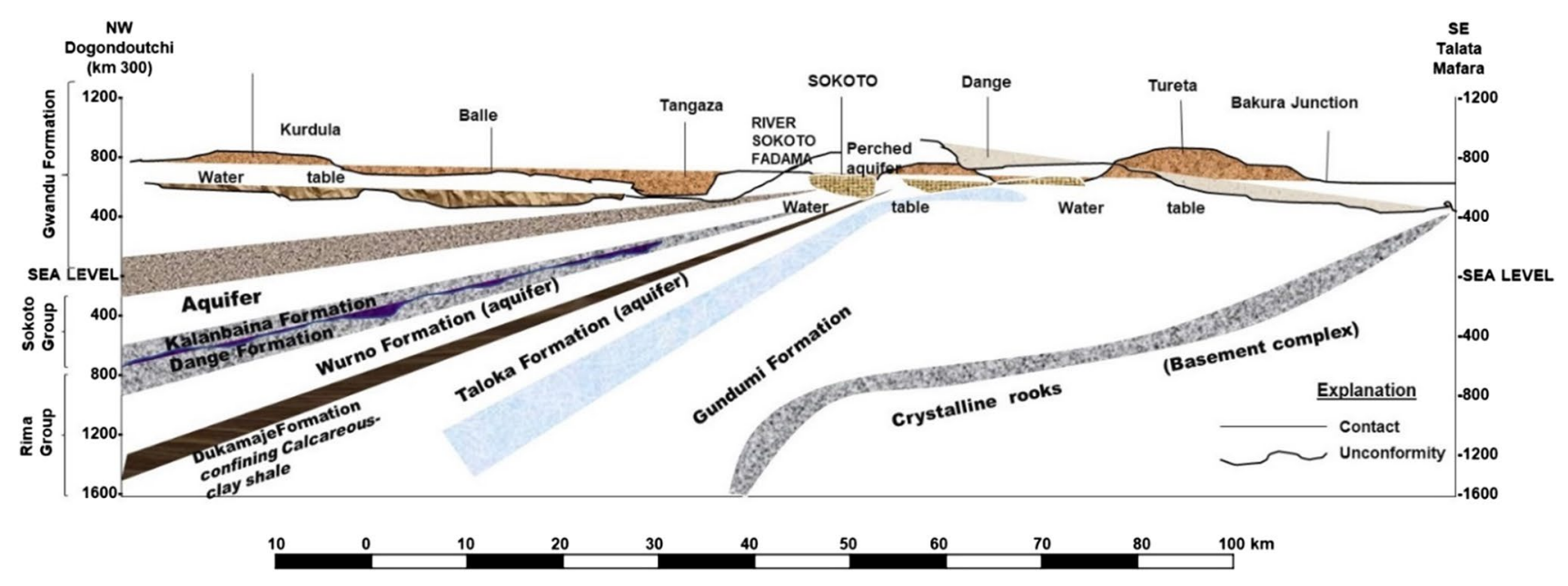

Fig. 3 The geological cross section of Sokoto Basin

\section{Geological setting}

Figure 3 shows the geological cross section of Sokoto Basin. In terms of geology, the Sokoto Basin is extensively studied (Emujakporue et al. 2018; Ette et al. 2017; Kogbe 1981; Moody and Sutcliffe 1991; Nwankwo 2015; Nwankwo and Shehu 2015; Onuigbo et al. 2017). The sediments of Sokoto Basin were accrued during three main stages of deposition, i.e., the first and last phases were the continental Mesozoic and Tertiary, with a second phase which is the marine Maastrichtian to Paleocene. Superimposing the Pre-Cambrian Basement unconformably are the grits and clays of the Illo and Gundumi Formations, forming part of the "Continental Intercalaire" of West Africa (Emujakporue et al. 2018; Kamba et al. 2018; Kogbe 1981; Moody and Sutcliffe 1991). These formations are superimposed unconformably by the Rima Group (Maastrichtian), consisting of mudstones and friable sandstones (Taloka and Wurno Formations), separated by the fossiliferous, shelly Dukamaje Formation (Emujakporue et al. 2018; Kamba et al. 2018; Kogbe 1981; Moody and Sutcliffe 1991). The Dange and Gamba Formations (mainly shales) of Paleocene are separated by the Kalambaina Formation (Calcareous). The Gwandu Formation (Continental Terminal) which covers these formations is of Tertiary age. These sediments dip gently and thicken gradually toward the northwest, with a maximum thickness of over $1200 \mathrm{~m}$ near the border with the Niger Republic (Emujakporue et al. 2018; Kamba et al. 2018; Kogbe 1981; Moody and Sutcliffe 1991).

\section{Hydrogeological setting}

Lying below the sedimentary rocks of the Sokoto Basin and rising to the land surface in the highlands to the south and east of the basin are crystalline rocks of pre-Cretaceous age. These comprise of plutonic granite of igneous derivation and warped metamorphic rocks, mainly gneiss, schist, phyllite, and quartzite (Kogbe 1986). Groundwater in the high ground zones of crystalline rocks is usually obtainable in small amounts from fissures or other flat separations and from the regolith (worn rock) just underneath the ground surface (Anderson and Ogilbee 1973). The fissures are typically found above a depth of $91.44 \mathrm{~m}$ but, even so, yields to boreholes are rather low and cause high drawdowns (Anderson and Ogilbee 1973). The formation is Pre-Cambrian in age and is made up of schists, granite gneisses, phyllites, and quartzite. Of hydrogeological importance is the slight, north-south elongate belt of metasediments intersecting the basement rocks. The formation is splintered in places and occasionally deeply battered below ground surface. Likewise, the western peripheries of the basement rocks are marked by penetrating fracture systems (Anderson and Ogilbee 1973).

Hydrogeological studies of the pre-Cretaceous Basement Complex Formations of Nigeria (Akinluyi et al. 2018; Anderson and Ogilbee 1973; Olorunfemi and Oni 2019), revealed an average borehole yield of 14.67 gallons per sec (gps) from a mean depths of $37.49 \mathrm{~m}$. Though, few boreholes in the unweathered rock, typically granite or gneiss produced more than a meager amount of water; in many wells, no water was found (Anderson and Ogilbee 1973). In contrast, wells tapping weathered granite and gneiss, where fully saturated, are found to yield the highest quantity of water (51.67 gps); the average yield for boreholes tapping battered rock was estimated to be around 23.33 gps per borehole (Anderson and Ogilbee 1973). Also, drawdowns during pumping were very high $(62.48 \mathrm{~m})$ from some wells. The normal depth of wells tapping the weathered materials is estimated to be $38 \mathrm{~m}$

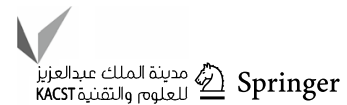


Fig. 4 Lithologic section of boreholes in the study area Zuru and b Fakai

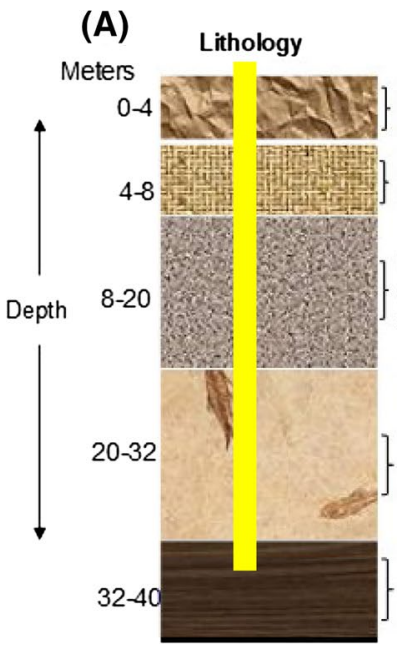

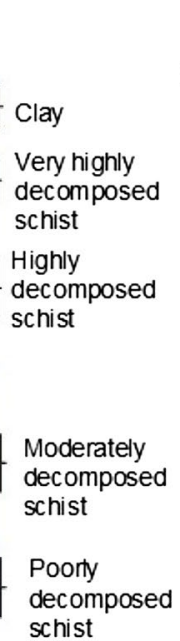

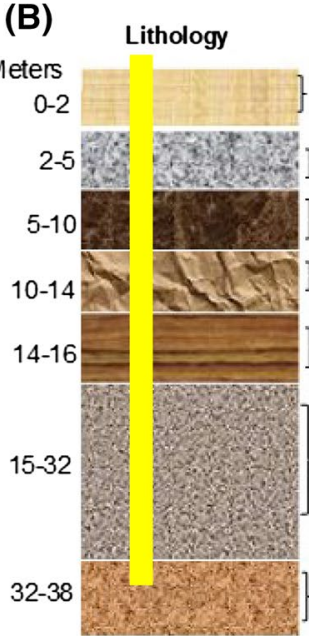

Topsoil

\section{Iron stone}

Lateritic sand

Lateritic clay and schist fragments

Fine grain sand

Highly decomposed biotite schist

Moderately decomposed biotite schist with sand and the normal depth to water stand at about $6 \mathrm{~m}$ (Anderson and Ogilbee 1973). Generally, groundwater condition in the basement section of Sokoto Basin is typical of the Nigerian Basement Complex described by (Akinluyi et al. 2018; Olorunfemi and Oni 2019).

Many wells were developed in the crystalline rocks particularly in the eastern parts of the basin (Gusau-Mafara axis). The borehole yield was found to be higher in the metasediments with splintered quartzites (Anderson and Ogilbee 1973). Yet borehole in most parts of the Basement Complex section of the basin is low. This kind of poor yields is also characteristic of Basement Complex Formation of Nigeria. Such low yield zone results from aquifers of weathered or fractured materials, with limited areal scope, such that during pumping or well development the spreading cone of depression hits the highly indurated frontier rocks in a short time (Akinluyi et al. 2018; Anderson and Ogilbee 1973; Olorunfemi and Oni 2019). The water level, or the drawdown, drops sharply and steadily decrease the yield per individual boreholes. Numerous boreholes and hand-dug wells have been drilled in the area and are still been drilled or dug in the Basement Complex zones of the basin for both the rural and urban water supply. High yields can be attained in some areas in the Basement Complex, contingent on the tectonics in those areas. Despite the poor yields, boreholes and hand-dug wells in Basement Complex zones are sufficient to sustain hand pumps, in rural water supply programs (Akinluyi et al. 2018; Anderson and Ogilbee 1973; Olorunfemi and Oni 2019). Figure 4 illustrates a typical lithologic section of the study area.

\section{Groundwater quality}

Geological work in Sokoto Basin dates to 1800 s. Reporting of fossil fuel localities was the main objective. A
Comprehensive study of groundwater was carried out by du Preez and Berber (1965). Groundwater recharge (Adelana et al. 2002) is highly variable across the basin. Groundwater quality (Anderson and Ogilbee 1979; Uma 1993; Alagbe 2006; Graham et al. 2006; Wali et al. 2016; Wali and Bakari 2016; Wali et al. 2018a, b) is highly variable with TDS concentration ranging from 130 to $2340 \mathrm{mg} / \mathrm{l}$. Sodium and nitrate concentrations exceed WHO reference guidelines in some locations. The hydrogeochemical faces (Alagbe 2006; Wali et al. 2018a, b) are predominantly of two types: calcium-magnesium-bicarbonate and calcium-magnesium-sulfate-chloride in nature. These faces perhaps are derived from dissolution of calcium and magnesium carbonates.

\section{Materials and methods}

\section{Groundwater sampling and laboratory analysis}

Forty groundwater samples were collected, 20 each from deep and shallow aquifers. Groundwater samples were collected mainly from shallow wells and boreholes which are currently in use. Samples were drawn from water sources constructed by Kebbi State Government. Because these sources are expected to meet all the necessary requirements for water supply, physical parameters-temperature, $\mathrm{pH}$, $\mathrm{EC}$, and TDS - were determined in situ using water quality probes (Table 1). Probes were first calibrated by deionized water and then by water from shallow wells and boreholes. Discrete water samples were collected in 1-1 polyethylene bottles for determination of cations $\left(\mathrm{K}^{+}, \mathrm{Na}^{+}, \mathrm{Ca}^{2+}, \mathrm{Cu}^{2+}\right.$, $\mathrm{Fe}^{3+}, \mathrm{Zn}^{2+}$ and $\left.\mathrm{Mg}^{2+}\right)$ and anions $\left(\mathrm{Cl}^{-}, \mathrm{HCO}_{3}{ }^{-}, \mathrm{CO}_{3}{ }^{2-}\right.$, $\mathrm{PO}_{4}{ }^{3-}, \mathrm{NO}_{3}{ }^{-}$, and $\mathrm{SO}_{4}{ }^{2-}$ ). 
Table 1 Summary of field and laboratory methods

\begin{tabular}{|c|c|c|c|}
\hline Parameters & Methods & Description & Source \\
\hline \multicolumn{4}{|l|}{ Physical } \\
\hline Temperature & Field & Temp/salinity meter (DKMsG01) & Makoto et al. (2003) \\
\hline Conductivity & Field & Conductivity/TDS meter & Wali and Bakari (2016) and Wali et al. (2018a, b) \\
\hline $\mathrm{pH}$ & Field & $\mathrm{pH}$ meter (pHep) & Mondal et al. (2010) and Wali et al. (2018a, b) \\
\hline TDS & Field & Temp/salinity meter & Mondal et al. (2010) and Wali et al. (2018a, b) \\
\hline \multicolumn{4}{|l|}{ Cations } \\
\hline Potassium (mg/l) & Laboratory & AAS & EPA (2001) and Wali et al. (2018a, b) \\
\hline Sodium (mg/l) & Laboratory & AAS & EPA (2001) and Wali et al. (2018a, b) \\
\hline Calcium (mg/l) & Laboratory & AAS & EPA (2001) and Wali et al. (2018a, b) \\
\hline Copper (mg/l) & Laboratory & AAS & EPA (2001) and Wali et al. (2018a, b) \\
\hline Iron $(\mathrm{mg} / \mathrm{l})$ & Laboratory & AAS & EPA (2001) and Wali et al. (2018a, b) \\
\hline Zinc $(\mathrm{mg} / \mathrm{l})$ & Laboratory & AAS & EPA (2001) and Wali et al. (2018a, b) \\
\hline Magnesium (mg/l) & Laboratory & AAS & EPA (2001) and Wali et al. (2018a, b) \\
\hline \multicolumn{4}{|l|}{ Anions } \\
\hline Phosphate (mg/l) & Laboratory & $\mathrm{AC}$ & EPA (2001) and Wali et al. (2018a, b) \\
\hline Chloride (mg/l) & Laboratory & Titration & EPA (2001) and Wali et al. (2018a, b) \\
\hline Bicarbonate (mg/l) & Laboratory & Titration & EPA (2001) and Wali et al. (2018a, b) \\
\hline Nitrate $(\mathrm{mg} / \mathrm{l})$ & Laboratory & $\mathrm{AC}$ & EPA (2001) and Wali et al. (2018a, b) \\
\hline Chloride (mg/l) & Laboratory & $\mathrm{AC}$ & EPA (2001) and Wali et al. $(2018 a, b)$ \\
\hline Sulfate & Laboratory & $\mathrm{IC}$ & EPA (2001) and Wali et al. (2018a, b) \\
\hline
\end{tabular}

$A A S$ atomic absorption spectrometry, $A C$ automated colorimetry, $I C$ ion chromatography

Samples were stored in insulated containers less than $5{ }^{\circ} \mathrm{C}$. Prior to the collection of water samples, polyethylene bottles were washed twice; initially by using deionized water and then with the water from sampled boreholes and handdug shallow wells. Water samples were analyzed within $24 \mathrm{~h}$, and as a result, no acid treatment for samples was made. All analyses were carried out in triplicates, and results were found reproducible within \pm 5 error limit. Table 1 summarizes field and laboratory methodologies employed in this study.

Ions, including potassium, sodium, calcium, copper, iron, magnesium, and zinc, were analyzed using atomic absorption spectrometry. It is a method in which free gaseous atoms engross electromagnetic radiation at a specific wavelength to produce a calculable signal. The absorption of those free absorbing atoms in the optical path is proportional to the absorption signal (Fernández-Cirelli et al. 2009). Consequently, for AAS measurements, the analyte was first converted into gaseous atoms, typically by applying heat to a cell (i.e., atomizer). The nature of atomizer outlines the two main AAS-based analytical techniques: flame atomic absorption spectrometry (FAAS) that consistently offers analytical signals and electrothermal atomic absorption spectrometry (ETAAS) sending analytical signals in an intermittent mode (2-4/sample). In both approaches, liquid (or dissolved) samples are presented into the analyzer, as an aerosol as in the case of FAAS which is used in this study or as a fully marked low microliter volume in ETAAS (Fernández-Cirelli et al. 2009).

Monochromators, based on Czerny-Turner, Ebert, and Littrow designs are the most conventional wavelength selectors used in AAS. More recently, echelle optics is being fused to commercial AAS devices. The introduction of an echelle configuration in association with a powerful continuous lamp creates significant capabilities, for instance, analysis of the spectral background near the line and concurrent multi-elemental scrutiny (FernándezCirelli et al. 2009). The said ions were analyzed using Atomic Absorption Spectrophotometer (Model: Rs 12.5 Lakh/Piece). Nitrate and phosphate were analyzed using automated colorimetry (BluVisionTM discrete analyzer). In addition, sulfate concentration was analyzed using iron chromatography (Agilent 6890 Plus GC with FPD and 7683 Autosampler). Lastly, chloride, carbonate, and bicarbonate were determined by titration (Table 1). Table 2 presents the results of physicochemical composition of shallow and deep groundwater in the study area. Groundwater suitability for drinking was evaluated by comparing the results with World Health Organization 


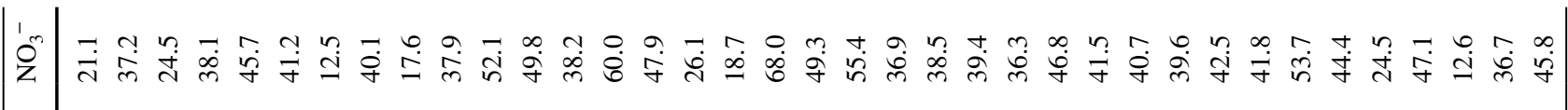

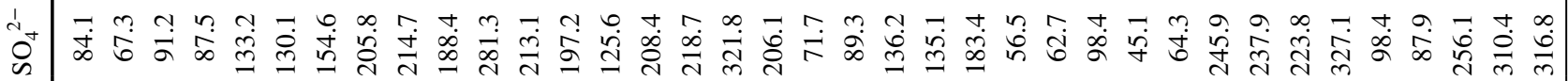

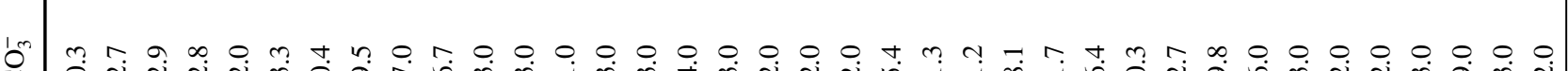
ర্য 少 䏒

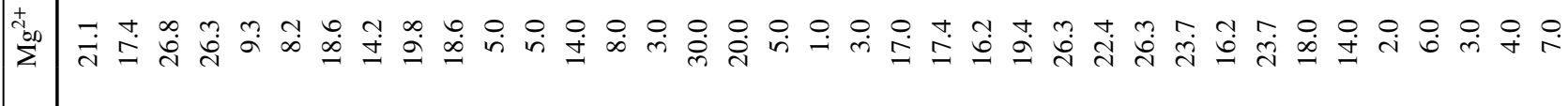
蛋 满 U ప (1)

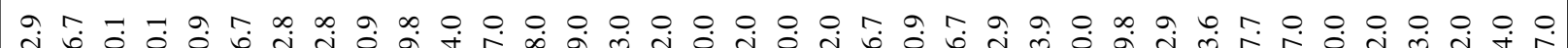
人

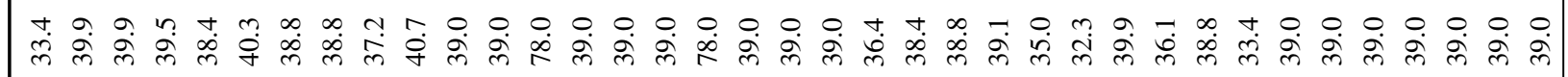

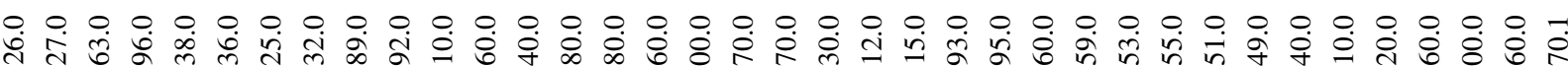
4ป ปิ

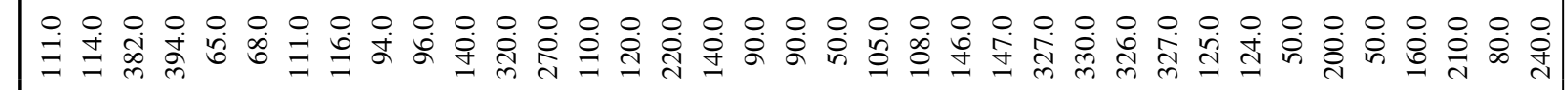

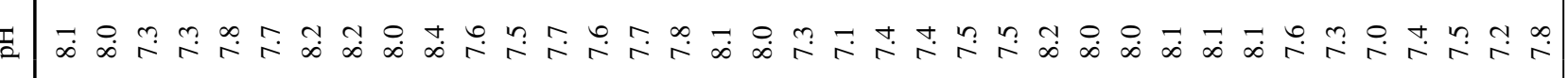

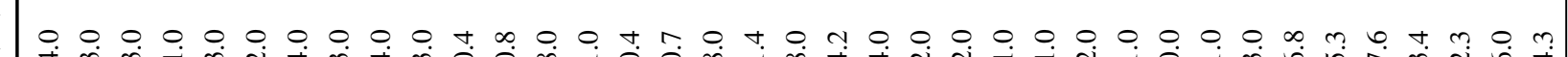
मे mं m लं $-$

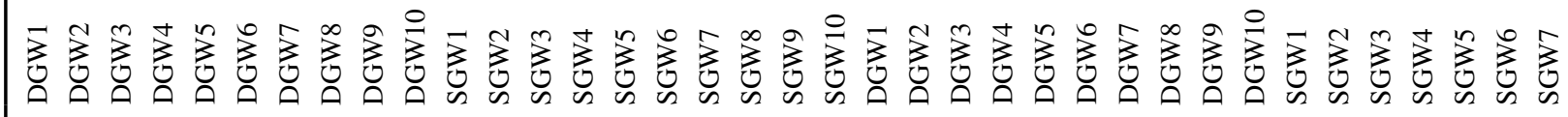


Table 3 Summary of chemical indices and analytical methods

\begin{tabular}{lll}
\hline Parameter & $\begin{array}{l}\text { Formula for calcula- } \\
\text { tion }\end{array}$ & Source \\
\hline $\begin{array}{l}\text { Molar ratio (MR) } \\
\text { Scholler index }(\mathrm{Si})\end{array}$ & $\mathrm{Na} / \mathrm{Cl}$ & Meybeck (1987) \\
$\begin{array}{l}\text { Total hardness } \\
\left(\mathrm{CaCO}_{3}\right)\end{array}$ & $2.5(\mathrm{Ca})+4.1(\mathrm{Mg})$ & Scholler (1965) \\
$\begin{array}{l}\text { Versluys index }(\mathrm{Vi}) \\
\mathrm{Na} /(\mathrm{Na}+\mathrm{Ca}+\mathrm{Mg})\end{array}$ & Versluys (1916) \\
\hline
\end{tabular}

(World Health Organization 2011) and Nigerian Standard for Drinking Water Quality (National Standard for Drinking Water Quality 2007) reference guidelines for drinking water quality (Table 2).

\section{Calculation of chemical indices}

Chemical indices, including $\mathrm{Ki}, \mathrm{Mg}$, MR, PI, RSC, Si, SAR, Na\% and Vi (Table 3), were also calculated to evaluate ion exchange, silicate weathering reactions. Also contained in the table is a formula for calculating total hardness.

\section{Statistical analysis}

Groundwater data were standardized and summarized using basic descriptive statistics: mean, minimum, maximum, and standard error (Table 4). Pearson's correlation ( $r$ ) was used to test the relationship between physical and chemical elements of groundwater following Margahde et al. (2011). Prior to this, a nonparametric test (Kruskal-Wallis) was used to test whether there is a significant difference in groundwater composition between shallow and deep groundwater sources, using several samples ANOVA (Table 4). This method allows for comparing several independent random samples and can be used as a nonparametric substitute to the one-way ANOVA (Cruz et al. 2019; Montcoudiol et al. 2019; Morris et al. 2019). The Kruskal-Wallis test statistic for $k$ samples, each of size $n_{i}$ is defined viz:

$T=\frac{1}{s^{2}}\left[\sum_{i=1}^{k} \frac{R_{i}}{n_{i}}-N \frac{(N+1)^{2}}{4}\right]$

where $N$ is the total number (all in) and $R_{i}$ is the sum of the ranks (from all samples drawn) for the $i$ th sample and:

$$
S^{2}=\frac{1}{N-1}=\left[\sum_{\text {all }} R_{i j}^{2}-N \frac{(N+1)^{2}}{4}\right]
$$


Table 4 Summary of physical and chemical properties of groundwater

\begin{tabular}{|c|c|c|c|c|c|c|c|c|c|c|c|c|c|}
\hline \multirow{2}{*}{$\begin{array}{l}\text { Param- } \\
\text { eter } \\
\text { Physical }\end{array}$} & \multicolumn{4}{|c|}{ Borehole (deep aquifer) } & \multicolumn{4}{|c|}{ Dug well (shallow aquifer) } & \multicolumn{2}{|c|}{ Reference guidelines } & \multicolumn{3}{|c|}{$\begin{array}{l}\text { Kruskal-Wallis } \\
\text { Nonparametric test }\end{array}$} \\
\hline & Mean & Min & Max & SE & $\overline{\text { Mean }}$ & Min & $\operatorname{Max}$ & SE & $\begin{array}{l}\text { National Stand- } \\
\text { ard for Drinking } \\
\text { Water Quality } \\
(2007)\end{array}$ & $\begin{array}{l}\text { World Health } \\
\text { Organization } \\
(2011)\end{array}$ & $\overline{H\left(\mathrm{chi}^{2}\right)}$ & $\begin{array}{l}\text { Hc (tie cor- } \\
\text { rected) }\end{array}$ & $p$ (same) \\
\hline$T\left({ }^{\circ} \mathrm{C}\right)$ & 32.4 & 30 & 34 & 5.4 & 26.8 & 21.4 & 31 & 4.9 & Ambient & Ambient & 27.1 & 27.4 & $<0.001 *$ \\
\hline $\mathrm{pH}$ & 7.9 & 7.3 & 8.4 & 1.3 & 7.4 & 6.8 & 8.1 & 1.3 & $6.5-8.5$ & $6.5-8.5$ & 9.8 & 9.9 & $0.002 * *$ \\
\hline TDS & 180.8 & 65 & 394 & 62.3 & 142 & 40 & 320 & 50.6 & 500 & 1000 & 0.9 & 0.9 & 0.330 \\
\hline $\mathrm{EC}$ & 363.3 & 136 & 796 & 125.9 & 95.5 & 10 & 260 & 41.1 & 1000 & 1400 & 21.2 & 21.2 & $<0.001 *$ \\
\hline $\mathrm{TH}$ & 76.2 & 19.4 & $184.9 * * *$ & 29.2 & 134.4 & 63.4 & 402.8 & 63.7 & 150 & 200 & 9.015 & 9.016 & $0.002 * *$ \\
\hline \multicolumn{14}{|l|}{ Cations } \\
\hline $\mathrm{K}^{+}$ & 37.7 & 32.3 & 40.7 & 6.4 & 42.9 & 39 & 78 & 12.3 & - & - & 4.0 & 4.4 & 0.036 \\
\hline $\mathrm{Na}^{+}$ & 3.9 & 0 & 9.8 & 1.5 & $449.9^{* * *}$ & 2 & $598 * * *$ & 94.6 & 12 & 200 & 25.3 & 25.4 & $<0.001$ \\
\hline $\mathrm{Ca}^{2+}$ & 21.9 & 2.7 & 129.3 & 20.4 & 19.7 & 1.2 & 51 & 8.1 & 500 & 75 & 1.3 & 1.3 & 0.256 \\
\hline $\mathrm{Cu}^{2+}$ & 0.3 & 0.1 & 0.6 & 0.1 & 0.6 & 0.1 & $1.6^{* * * *}$ & 0.3 & 1 & 1 & 1.4 & 1.4 & 0.238 \\
\hline $\mathrm{Fe}^{3+}$ & 0.9 & 0.1 & 3.1 & 0.5 & 1.6 & 0.5 & $2.7 * * *$ & 0.4 & 2 & 2 & 8.7 & 8.7 & $0.003 * *$ \\
\hline $\mathrm{Zn}^{2+}$ & 0.5 & 0.2 & 1 & 0.2 & $5.3 * * *$ & 2 & $8.4 * * *$ & 1.3 & 3 & 3 & 29.3 & 29.4 & $<0.001 *$ \\
\hline $\mathrm{Mg}^{2+}$ & $19.4 * * *$ & $8.2 * * *$ & $26.8 * * *$ & 4.2 & $6.6^{* * *}$ & 1 & $20 * * *$ & 3.2 & 0.20 & 125 & 22.7 & 22.7 & $<0.001 *$ \\
\hline \multicolumn{14}{|l|}{ Anions } \\
\hline $\mathrm{PO}_{4}{ }^{3-}$ & $0.4^{* * *} *$ & 0.1 & $0.6^{* * *}$ & 0.1 & $18.4^{* * * *}$ & $11 * * *$ & $23 * * *$ & 3.6 & 0.2 & 0.2 & 29.3 & 29.5 & $<0.001 *$ \\
\hline $\mathrm{Cl}^{-}$ & 2.5 & 0.6 & 3.5 & 0.6 & 188.8 & 4 & $888^{* * * *}$ & 140.4 & 200 & 250 & 29.3 & 29.4 & $<0.001 *$ \\
\hline $\mathrm{HCO}_{3}^{-}$ & 14 & 0.3 & 33.3 & 5.3 & $176.9^{* * *}$ & 61 & $549 * * * *$ & 86.8 & 250 & $125-130$ & 29.3 & 29.7 & $<0.001 *$ \\
\hline $\mathrm{SO}_{4}{ }^{2-}$ & 131.1 & 45.1 & $245.9 * * *$ & 38.9 & 206.3 & 67.5 & $327.1^{* * *}$ & 51.7 & 200 & 250 & 8.0 & 8.0 & $0.005^{*}$ \\
\hline $\mathrm{NO}_{3}^{-}$ & 36 & 12.5 & 46.8 & 7.4 & 42.7 & 12.6 & 45.2 & 7.1 & 50 & 50 & 5.2 & 5.2 & 0.022 \\
\hline
\end{tabular}

*** Do not follow WHO and/or NSDWQ reference guidelines

$*$ Significant difference between shallow and deep groundwater $<0001 ; * *$ significant difference between shallow and deep groundwater $\leq 0.005$

The null hypothesis of the test is that all $k$ distribution functions are equal. The alternative hypothesis is that at least one of the observations tends to yield larger values than at least one of the other observations (Cruz et al. 2019; Montcoudiol et al. 2019; Morris et al. 2019). Results obtained show that there was no significant difference in TDS, $\mathrm{K}^{+}$, $\mathrm{Ca}^{2+}$, and $\mathrm{Cu}^{2+}$ concentrations between shallow and deep groundwater.

\section{Principal component analysis}

One of the major multivariate statistical method used in the interpretation of water chemistry is principal component analysis (Ayoko et al. 2007; Miguntanna et al. 2010). The PCA which is multivariate statistical method is applied to reduce the size of hydrochemical data (Alias et al. 2014; Hildebrandt et al. 2008; Machiwal and Jha 2015; Yidana 2010; Yidana et al. 2018). Reduction of the analytical data of individual sampling location is the primary purpose of applying PCA. The PCA tends to be intercorrelated with a less important set of 'principal components' (PCs) which can be interpreted (Machiwal and Jha 2015). The PC group inter-related absorptions together and can be related to some geogenic processes or pollution from the anthropogenic sources.

Generally, PCA comprises of two steps: standardization of data and extraction of PCs (Machiwal and Jha 2015). While some related data on the variability may be lost via transformation, the explanation of the system is significantly abridged, and it can be envisaged to derive suitable evidence on the relationship between parameters and observations (Hildebrandt et al. 2008). The PCA bilinear model can be rearranged following the matrix decomposition equation (Hildebrandt et al. 2008), and thus,

$X=T P^{T}+E$

where $X$ represents a matrix of data which is compressed into $T$ (scores of matrices) and $P T$ (matrix of loadings), plus $E$ (matrix residual) (Hildebrandt et al. 2008). The extracted PCs in this study showed that groundwater in both shallow and deep aquifers are more influenced by the natural geogenic process as compared to human activities.

\section{Hierarchical cluster analysis}

The vital role of HCA is to discrete the parameters in a raw data matrix or PC scores into separate classes designated by 
the user without any prior hypotheses. The HCA is an unverified outline identification technique that reveals inherent assembly or recognizing the pattern of a dataset without a prior hypothesis with regard to the data so that the objects of the system can be classified into clusters based on their resemblances (Lin et al. 2012; Machiwal and Jha 2015). The HCA is a widely used method which can form clusters consecutively, beginning with the most identical pair of parameters and forming complex clusters after each step which is repeated until a single cluster comprising all the observations is attained (Lin et al. 2012; Machiwal and Jha 2015). In this study, the Ward's algorithmic gathering technique subsequent to the squared Euclidean distance was employed. This is measured as the most influential means of clustering (Lin et al. 2012; Machiwal and Jha 2015).

Before the clustering analysis, the detected hydrochemical data, $x_{j i}$, was standardized by $z$-scale transformation as given below (Machiwal and Jha 2015):

$Z=\frac{X_{j i-\dot{x}_{j}}}{S j}$

where $x_{j i}=$ value of the $j$ th hydrochemical parameter measured at the $i$ th location, $\dot{x}_{j}=$ mean (spatial) value of the $j$ th parameter and $S_{j}=$ standard deviation (spatial) of the $j$ th parameter (Machiwal and Jha 2015). The clustering achieved with standardized data is anticipated to be influenced less by the large and/or small variance of the hydrochemical data matrix. Also, the influence of diverse measurement units of the data can be removed by making the data dimensionless (Machiwal and Jha 2015). In this study, HCA was performed on a subset of 17 selected variables ( $\mathrm{pH}, \mathrm{EC}$, Temp., TDS, TH, $\mathrm{Ca}^{2+}, \mathrm{Mg}^{2+}, \mathrm{Na}^{+}, \mathrm{K}^{+}, \mathrm{Fe}^{3+}, \mathrm{Cu}^{2+}, \mathrm{Zn}^{2+}, \mathrm{CO}_{3}{ }^{2-}$, $\mathrm{HCO}_{3}{ }^{2-}, \mathrm{Cl}^{-}, \mathrm{NO}_{3}{ }^{-}, \mathrm{PO}_{4}{ }^{3-}$, and $\mathrm{SO}_{4}{ }^{2-}$ ), which represented the overall water chemistry outline. The HCA results are presented as a dendrogram (Fig. 10), which offers a graphic summary illustrating an image of the clusters and their closeness with an observed decrease in the dimensionality of original observations. This is measured as a good technique for presenting results of HCA (Lin et al. 2012; Machiwal and Jha 2015). This evidence allowed the construction of a dendrogram as a function of the water quality parameters and sampling locations. Therefore, applying raw data matrix into HCA is an excellent technique which helps classify hydrochemical data based on similarities of sampled parameters across the sampling sites.
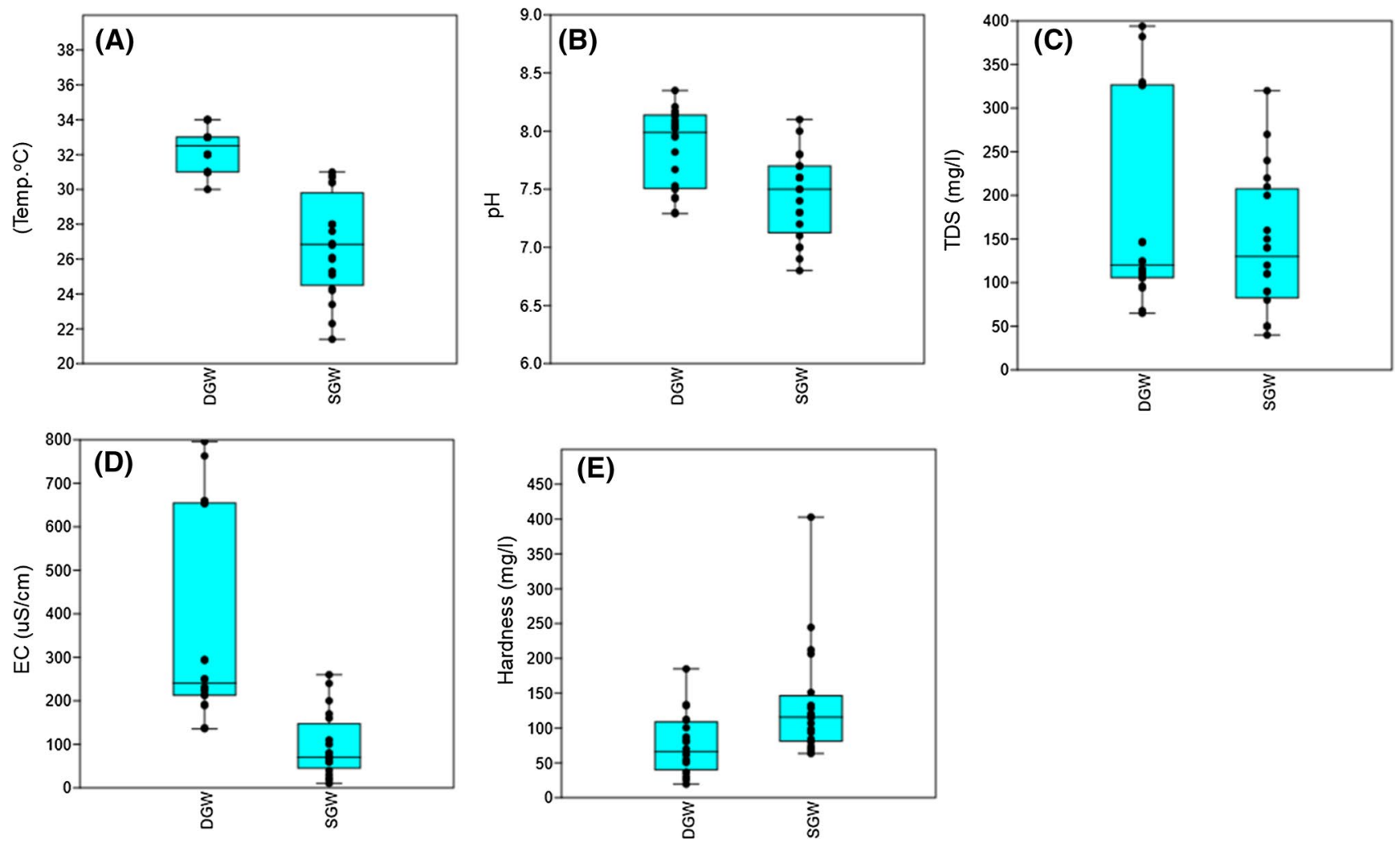

Fig. 5 Variability in physical parameters between deep and shallow groundwater a temperature; b pH; c EC, d TDS; and e hardness. $D G W$ deep groundwater, $S G W$ shallow groundwater 
Table 5 Groundwater classification based on TDS, hardness, and conductivity

\begin{tabular}{|c|c|c|c|c|c|}
\hline \multirow[t]{2}{*}{ Range } & \multirow[t]{2}{*}{ Classification } & \multirow{2}{*}{$\begin{array}{l}\text { No. of } \\
\text { Sam- } \\
\text { ples }\end{array}$} & \multirow[t]{2}{*}{$\%$ of samples } & \multicolumn{2}{|l|}{ Sample numbers } \\
\hline & & & & SGW & DGW \\
\hline \multicolumn{6}{|c|}{ (A) TDS (mg/l) } \\
\hline \multicolumn{6}{|c|}{ After David and De West (1966) } \\
\hline$<500$ & Required for drinking & 40 & 100 & $1-20$ & $1-20$ \\
\hline $500-1000$ & Acceptable for drinking & - & - & - & - \\
\hline $1000-3000$ & Suitable for drinking & - & - & - & - \\
\hline$>3000$ & $\begin{array}{l}\text { Unsuitable for drinking } \\
\text { and irrigation }\end{array}$ & - & - & - & - \\
\hline Total & & 40 & 100 & - & \\
\hline \multicolumn{6}{|c|}{$\begin{array}{l}\text { (B) Total hardness }\left(\mathrm{CaCO}_{3}\right) \\
\text { After Sawyer and McCarty (1967) }\end{array}$} \\
\hline$<75$ & Soft & 15 & 37.5 & F1, F5, F8, F9, F10; Z2-6, Z9, Z10 & F5, F6, F8; Z9 \\
\hline $75-150$ & Moderately hard & 21 & 52.5 & F2, F3, F4, F6, F7, Z1, Z5, Z7, Z8 & $\begin{array}{l}\text { F1, F4, F7, F9, F10; Z1, Z2, Z3, Z4, } \\
\text { Z5, Z6, Z7, Z8, Z10 }\end{array}$ \\
\hline $150-300$ & Hard & 3 & 7.5 & - & $\mathrm{F} 2, \mathrm{~F} 3, \mathrm{Z8}$ \\
\hline$>300$ & Very hard & 1 & 2.5 & - & $\mathrm{Z} 4$ \\
\hline \multicolumn{2}{|c|}{ After Richards (1954) } & & & & \\
\hline$<250$ & Excellent & 38 & 95 & $\begin{array}{l}\text { F1, F2, F3, F4, F5, F6, F7, F8, F9, } \\
\text { F10 }\end{array}$ & $\begin{array}{l}\text { F1, F2, F5, F6, F7, F8, F9, F19; Z1, Z2, } \\
\text { Z3, Z4, Z5, Z6, Z7, Z8, Z9, Z10 }\end{array}$ \\
\hline $250-250$ & Good & 2 & 5 & - & $\mathrm{F} 3, \mathrm{~F} 4$ \\
\hline $750-2000$ & Permissible & - & - & - & - \\
\hline $2000-3000$ & Doubtful & - & - & - & - \\
\hline$>3000$ & Unsuitable & - & - & - & - \\
\hline
\end{tabular}

$D G W$ deep groundwater, $S G W$ shallow groundwater

Table 6 Groundwater classification based on chloride and nitrate

\begin{tabular}{|c|c|c|c|c|c|}
\hline \multirow[t]{2}{*}{ Class } & \multirow[t]{2}{*}{ Range } & \multirow{2}{*}{$\begin{array}{l}\text { Number } \\
\text { of sam- } \\
\text { ples }\end{array}$} & \multirow[t]{2}{*}{$\%$ of samples } & \multicolumn{2}{|l|}{ Sample number } \\
\hline & & & & DGW & SGW \\
\hline \multicolumn{6}{|c|}{$\begin{array}{l}\text { (A) Chloride (mg/l) } \\
\text { After Stuyfzand (1989) }\end{array}$} \\
\hline Extremely fresh & $<0.14$ & 0 & 0 & 0 & 0 \\
\hline Very fresh & $0.14-0.85$ & 0 & 0 & 0 & 0 \\
\hline Fresh & $0.85-4.23$ & 30 & 75 & $\begin{array}{l}\text { F1, F2, F3, F4, F5, F6, F7, F8, F9, F10; } \\
\text { Z1, Z2, Z3, Z4, Z5, Z6, Z7, Z8, Z9, } \\
\text { Z10 }\end{array}$ & $\begin{array}{l}\text { F1, F2, F3, F4, F5, F6, F7, F8, F9, } \\
\text { F10 }\end{array}$ \\
\hline Fresh brackish & $4.23-8.46$ & 1 & 2.5 & 0 & $\mathrm{Z} 4$ \\
\hline Brackish & $8.46-28.21$ & 0 & 0 & 0 & 0 \\
\hline Brackish salt & $28.21-546.13$ & 9 & 22.5 & 0 & Z1, Z2, Z3, Z5, Z6, Z7, Z8, Z9, Z10 \\
\hline Hypersaline & $>564.13$ & 0 & 0 & 0 & 0 \\
\hline \multicolumn{6}{|l|}{ (B) Nitrate (mg/l) } \\
\hline Acceptable & $<5$ & 0 & 0 & 0 & 0 \\
\hline Moderate & $5-30$ & 9 & 22.5 & F1, F3, F7, F9 & F6, F7; Z3, Z5, Z9 \\
\hline Severe & $>30$ & 31 & 77.5 & $\begin{array}{l}\text { F2, F4, F5, F6, F8, F10; Z1, Z2, Z3, Z4, } \\
\quad \text { Z5, Z6, Z7, Z8, Z9, Z10 }\end{array}$ & $\begin{array}{l}\text { F1, F2, F3, F4, F5, F8, F9, F10; Z1, } \\
\text { Z2, Z3, Z4, Z6, Z7, Z8 }\end{array}$ \\
\hline
\end{tabular}

$D G W$ deep groundwater, $S G W$ shallow groundwater 


\section{Results and discussion}

\section{Suitability for drinking}

Table 4 summarizes the physicochemical composition of groundwater obtained from boreholes and hand-dug shallow wells. Groundwater composition between the two sources showed a marked variability between the shallow and deep groundwater sources. Groundwater temperature varies significantly $(H=27.36, p=<0.001)$ between shallow and deep aquifers. Temperature variability can be very critical especially where biochemical reactions are concerned. Because an increase in temperature by $10{ }^{\circ} \mathrm{C}$ in groundwater aquifer leads to doubling of chemical reactions (EPA 2001), the solubility of gasses, ion exchange capacity, redox reaction, sorption processes, complexation, speciation, EC and $\mathrm{pH}$ level are all affected by variations in temperature (Ngabirano et al. 2016).

Similarly, $\mathrm{pH}$ differs significantly $(H=9.86, p=0.002)$ between the two sources of groundwater. Groundwater is slightly acidic to alkaline in the study area. While $\mathrm{pH}$ has less effect on consumers, it is fundamental to understanding the chemical composition of groundwater. Moderate $\mathrm{pH}$ level is required depending on the composition of groundwater and aquifer properties (EPA 2001). No significant difference in TDS concentration $(H=0.94, p=0.33)$, but EC levels differ significantly $(H=21.15, p=<0.001)$
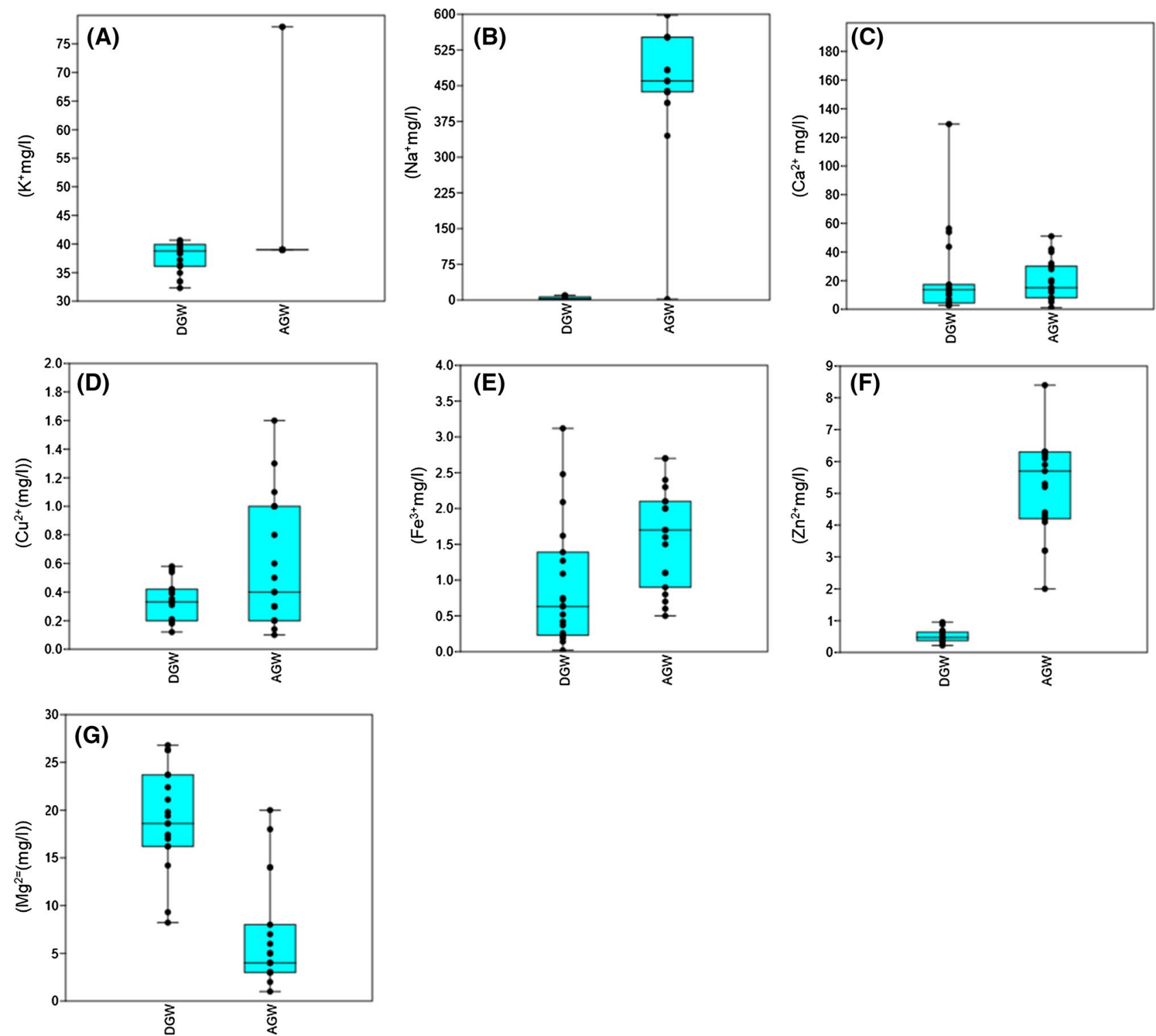

Fig. 6 Variability of cations a potassium; $\mathbf{b}$ sodium; $\mathbf{c}$ calcium; $\mathbf{d}$ copper; $\mathbf{e}$ iron; $\mathbf{f}$ zinc; and $\mathbf{g}$ magnesium 
between deep and shallow groundwater. Overall, the physical composition of groundwater in the study area indicates water of excellent quality for drinking. Mean $\mathrm{pH}$, TDS, and EC are within World Health Organization (2011) and National Standard for Drinking Water Quality (2007) reference guidelines. Figure 5 illustrates the variability of physical parameters of groundwater in the study area.

\section{Groundwater classification base on TDS, EC, and TH}

Table 5 presents the groundwater classification based on TDS, TH, and EC. All the groundwater samples obtained from deep and shallow groundwater sources have TDS concentrations $<500 \mathrm{mg} / \mathrm{l}$. This is especially required for drinking (David and DeWest 1966). Low TDS concentrations have been reported elsewhere in Sokoto Basin (along the Sokoto-Gusau road). Groundwater sources in this area have low TDS-28-79 mg/l (Anderson and Ogilbee 1973; Uma 1993; Alagbe 2006). Groundwater hardness also differs significantly between deep and shallow groundwater $(H=9.015, p=<0.005)$. Further, classification base on hardness showed that most of the groundwater sources are moderately hard (Table 5). Current result concurs with previous reports on hardness in Sokoto Basin. Groundwater obtained from the Rima Group is moderately hard to hard in nature (Anderson and Ogilbee 1973; Uma 1993; Alagbe
2006). Groundwater classification based on EC showed that 95\% of water sources fall in excellent class and $5 \%$ fall in a good class. The relatively low EC levels in the study area are consequent of low TDS, which is generally low in Sokoto Basin.

\section{Groundwater classification base on chloride and nitrate}

Table 6 presents the groundwater classification based on chloride and nitrate pollution in the study area. Based on chloride $75 \%$ of water samples fall in fresh class (i.e., $0.85-4.23 \mathrm{mg} \mathrm{Cl}$ ), $22.5 \%$ fall in brackish salt class (i.e., $28.21-546.13 \mathrm{mg} \mathrm{Cl}$ ) and $2.5 \%$ fall in fresh brackish salt (i.e., $4.23-8.46 \mathrm{mg} \mathrm{Cl}$ ). However, based on nitrate pollution, $22.5 \%$ fall in moderate class (i.e., $5-30 \mathrm{mg} \mathrm{NO}_{3}$ ) and $77.5 \%$ fall in severe class (i.e. $>30 \mathrm{mg} \mathrm{NO}_{3}$ ). Since $\mathrm{NO}_{3}{ }^{-}$is mainly derived from the oxidation of ammonia and agricultural fertilizer, the observed high $\mathrm{NO}_{3}{ }^{-}$levels in both shallow and deep aquifer is perhaps consequent agriculture and/or other human activities (changes in land use, sewage), but new studies are required for further evaluation. Mean $\mathrm{NO}_{3}{ }^{-}$concentration is below $50 \mathrm{mg} / \mathrm{l}$ in both shallow and deep groundwater. This is an expected outcome since Basement Complex areas are often characterized by one-aquifer system. Therefore, effluents collected in shallow groundwater are transported to deeper groundwater reservoirs.
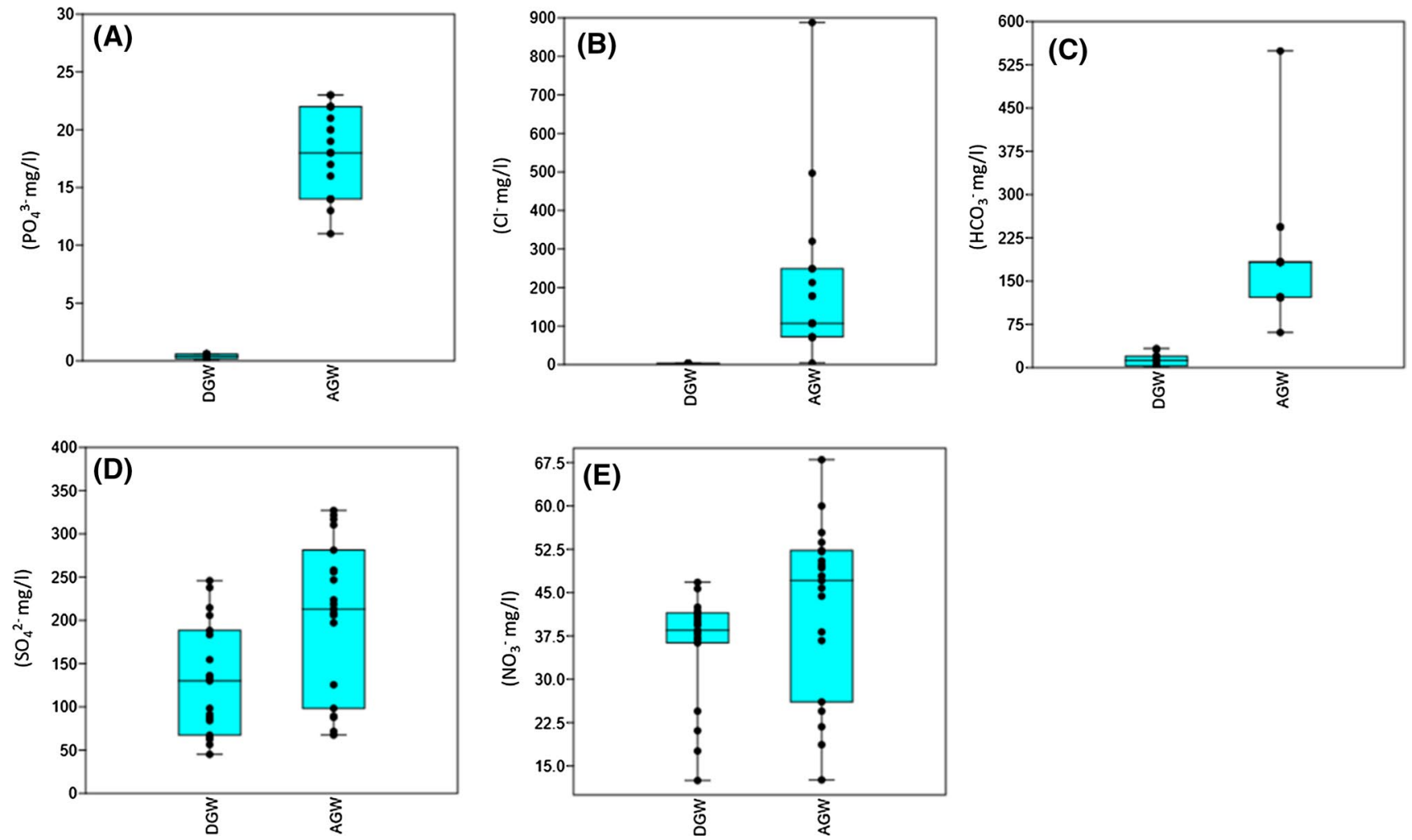

Fig. 7 Variability of anions a phosphate; $\mathbf{b}$ chloride; $\mathbf{c}$ bicarbonate; $\mathbf{d}$ sulfate; $\mathbf{e}$ iron; and $\mathbf{f}$ nitrate 
Elevated $\mathrm{NO}_{3}{ }^{-}$levels in drinking water $(>50 \mathrm{mg} / \mathrm{l})$ can be dangerous to infants-blue baby syndrome (EPA 2001; Wali et al. 2018a, b).

\section{The cation chemistry}

Figure 6 shows the variability in $\mathrm{K}^{+}, \mathrm{Na}^{+}, \mathrm{Ca}^{2+}, \mathrm{Cu}^{2+}, \mathrm{Fe}^{3+}$, $\mathrm{Zn}^{2+}$, and $\mathrm{Mg}^{2+}$ concentrations between shallow and deep groundwater in the study area. Potassium concentration differs significantly $(H=4.41, p=<0.005)$ between deep and shallow groundwater (Table 4$)$. Elevated $\mathrm{K}^{+}$level in groundwater is associated with toxicity. $\mathrm{K}^{+}$in most aquifers is found in low concentrations and excessive intake is not associated with any health hazard (EPA 2001). Sodium concentration differs significantly $(H=25.41, p=<0.001) . \mathrm{Na}^{+}$ is regulated in drinking water because of the joint effects it exercises with sulfate. High consumption is associated with hypertension (EPA 2001). $\mathrm{Na}^{+}$absorption in an aquifer is dependent on the temperature of the solution and the associated anion. No significant difference in calcium concentration $(H=1.29, p=0.25)$. Elevated $\mathrm{Ca}^{2+}$ level is often associated with hardness.

Table 7 Correlation matrix of physicochemical parameters of deep groundwater

\begin{tabular}{|c|c|c|c|c|c|c|c|c|c|c|c|c|c|c|c|c|}
\hline Para. & $T\left({ }^{\circ} \mathrm{C}\right)$ & $\mathrm{pH}$ & TDS & EC & $\mathrm{K}^{+}$ & $\mathrm{Na}^{+}$ & $\mathrm{Ca}^{2+}$ & $\mathrm{Cu}^{2+}$ & $\mathrm{Fe}^{3+}$ & $\mathrm{Zn}^{2+}$ & $\mathrm{Mg}^{2+}$ & $\mathrm{PO}_{4}{ }^{3-}$ & $\mathrm{Cl}^{-}$ & $\mathrm{HCO}_{3}^{-}$ & $\mathrm{SO}_{4}^{2-}$ & $\overline{\mathrm{NO}_{3}{ }^{-}}$ \\
\hline$T\left({ }^{\circ} \mathrm{C}\right)$ & 1 & & & & & & & & & & & & & & & \\
\hline $\mathrm{pH}$ & 0.13 & 1 & & & & & & & & & & & & & & \\
\hline TDS & 0.17 & 0.39 & 1 & & & & & & & & & & & & & \\
\hline $\mathrm{EC}$ & 0.24 & 0.46 & 0.85 & 1 & & & & & & & & & & & & \\
\hline $\mathrm{K}^{+}$ & 0.14 & 0.43 & 0.27 & 0.35 & 1 & & & & & & & & & & & \\
\hline $\mathrm{Na}^{+}$ & 0.28 & 0.07 & -0.15 & -0.22 & 0.22 & 1 & & & & & & & & & & \\
\hline $\mathrm{Ca}^{2+}$ & 0.08 & 0.48 & 0.75 & 0.86 & 0.40 & -0.26 & 1 & & & & & & & & & \\
\hline $\mathrm{Cu}^{2+}$ & 0.14 & 0.11 & -0.09 & 0.00 & -0.22 & 0.40 & -0.02 & 1 & & & & & & & & \\
\hline $\mathrm{Fe}^{3+}$ & 0.25 & -0.20 & -0.22 & -0.31 & -0.40 & 0.25 & -0.21 & 0.63 & 1 & & & & & & & \\
\hline $\mathrm{Zn}^{2+}$ & -0.40 & -0.21 & -0.21 & -0.15 & 0.01 & 0.16 & -0.18 & -0.16 & -0.28 & 1 & & & & & & \\
\hline $\mathrm{Mg}^{2+}$ & 0.05 & 0.46 & 0.14 & 0.04 & 0.65 & 0.13 & 0.11 & -0.37 & -0.44 & 0.01 & 1 & & & & & \\
\hline $\mathrm{PO}_{4}^{3-}$ & 0.03 & 0.42 & -0.10 & -0.02 & 0.34 & 0.04 & 0.17 & 0.09 & -0.12 & -0.43 & 0.15 & 1 & & & & \\
\hline $\mathrm{Cl}^{-}$ & 0.13 & 0.37 & 0.57 & 0.63 & 0.59 & 0.40 & 0.65 & 0.06 & -0.25 & 0.09 & 0.32 & 0.077 & 1 & & & \\
\hline $\mathrm{HCO}_{3}^{-}$ & -0.19 & 0.10 & 0.21 & 0.31 & -0.19 & -0.89 & 0.32 & -0.15 & -0.22 & -0.22 & -0.18 & 0.121 & -0.40 & 1 & & \\
\hline $\mathrm{SO}_{4}^{2-}$ & 0.01 & 0.33 & 0.26 & 0.20 & 0.21 & -0.19 & 0.03 & -0.04 & -0.25 & -0.10 & 0.42 & -0.03 & 0.14 & 0.08 & 1 & \\
\hline $\mathrm{NO}_{3}{ }^{-}$ & -0.01 & 0.04 & -0.12 & -0.18 & -0.33 & 0.36 & -0.23 & -0.03 & 0.00 & -0.06 & -0.06 & 0.079 & 0.07 & -0.44 & -0.29 & 1 \\
\hline
\end{tabular}

Values in bold are significant at $\geq 0.50$

Table 8 Correlation matrix of physicochemical parameters of shallow groundwater

\begin{tabular}{|c|c|c|c|c|c|c|c|c|c|c|c|c|c|c|c|c|}
\hline Para. & $T\left({ }^{\circ} \mathrm{C}\right)$ & $\mathrm{pH}$ & TDS & EC & $\mathrm{K}^{+}$ & $\mathrm{Na}^{+}$ & $\mathrm{Ca}^{2+}$ & $\mathrm{Cu}^{2+}$ & $\mathrm{Fe}^{3+}$ & $\mathrm{Zn}^{2+}$ & $\mathrm{Mg}^{2+}$ & $\mathrm{PO}_{4}^{3-}$ & $\mathrm{Cl}^{-}$ & $\mathrm{HCO}_{3}^{-}$ & $\mathrm{SO}_{4}^{2-}$ & $\mathrm{NO}_{3}^{-}$ \\
\hline$T\left({ }^{\circ} \mathrm{C}\right)$ & 1 & & & & & & & & & & & & & & & \\
\hline $\mathrm{pH}$ & 0.12 & 1 & & & & & & & & & & & & & & \\
\hline TDS & -0.56 & -0.23 & 1 & & & & & & & & & & & & & \\
\hline $\mathrm{EC}$ & -0.56 & -0.23 & 1.00 & 1 & & & & & & & & & & & & \\
\hline $\mathrm{K}^{+}$ & -0.10 & -0.26 & -0.13 & -0.13 & 1 & & & & & & & & & & & \\
\hline $\mathrm{Na}^{+}$ & 0.01 & 0.29 & -0.27 & -0.27 & 0.21 & 1 & & & & & & & & & & \\
\hline $\mathrm{Ca}^{2+}$ & -0.24 & -0.26 & 0.09 & 0.09 & 0.12 & -0.13 & 1 & & & & & & & & & \\
\hline $\mathrm{Cu}^{2+}$ & -0.16 & 0.05 & 0.06 & 0.06 & 0.46 & 0.23 & -0.24 & 1 & & & & & & & & \\
\hline $\mathrm{Fe}^{3+}$ & 0.23 & -0.39 & -0.16 & -0.16 & -0.48 & -0.10 & -0.06 & -0.27 & 1 & & & & & & & \\
\hline $\mathrm{Zn}^{2+}$ & -0.14 & -0.64 & 0.60 & 0.60 & 0.30 & -0.23 & 0.20 & 0.14 & -0.05 & 1 & & & & & & \\
\hline $\mathrm{Mg}^{2+}$ & -0.28 & -0.02 & 0.80 & 0.80 & -0.31 & -0.09 & 0.13 & -0.35 & -0.20 & 0.42 & 1 & & & & & \\
\hline $\mathrm{PO}_{4}^{3-}$ & -0.02 & -0.15 & -0.30 & -0.29 & -0.14 & -0.24 & 0.26 & -0.11 & 0.19 & -0.14 & -0.32 & 1 & & & & \\
\hline $\mathrm{Cl}^{-}$ & 0.04 & 0.03 & -0.09 & -0.09 & 0.10 & 0.20 & -0.15 & 0.04 & 0.01 & -0.17 & -0.17 & -0.38 & 1 & & & \\
\hline $\mathrm{HCO}_{3}^{-}$ & -0.04 & 0.34 & -0.24 & -0.24 & -0.25 & 0.16 & -0.27 & 0.42 & -0.09 & -0.48 & -0.33 & 0.03 & -0.01 & 1 & & \\
\hline $\mathrm{SO}_{4}^{2-}$ & 0.38 & 0.30 & -0.56 & -0.56 & 0.01 & 0.11 & -0.47 & 0.08 & -0.03 & -0.36 & -0.39 & -0.19 & -0.02 & 0.34 & 1 & \\
\hline $\mathrm{NO}_{3}^{-}$ & -0.61 & -0.03 & 0.13 & 0.13 & -0.02 & 0.27 & -0.04 & 0.27 & 0.10 & -0.14 & -0.15 & -0.16 & 0.41 & 0.19 & -0.06 & 1 \\
\hline
\end{tabular}

Values in bold are significant at $\geq 0.50$ 
There is no significant difference in $\mathrm{Cu}^{2+}$ concentration $(H=1.39, p=0.23)$. Unpleasant tastes can occur at levels above $1 \mathrm{mg} / \mathrm{l}$ (EPA 2001). High $\mathrm{Cu}^{2+}$ ingestion in drinking water is not harmful to humans, and therapeutic doses of $\sim 20 \mathrm{mg} / \mathrm{l}$ are occasionally permitted (EPA 2001). There is a significant difference in $\mathrm{Fe}^{+}$concentration $(H=8.7$, $p=0.003$ ). Elevated $\mathrm{Fe}^{3+}$ levels in water can be injurious to aquatic animals even though the degree of noxiousness can be reduced by the interactions between other elements. Zinc differs significantly $(H=29.37, p=<0.001)$ between the two aquifers. At concentrations level of about $4 \mathrm{mg} / \mathrm{l}$, the unfriendly taste can occur (EPA 2001). At levels between 3 and $5 \mathrm{mg} / \mathrm{l}$, water might look opalescent and can form an oily film when boiled. There was a significant difference in $\mathrm{Mg}^{2+}$ concentration $(H=22.74, p=<0.001)$. The significance of $\mathrm{Mg}^{+}$in drinking water is that magnesium is the second major constituent of hardness $\left(\mathrm{CaCO}_{3}\right)$ (EPA 2001).

\section{Anion chemistry}

Figure 7 shows variability in $\mathrm{PO}_{4}{ }^{3-}, \mathrm{Cl}^{-}, \mathrm{HCO}_{3}{ }^{-}$, $\mathrm{SO}_{4}{ }^{2-}$ and $\mathrm{NO}_{3}{ }^{-}$between deep and shallow groundwater in the study area. There is a significant difference in $\mathrm{PO}_{4}{ }^{3-}$ concentration $(H=29.48, p=<0.001)$. The relevance of $\mathrm{PO}_{4}{ }^{3-}$ is mainly related to the rate of eutrophication in surface water bodies (EPA 2001). Chloride differs significantly $(H=29.39, p=<0.001)$. $\mathrm{Cl}^{-}$vary widely in natural waters, reaching a maximum level of $\sim 35,000 \mathrm{mg} / \mathrm{l}$. Excessive intake does not constitute a health hazard to humans, but at levels above $250 \mathrm{mg} / 1$ water will taste salty (EPA 2001). Chloride concentrations $\sim 2000 \mathrm{mg} / \mathrm{l}$ in drinking water is consumed in arid and semiarid regions. However, elevated $\mathrm{Cl}^{-}$levels in freshwater may render it unfit for irrigation use (EPA 2001). What is important is understanding in a sequence of outcomes from aquifers is that $\mathrm{Cl}^{-}$values are not absolute, rather the relative levels from one sampling point to another. Elevated $\mathrm{Cl}^{-}$levels of $\sim 5 \mathrm{mg} / \mathrm{l}$ at one location in comparison with other sampling points might lead to the suspicion of groundwater contamination from sewage ejection, especially if ammonia levels are also elevated (EPA 2001). Bicarbonate differs significantly $(H=29.74$, $p=<0.001) . \mathrm{HCO}_{3}{ }^{-}$in conjunction with $\mathrm{Ca}^{2+}$ and $\mathrm{Mg}^{2+}$ forms carbonate hardness. When groundwater designates high $\mathrm{pH}$ concentrations, it can be a sign of high content of carbonate and bicarbonate ions (EPA 2001). Sulfate concentrations differ significantly $(H=7.99, p=0.004)$. High $\mathrm{SO}_{4}{ }^{2-}$ in drinking water is associated with the emetic effect, particularly when joint together with $\mathrm{Mg}^{+}$or $\mathrm{Na}^{+}$. Nitrate concentration differs significantly $(H=5.22$,
Table 9 Calculated chemical indices for evaluating rock weathering process

\begin{tabular}{llllllll}
\hline Source type & \multicolumn{2}{l}{ Deep groundwater } & & Source type & \multicolumn{2}{l}{ Shallow groundwater } \\
\cline { 2 - 4 } \cline { 6 - 8 } & Si & Vi & MR & & Si & Vi & MR \\
\hline DGW1 & 12.8 & 0.1 & 12.8 & SGW1 & 6.4 & 1.0 & 5.8 \\
DGW2 & 13.4 & 0.1 & 13.4 & SGW2 & 1.5 & 0.9 & 1.4 \\
DGW3 & 15.6 & 0.0 & 15.6 & SGW3 & 0.8 & 0.9 & 0.7 \\
DGW4 & 18.5 & 0.0 & 18.5 & SGW4 & 2.2 & 0.9 & 2.1 \\
DGW5 & 13.8 & 0.0 & 13.8 & SGW5 & 7.3 & 1.0 & 6.7 \\
DGW6 & 18.9 & 0.2 & 18.9 & SGW6 & 2.4 & 0.9 & 2.2 \\
DGW7 & 30.8 & 0.1 & 30.8 & SGW7 & 3.0 & 0.9 & 2.6 \\
DGW8 & 13.4 & 0.1 & 13.4 & SGW8 & 2.4 & 1.0 & 2.2 \\
DGW9 & 24.8 & 0.0 & 24.8 & SGW9 & 4.7 & 1.0 & 4.3 \\
DGW10 & 20.9 & 0.3 & 20.9 & SGW10 & 5.5 & 1.0 & 5.2 \\
DGW11 & 16.4 & 0.2 & 16.4 & SGW11 & 4.4 & 0.9 & 4.1 \\
DGW12 & 15.2 & 0.0 & 15.2 & SGW12 & 4.7 & 1.0 & 4.3 \\
DGW13 & 19.9 & 0.2 & 19.9 & SGW13 & 8.2 & 1.0 & 7.7 \\
DGW14 & 20.1 & 0.0 & 20.1 & SGW14 & 7.4 & 1.0 & 6.8 \\
DGW15 & 13.4 & 0.1 & 13.4 & SGW15 & 10.3 & 0.0 & 0.5 \\
DGW16 & 11.2 & 0.0 & 11.2 & SGW16 & 4.2 & 1.0 & 3.9 \\
DGW17 & 15.2 & 0.2 & 15.2 & SGW17 & 1.0 & 0.9 & 0.9 \\
DGW18 & 61.9 & 0.0 & 61.9 & SGW18 & 5.4 & 0.9 & 4.9 \\
DGW19 & 12.2 & 0.2 & 12.2 & SGW19 & 4.4 & 1.0 & 4.1 \\
DGW20 & 19.3 & 0.2 & 19.3 & SGW20 & 2.9 & 1.0 & 2.7 \\
\hline
\end{tabular}

$S i$ Scholler index, $V i$ Versluy's index, $M R$ molar ratio 
$p=0.02)$. High $\mathrm{NO}_{3}{ }^{-}$in groundwater lead to suspicion of past anthropogenic pollution or high application of composts slurries feast over the land and inorganic fertilizers (EPA 2001).

\section{Mechanisms controlling water chemistry}

\section{Geochemical facies}

The origin of groundwater and the process which control groundwater chemistry is understood by the relationships between dissolved elements (Tables 7, 8). It is assumed that a sizable portion of $\mathrm{HCO}_{3}{ }^{-}$in aquifers originate from the dissolution of carbonate rocks by means of the action of infiltrating rainwaters enriched in $\mathrm{CO}_{2}$. A Ca$\mathrm{HCO}_{3}{ }^{-}$water type is produced when $\mathrm{CO}_{2}$ is released into solution by the dissolution of carbonate (Marghade et al. 2010). $\mathrm{HCO}_{3}{ }^{-}$and $\mathrm{Ca}^{2+}$ were positively correlated in shallow groundwater $(r=0.32)$, suggesting that calcite rocks were a source of $\mathrm{Ca}^{2+}$. The negative correlation between these ions in the deep aquifer $(r=-0.27)$ suggests that $\mathrm{Ca}^{2+}$ was not exclusively derived from calcite mineral. Other sources of $\mathrm{Ca}^{2+}$ in groundwater aquifers are apatite, dolomite, fluorite, gypsum, limestone, and marble. A weak positive correlation between $\mathrm{Ca}^{2+}$ and $\mathrm{SO}_{4}{ }^{2-}(r=0.03)$ perhaps indicates that some parts of $\mathrm{Ca}^{2+}$ in shallow groundwater is perhaps derived from gypsum. The negative correlation between these ions in deep

Table 10 Geochemical characterization of groundwater samples

\begin{tabular}{lllll}
\hline $\begin{array}{l}\text { Geochemical } \\
\text { facies }\end{array}$ & Characterization of groundwater quality & Water samples & No. of sam- \\
\cline { 3 - 4 } ples of samples
\end{tabular}

Fig. 8 Piper diagram showing the chemical composition of shallow and deep groundwater
EXPLANATION
1. $\mathrm{Ca}-\mathrm{Mg}-\mathrm{HCO}_{3}$
2. $\mathrm{Na}-\mathrm{HCO}_{3}$
3. $\mathrm{Na}-\mathrm{Cl}-\mathrm{SO}_{4}$
4. $\mathrm{Ca}-\mathrm{Mg}-\mathrm{SO}_{4}-\mathrm{Cl}$
5. $\mathrm{Ca}-\mathrm{Cl}$
6. $\mathrm{Na}-\mathrm{HCO}_{3}$
A. Ca-type
B. Nodominant
C. Mg-type
D. $\mathrm{HCO}_{3}$-type
E. $\mathrm{SO}_{4}$-type
F. Cl-type

100

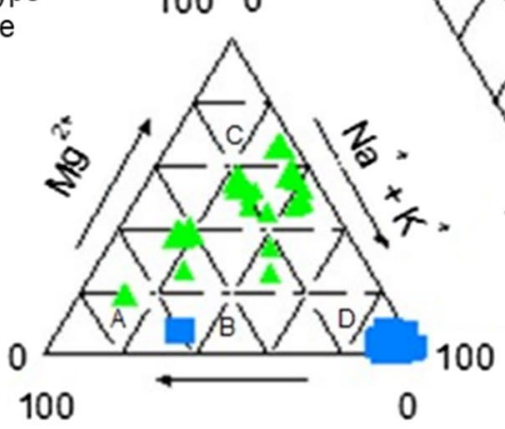

$\mathrm{Ca}^{2+}$

CATIONS
Borehole

Dug well 
aquifer suggests that $\mathrm{Ca}^{2+}$ did not derive from gypsum. TDS correlates significantly with $\mathrm{EC}, \mathrm{Ca}^{2+}$, and $\mathrm{Cl}^{-}$in shallow groundwater and was significantly correlated with $\mathrm{Zn}^{2+}$ and $\mathrm{Mg}^{2+}$ in deep groundwater. Significant correlations between TDS and these ions suggest that large parts of the dissolved solids in the study area are derived from these ions.

Weak correlation between $\mathrm{HCO}_{3}{ }^{-}$and $\mathrm{Ca}^{2+}(r=0.32)$ in shallow groundwater and negative correlation $(r=-0.27)$, between these ions in deep groundwater, suggest that dissolution of gypsum may not be the source of $\mathrm{Ca}^{2+}$ and $\mathrm{SO}_{4}{ }^{2-}$. Chloride correlates positively but weakly with $\mathrm{Na}^{+}$in both shallow $(r=0.40)$ and deep groundwater $(r=0.20)$. Positive correlations between these two ions suggest that some parts of $\mathrm{Na}^{+}$in the study area are derived from halite (Marghade et al. 2010).

Poor correlations ( $r=0.11, r=0.13)$, between $\mathrm{Ca}^{2+}$ and $\mathrm{Mg}^{2+}$ in both shallow and deep groundwater, suggest that the two ions might not have the same source. $\mathrm{SO}_{4}{ }^{2-}$ and $\mathrm{Mg}^{2+}$ were positively correlated in shallow groundwater $(r=0.40)$, suggesting that the two ions might likely have the same origin. But deep groundwater the two ions were negatively correlated $(r=-0.36)$, indicative that $\mathrm{SO}_{4}{ }^{2-}$ and $\mathrm{Mg}^{2+}$ are not derived from the same source. A charge equilibrium occurs between cations and anions when $\mathrm{Ca}^{2+}, \mathrm{Mg}^{2+}, \mathrm{SO}_{4}{ }^{2-}$, and $\mathrm{HCO}_{3}{ }^{-}+\mathrm{SO}_{4}{ }^{2-}$ originate from the simple dissolution of gypsum, dolomite, and calcite (Marghade et al. 2010).

\section{Silicate weathering and ion exchange process}

Silicate weathering reaction in the study area was evaluated using the $\mathrm{Na}^{+} / \mathrm{Cl}^{-}$molar ratio (Table 9). About $55 \%$ of the analyzed water samples from deep groundwater sources have a molar ratio greater than 1 , whereas $85 \%$ of water samples from shallow aquifer have a molar ratio greater than 1 . This suggests that some parts of $\mathrm{Na}^{+}$were derived from silicate weathering. However, the process of cation exchange $\mathrm{Ca}^{2+}$, $\mathrm{Mg}^{2+}$, and $\mathrm{Na}^{+}$may produce higher levels of $\mathrm{Na}^{+}$. When groundwater samples have a molar ratio greater than 1 , it indicates deficiency in $\mathrm{Mg}^{2+}+\mathrm{Ca}^{2+}$ which is equivalent to $\mathrm{Ca}^{2+}-\mathrm{Na}^{+}$cation exchange process, resulting in softening of water. More so, in aquifers having clay mineral, $\mathrm{Na}^{+}$derived from the exchangeable sites can exchange with $\mathrm{Ca}^{2+}$ and $\mathrm{Mg}^{2+}$, causing elevated $\mathrm{Na}^{+}$level (Marghade et al. 2010).

Conversely, Scholler index (Si) (Scholler 1965) can be used to evaluate the ion exchange process (Table 9). Water samples from both deep and shallow groundwater in the study area have positive $\mathrm{Si}$, suggesting overall base exchange reactions in the underlying aquifer. In aquifers where alkaline rock minerals are exchanged with $\mathrm{Na}^{+}$ions, $\left(\mathrm{HCO}_{3}>\mathrm{Ca}+\mathrm{Mg}\right)$ indicates base exchange soft water. Hardened water is formed when $\mathrm{Na}^{+}$ions are exchanged with alkaline rocks $\left(\mathrm{Ca}+\mathrm{Mg}>\mathrm{HCO}_{3}\right)$. Similarly, Versluy's index (Versluys 1916), was positive in both shallow and deep groundwater, suggesting overall base exchange reaction in both shallow and deep groundwater (Table 9). Table 10 summarizes the geochemical aspects of groundwater samples (Panaskar et al. 2016). Two faces can be discerned. The alkaline earth $(\mathrm{Ca}+\mathrm{Mg})$ is greater than the alkalis in shallow groundwater, whereas the alkalis $(\mathrm{Na}+\mathrm{K})$ are greater than the alkaline earth in deep groundwater.
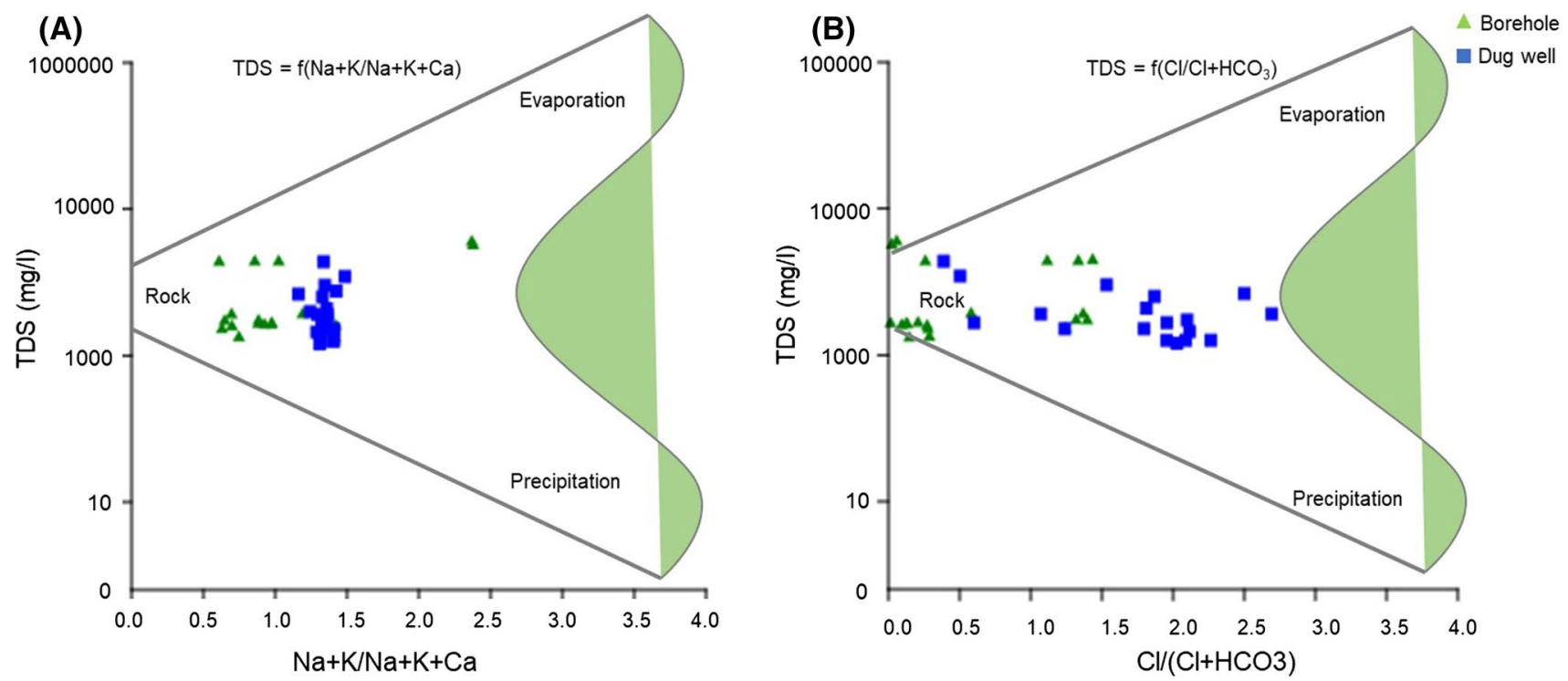

Fig. 9 Gibbs plot showing major natural mechanisms controlling groundwater chemistry 


\section{Hydrogeochemical faces}

The Piper trilinear diagram (Fig. 8) (Piper 1944), shows that samples derived from deep groundwater fall in the class of $\mathrm{Ca}-\mathrm{Mg}-\mathrm{SO}_{4}-\mathrm{HCO}_{3}$, and Mixed $\mathrm{Mg}-\mathrm{Na}-\mathrm{K}-\mathrm{SO}_{4}$ water type, whereas in the shallow aquifer, groundwater falls in $\mathrm{Ca}-\mathrm{Na}-\mathrm{K}-\mathrm{Cl}-\mathrm{HCO}_{3}$ and mixed $\mathrm{HCO}_{3}-\mathrm{Cl}-\mathrm{SO}_{4}$ water type. The hydrogeochemical faces in Sokoto Basin are mainly of two types: $\mathrm{Ca}-\mathrm{Mg}-\mathrm{HCO}_{3}$ and $\mathrm{Ca}-\mathrm{Mg}-\mathrm{SO}_{4}-\mathrm{Cl}$. These faces perhaps are derived from dissolution of $\mathrm{Ca}^{2+}$ and $\mathrm{Mg}^{2+}$ carbonates (Anderson and Ogilbee 1973; Uma 1993; Alagbe 2006). The observed slightly variability in the faces can be related to geology, as most previous reporting of groundwater, faces come from the Cretaceous and Tertiary section of the basin. But new studies comparing groundwater faces between the Basement Complex and Cretaceous and Tertiary sections of the Sokoto Basin are required for further evaluation.

\section{Gibbs model}

The mechanism controlling water chemistry was further evaluated using a plot of weight ratio of TDS versus $[\mathrm{Na}+\mathrm{K}] / \mathrm{Na}+\mathrm{K}+\mathrm{Ca}]$ and $[\mathrm{Cl}] /\left[\mathrm{Cl}+\mathrm{HCO}_{3}\right]$ for cations and anions, respectively (Fig. 9). The model reveals that rock weathering is the dominant mechanism controlling groundwater chemistry in the study area (Gibbs 1970; Rakotondrabe et al. 2018). The observed mechanism is perhaps derived from the Geology and Geography of the study area, which is in the Sokoto Basin (semiarid). The lithology here is mainly comprised of sands and clays of different textural classes overlying a crystalline basement complex (CBC). The lithologic logs from CBC in southern parts of Kebbi State show the lithology is mainly comprised of gneisses, granites, quartzite, and schist (Anderson and Ogilbee 1973; Kogbe 1986; Offodile 2002).

\section{Anthropogenic inputs}

Variations of TDS in groundwater are due to contamination from anthropogenic sources (Marghade et al. 2010). Ions including $\mathrm{Na}^{+}, \mathrm{Cl}^{-}, \mathrm{SO}_{4}{ }^{2-}$, and $\mathrm{NO}_{3}{ }^{-}$are mainly derived from anthropogenic sources-sewage ejections from municipal and industrial sources as well as the application of chemical fertilizer and manure. Correlations between $\mathrm{Na}^{+}, \mathrm{Cl}^{-}$, $\mathrm{SO}_{4}{ }^{2-}$, and $\mathrm{NO}_{3}{ }^{-}$with TDS indicates how anthropogenic activities accelerate changes in groundwater composition (Marghade et al. 2010). TDS correlates positively with $\mathrm{Na}^{+}, \mathrm{Cl}^{-}, \mathrm{Ca}^{2+}, \mathrm{SO}^{2-}$, and $\mathrm{NO}_{3}^{-}$. Negative correlations between TDS and $\mathrm{Na}^{+}$in shallow and deep groundwater informs silicate weathering reaction was not the source of $\mathrm{Na}^{+}$(Tables 7, 8). Municipal and industrial sewage and effluents from mining and engineering works can result in a positive correlation between $\mathrm{Na}^{+}$and TDS (Dragon 2008). Significant correlations between TDS and $\mathrm{Cl}$ and positive correlation between TDS and $\mathrm{SO}_{4}$ in shallow groundwater suggest input from anthropogenic origins. Negative correlations between TDS and $\mathrm{NO}_{3}{ }^{-}$in both shallow and
Table 11 Varimax rotated R-mode factor loadings matrix

\begin{tabular}{|c|c|c|c|c|c|c|}
\hline \multirow[t]{2}{*}{ Parameters } & \multicolumn{3}{|c|}{ Shallow groundwater } & \multicolumn{3}{|c|}{ Deep groundwater } \\
\hline & PC1 & $\mathrm{PC} 2$ & PC3 & $\mathrm{PC} 1$ & $\mathrm{PC} 2$ & PC3 \\
\hline$T\left({ }^{\circ} \mathrm{C}\right)$ & 0.377 & 0.242 & -0.378 & -0.563 & 0.138 & -0.409 \\
\hline $\mathrm{pH}$ & 0.688 & 0.044 & 0.134 & -0.042 & 0.773 & 0.07 \\
\hline TDS & 0.784 & -0.283 & 0.026 & 0.951 & -0.228 & 0.069 \\
\hline $\mathrm{EC}$ & 0.848 & -0.34 & 0.002 & 0.951 & -0.228 & 0.068 \\
\hline $\mathrm{K}^{+}$ & 0.596 & 0.24 & $\mathbf{0 . 5 3 3}$ & -0.308 & -0.558 & 0.649 \\
\hline $\mathrm{Na}^{+}$ & 0.091 & 0.955 & -0.12 & -0.175 & 0.291 & 0.479 \\
\hline $\mathrm{Ca}^{2+}$ & 0.832 & -0.336 & 0.007 & 0.066 & -0.543 & -0.154 \\
\hline $\mathrm{Cu}^{2+}$ & 0.122 & 0.267 & -0.719 & -0.113 & -0.043 & 0.765 \\
\hline $\mathrm{Fe}^{3+}$ & -0.176 & 0.214 & -0.815 & -0.161 & -0.011 & -0.482 \\
\hline $\mathrm{Zn}^{2+}$ & -0.34 & 0.179 & 0.560 & 0.418 & -0.73 & 0.069 \\
\hline $\mathrm{Mg}^{2+}$ & 0.332 & 0.248 & 0.694 & 0.879 & -0.033 & -0.239 \\
\hline $\mathrm{PO}_{4}^{3-}$ & 0.28 & 0.057 & -0.023 & -0.362 & -0.269 & -0.394 \\
\hline $\mathrm{Cl}^{-}$ & 0.766 & 0.37 & 0.212 & -0.028 & 0.198 & 0.385 \\
\hline $\mathrm{HCO}_{3}^{-}$ & 0.036 & -0.948 & -0.04 & -0.185 & 0.588 & 0.253 \\
\hline $\mathrm{SO}_{4}^{2-}$ & 0.272 & -0.154 & 0.335 & -0.508 & 0.590 & 0.065 \\
\hline $\mathrm{NO}_{3}^{-}$ & -0.133 & 0.520 & -0.108 & 0.197 & 0.193 & 0.556 \\
\hline Eigenvalues & 4.351 & 2.773 & 2.256 & 4.327 & 2.512 & 1.957 \\
\hline$\%$ of variance & 27.195 & 17.333 & 14.098 & 27.045 & 15.698 & 12.232 \\
\hline Cumulative\% & 27.195 & 44.529 & 58.627 & 27.045 & 42.742 & 54.975 \\
\hline
\end{tabular}


(A)

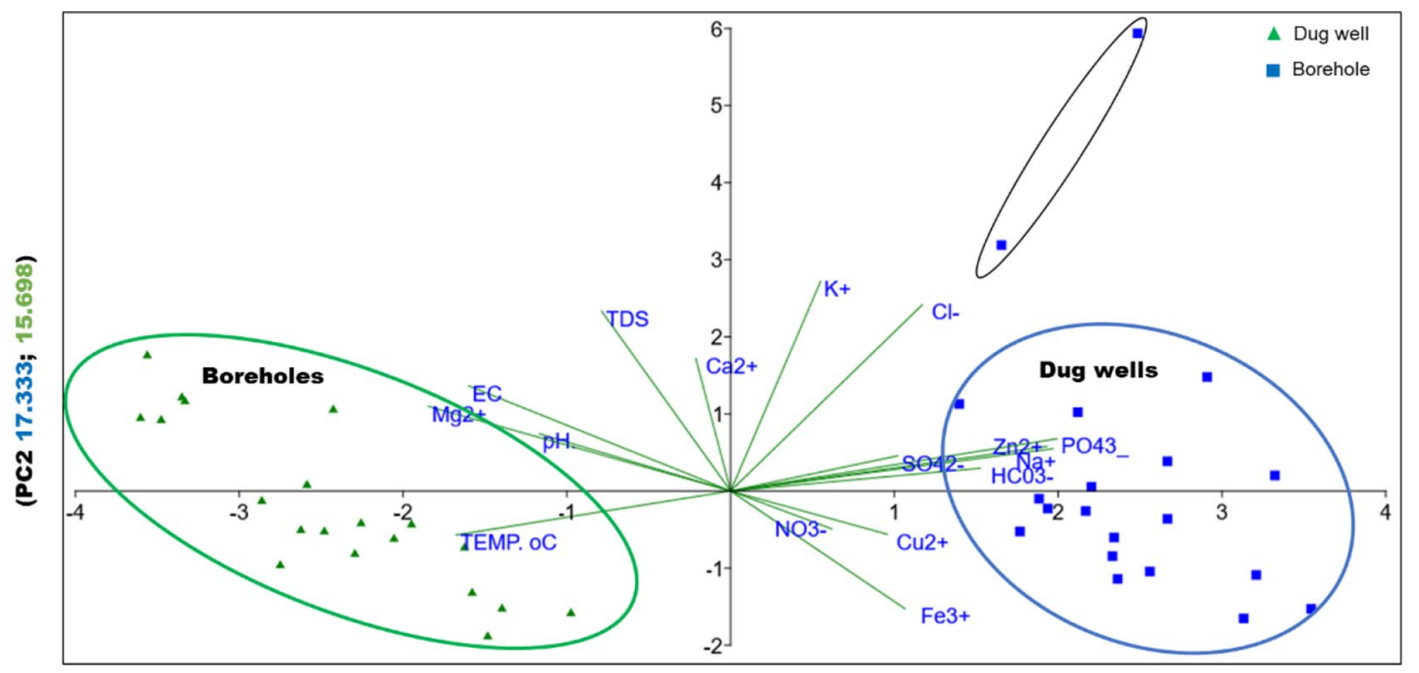

(PC1 27.195; 27.045)

(B)

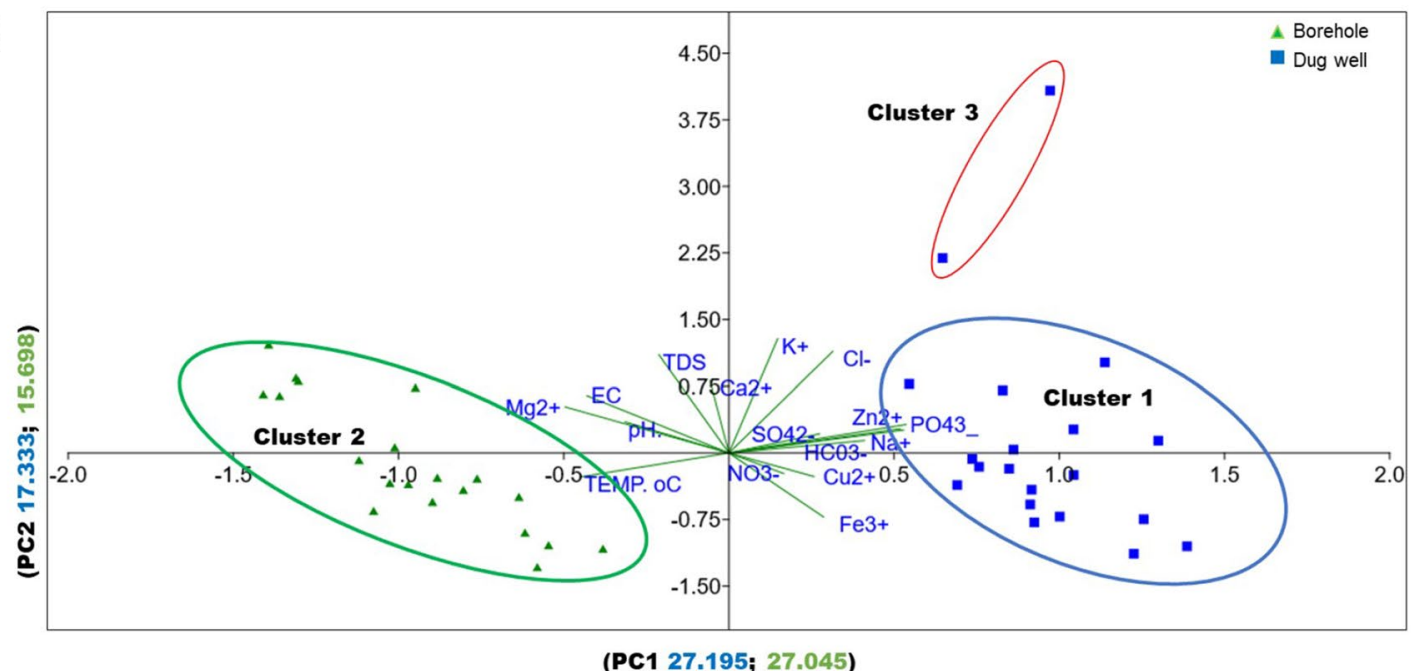

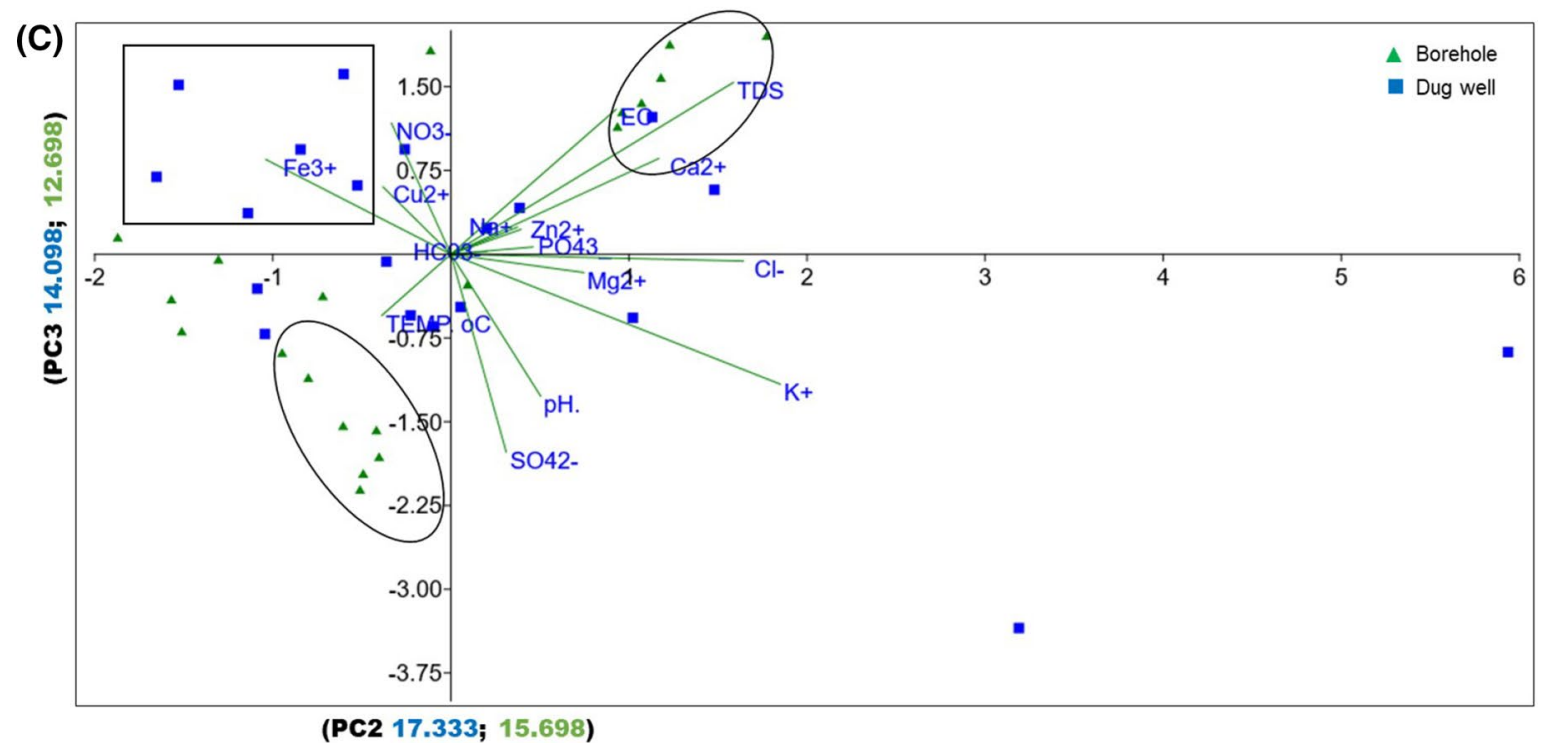

(PC2 17.333; 15.698) 
4Fig. 10 a PCA biplots for examining relationships between groundwater quality parameters from 40 groundwater sources. b Biplot of PC1 versus PC2 of hydrochemical data matrix ( $y$-mean centered) for 17 parameters analyzed from 40 groundwater samples. c Biplot of PC2 versus PC3 of hydrochemical data matrix for seventeen parameters analyzed from 40 groundwater samples

deep groundwater (Tables 7, 8) suggest that groundwater in the study area is less influenced by anthropogenic activities.

However, the topographical setting of the study area may reduce the anthropogenic impact, since effluents may be washed off by a single storm. So, impurities may be transported downhill to the nearby river floodplains and transported downstream. Since Basement Complex aquifers are primarily recharged along cracks and other openings, the chances of getting contaminants may be low if the recharge zones are located away from the source of pollutants. This perhaps explains the low anthropogenic inputs in the study area. Yet new studies are required for further evaluation. Positive correlations between TDS and $\mathrm{SO}_{4}{ }^{2-}$ also indicates contamination from the anthropogenic origin in the absence of geological inputs and this cannot be totally ruled out in the study area, owing to its geology. $\mathrm{SO}_{4}{ }^{2-}$ and $\mathrm{NO}_{3}{ }^{-}$correlate negatively $(r=-0.29 ; r=-0.06)$ in shallow and deep groundwater suggesting the different origin of the two ions, perhaps derived from both the rock mineral and anthropogenic activities (Dragon 2008). Weak correlations between $\mathrm{Cl}^{-}$and $\mathrm{NO}_{3}^{-}(r=0.07 ; r=0.41)$ in both the shallow and deep groundwater suggest that the two ions might have originated from a different source. Negative correlations between $\mathrm{Ca}^{2+}$ and $\mathrm{NO}_{3}{ }^{-}(r=-0.23 ; r=0.04), \mathrm{NO}_{3}{ }^{-}$and $\mathrm{SO}_{4}{ }^{2-}(r=-029 ; r=-0.06)$ and weak positive correlation between $\mathrm{Cl}^{-}$and $\mathrm{NO}_{3}{ }^{-}(r=0.07 ; r=0.41)$ in both shallow and deep aquifers made it very difficult to relate these ions to anthropogenic inputs.

\section{Principal component analysis}

In this paper, PCA was carried out using two sets of groundwater quality data, comprising of 20 groundwater samples each from shallow and deep groundwater sources, to identify and describe the factors that affect groundwater chemistry of the two groundwater environments. PCA was performed on a subset of 17 selected water quality variables, namely: Temperature, EC, pH, TDS, TH, $\mathrm{K}^{+}, \mathrm{Na}^{+}, \mathrm{Ca}^{2+}, \mathrm{Cu}^{2+}, \mathrm{Fe}^{3+}$, $\mathrm{Zn}^{2+}, \mathrm{Mg}^{2+}, \mathrm{Cl}^{-}, \mathrm{HCO}_{3}{ }^{-}, \mathrm{PO}_{4}{ }^{3-}, \mathrm{NO}_{3}{ }^{-}$, and $\mathrm{SO}_{4}{ }^{2-}$, which characterized the overall groundwater chemistry outline. The PCA results comprising the loadings, eigenvalues, and percentages of total variance are summarised in Table 11. The extraction of three factors each from shallow and deep groundwater was built on the proportion of variance accrued, which included a percentage greater than $80 \%$ (Lin et al. 2012; Selvakumar et al. 2017). The computed data indicate these three factors explained $58.63 \%$ and $54.98 \%$ of the total variance within the data matrix in shallow and deep groundwater, respectively. Based on 'scree test,' the three factors with typical factor loadings suggest three different noticeable contributions were involved in controlling the composition of shallow and deep groundwater in the study area. Factor 1 explained $27.195 \%$ and $27.045 \%$ of the variability of groundwater data in shallow and deep groundwater, respectively. In shallow groundwater, Factor 1 has corresponded to high positive loadings on $\mathrm{pH}$, TDS, $\mathrm{EC}, \mathrm{K}^{+}, \mathrm{Ca}^{2+}$, and $\mathrm{Cl}^{-}$as well as TDS, EC, and $\mathrm{Mg}^{2+}$ in deep groundwater. Factor 1 can be related to rock weathering since all the parameters having high positive loading on these factors have a geologic origin.

Potassium, for instance, is derived from many minerals through the weathering process. Such minerals include microcline and orthoclase feldspars, chlorine minerals, sylvite, carnalite, and clay minerals. Calcium in groundwater is primarily derived from rock minerals such as apatite, calcite, dolomite, fluorite, gypsum, limestone, and marble. In most natural aquifers, $\mathrm{Cl}^{-}$occurs as a key ion, yet $\mathrm{Cl}^{-}$is continuously added in freshwaters by anthropogenic activities in many receiving glasses of water (Gregory et al. 2015). Factor 2 explained $17.33 \%$ and $14.09 \%$ of the variability in shallow and deep groundwater, respectively. The factor corresponded to high positive loadings on $\mathrm{Na}^{+}$and $\mathrm{NO}_{3}{ }^{-}$in shallow groundwater, $\mathrm{pH}, \mathrm{HCO}_{3}{ }^{-}$and $\mathrm{SO}_{4}{ }^{2-}$ in deep groundwater. A large part of $\mathrm{Na}^{+}$comes from rocks and soil, whereas, $\mathrm{NO}_{3}{ }^{-}$is derived in aquifers from agriculture via runoff and oxidation of ammonia. Bicarbonate comes from carbonates dissolution and like nitrate, and $\mathrm{SO}_{4}{ }^{2-}$ can be derived from both geogenic and anthropogenic sources. Therefore, Factor 2 can be related to both geogenic and anthropogenic influence. High positive loadings on $\mathrm{HCO}_{3}{ }^{-}$in deep groundwater inferred that it is expected to control the character of other parameters (Lin et al. 2012). Factor 3 corresponded to high positive loadings on $\mathrm{K}^{+}$and $\mathrm{Zn}^{2+}$ in shallow groundwater, $\mathrm{K}^{+}, \mathrm{Na}^{+}$, and $\mathrm{NO}_{3}{ }^{-}$in deep groundwater water. Factor 3 can be related to rock weathering in shallow groundwater since both $\mathrm{Na}^{+}$and $\mathrm{Zn}^{2+}$ are derive from rock weathering and soil. In deep groundwater, this factor can be related to both geologic and anthropogenic influence. However, negative loading on $\mathrm{pH}$ in $\mathrm{PC} 1$ in the deep aquifer was deemed reasonable since $\mathrm{pH}$ attained a converse relationship with rocks of carbonate origin (Lin et al. 2012).

Despite the variability in water table depths, groundwater composition in the study area is controlled by rock weathering. Using scatter plot, water quality parameters cluster nicely along the spectrum of shallow and deep groundwater, respectively, in a biplot of PC1 and PC2 (Fig. 10a, b). The two components joint together explained 58.626\% (shallow groundwater) and $54.975 \%$ (deep groundwater) of the variability within the data set. Interestingly the results are 


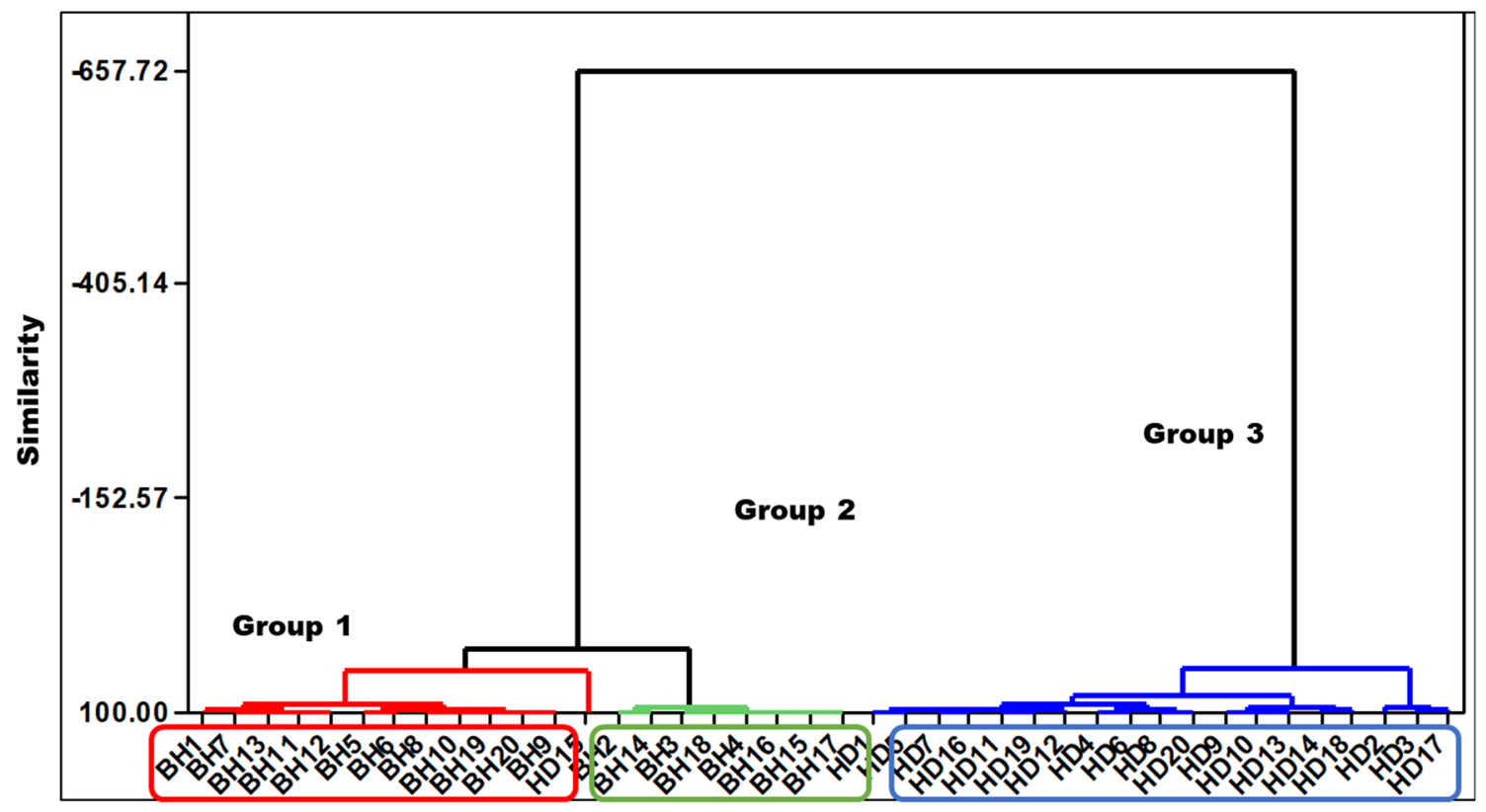

Groundwater sources

Fig. 11 Dendrogram produced from cluster analysis based on sampling boreholes to understand the most important hydrochemical physiognomies in Basement Complex areas of southern Kebbi State. Three groups were distinguished viz. Group 1 (BH1, BH7, BH11, BH12, BH5, BH6, BH8, BH10, BH19, BH20, BH9 and HD15),

remarkable as the parameters form a comparatively tight cluster around the water sources. All the 17 originally analyzed variables (or parameters) are clearly visible on the biplot, even though these elements are selected on the basis of their absolute size (i.e., high elemental absorptions) which was established by reference to the raw data matrix. As a result, the significance or otherwise of these parameters is identified from this plot (Kokot et al. 1994, 1998; Kokot and Stewart 1995; Olsen et al. 2012; Zhang et al. 2015). Although a good clustering is observed in the biplot of PC1 and PC2, the biplot of PC2 and PC3 (Fig. 10c) indicates wide dispersity of groundwater quality parameters, making it difficult to identify any pattern. It is not clear which of these later components is important.
Group 2 (BH2, BH14, BH3, BH18, BH4, BH16, BH15, BH17and HD1) and Group 3 (HD5, HD7, HD16, HD11, HD19, HD12, HD4, HD66, HD8, HD20, HD9, HD10, HD13, HD14, HD18, HD2, HD3 and HD17)

\section{Hierarchical cluster analysis}

The vital role of HCA is to discrete the parameters in a raw data matrix into separate classes designated by the user without any prior hypotheses. The HCA is an unverified classification technique that reveals inherent assembly or recognizing the pattern of a dataset without a prior hypothesis with regards to the data so that the objects of the system can be classified into clusters based on their resemblances (Lin et al. 2012; Machiwal and Jha 2015). In this study, Ward's algorithmic clustering technique subsequent to the Euclidean distance was used. This is considered as the most powerful grouping tool (Dou et al. 2008; Shyu et al. 2011; Lin et al. 2012), because it is capable of minimizing the misrepresenting effect or sum of squared distances of centroids from two theoretical groups produced at each step (Lin et al.
Table 12 Summary of chemical indices used in determining groundwater suitability for irrigation

\begin{tabular}{lll}
\hline Parameter & Formula for Calculation & Source \\
\hline Kelly index $(\mathrm{Ki})$ & $\mathrm{Na} /(\mathrm{Ca}+\mathrm{Mg})$ & Kelly (1940) \\
Magnesium hazard $(\mathrm{MH})$ & $\mathrm{Mg} \times 100 /(\mathrm{Ca}+\mathrm{Mg})$ & Szablocs and Darab (1964) \\
Permeability index $(\mathrm{Pi})$ & $\mathrm{Na}+\sqrt{\mathrm{HCO}_{3}} /(\mathrm{Ca}+\mathrm{Mg}+\mathrm{Na} \times 100)$ & Doneen (1962) \\
Sodium adsorption ratio (SAR) & $\mathrm{Na}^{+} / \sqrt{\mathrm{Ca}}+\mathrm{Mg} / 2$ & Ayers and Westcot (1976) \\
Sodium percent (SP) & $\mathrm{Na}^{+} \times 100 /(\mathrm{Ca}+\mathrm{Mg}+\mathrm{Na}+\mathrm{K})$ & Wilcox (1955) \\
Versluys index $(\mathrm{Vi})$ & $\mathrm{Na} /(\mathrm{Na}+\mathrm{Ca}+\mathrm{Mg})$ & Versluys (1916) \\
\hline
\end{tabular}


Table 13 Summary of chemical indices of shallow and deep groundwater in the study area

\begin{tabular}{|c|c|c|c|c|c|c|c|c|c|c|c|}
\hline \multirow[t]{2}{*}{ Source type } & \multicolumn{5}{|c|}{ Shallow groundwater } & \multirow[t]{2}{*}{ Source type } & \multicolumn{5}{|c|}{ Deep groundwater } \\
\hline & $\overline{\mathrm{Ki}}$ & SAR & SP & MH & PI & & $\overline{\mathrm{Ki}}$ & SAR & SP & MH & PI \\
\hline DGW1 & 0.1 & 0.5 & 4.1 & 60.8 & 14.6 & SGW1 & 23.0 & 97.6 & 87.9 & 27.8 & 2024.4 \\
\hline DGW2 & 0. & 0.8 & 5.6 & 23.6 & 30.6 & SGW2 & 11.8 & 71.8 & 85.2 & 13.5 & 2148.6 \\
\hline DGW3 & 0.0 & 0.0 & 0.1 & 33.2 & 2.6 & SGW3 & 9.2 & 74.2 & 80.7 & 21.5 & 2575.7 \\
\hline DGW4 & 0.0 & 0.0 & 0.1 & 90.8 & 3.1 & SGW4 & 16.3 & 84.5 & 86.9 & 29.6 & 2144.2 \\
\hline DGW5 & 0.0 & 0.2 & 1.6 & 48.0 & 5.1 & SGW5 & 21.0 & 100.7 & 88.6 & 13.0 & 87.9 \\
\hline DGW6 & 0.3 & 1.4 & 9.6 & 36.0 & 30.5 & SGW6 & 16.7 & 96.1 & 88.5 & 9.1 & 1963.6 \\
\hline DGW7 & 0.1 & 0.6 & 4.4 & 85.3 & 14.8 & SGW7 & 11.5 & 72.7 & 79.6 & 50.0 & 1909.4 \\
\hline GW8 & 0.2 & 0.7 & 4.7 & 79.7 & 15.0 & SGW8 & 32.5 & 133.9 & 90.8 & 29.4 & 2064.4 \\
\hline DGW9 & 0.0 & 0.2 & 1.3 & 58.1 & 6.2 & SGW9 & 21.9 & 100.4 & 88.5 & 4.8 & 2033.2 \\
\hline DGW10 & 0 & 1.9 & 12.9 & 72.7 & 67.9 & SGW10 & 55.2 & 174.6 & 91.8 & 30.0 & 2848.6 \\
\hline DGW11 & 0.2 & 1.3 & 9.4 & 59.6 & 31.3 & SGW11 & 13.2 & 76.1 & 85.9 & 54.5 & 1809.6 \\
\hline DGW12 & 0.0 & 0.2 & 1.3 & 55.1 & 5.0 & SGW12 & 24.2 & 105.5 & 88.8 & 73.7 & 1901.8 \\
\hline DGW13 & 0.3 & 1.4 & 10.0 & 74.9 & 71.5 & SGW13 & 61.3 & 184.0 & 92.0 & 22.2 & 2602.9 \\
\hline DGW14 & 0.0 & 0.2 & 1.5 & 13.0 & 14.4 & SGW14 & 23.0 & 105.4 & 89.0 & 28.6 & 1911.9 \\
\hline DGW15 & 0.1 & 0.6 & 4.7 & 60.3 & 31.0 & SGW15 & 0.0 & 0.3 & 2.4 & 7.0 & 2163.5 \\
\hline DGW16 & 0.0 & 0.0 & 0.0 & 60.4 & 19.7 & SGW16 & 34.5 & 119.5 & 89.0 & 33.3 & 2630.8 \\
\hline DGW17 & 0.3 & 1.8 & 12.2 & 85.6 & 46.6 & SGW17 & 8.9 & 62.4 & 83.2 & 14.3 & 2249.2 \\
\hline DGW18 & 0.0 & 0.4 & 2.7 & 35.2 & 17.3 & SGW18 & 11.1 & 62.0 & 83.1 & 9.7 & 2415.2 \\
\hline DGW19 & 0.2 & 0.8 & 5.8 & 85.0 & 86.2 & SGW19 & 36.4 & 126.2 & 89.5 & 33.3 & 2031.9 \\
\hline DGW20 & 0.2 & 1.3 & 9.8 & 62.5 & 52.5 & SGW20 & 92.9 & 211.8 & 91.6 & 76.9 & 2528.7 \\
\hline
\end{tabular}

$K i$ Kelly's index, $S A R$ sodium adsorption ratio, $M H$ magnesium hazard
2012). Using HCA, groundwater sources with comparable hydrochemical physiognomies can be grouped into the same cluster. The graphics collection of the clustering processes in this study is offered as a dendrogram. Base on the dendrogram (Fig. 11), three groups of groundwater sources can be distinguished.

Group 1 (BH1, BH7, BH11, BH12, BH5, BH6, BH8, BH10, BH19, BH20, BH9 and HD15), Group 2 (BH2, BH14, BH3, BH18, BH4, BH16, BH15, BH17and HD1) and Group 3 (HD5, HD7, HD16, HD11, HD19, HD12, HD4, HD66, HD8, HD20, HD9, HD10, HD13, HD14, HD18, HD2, HD3 and HD17).Generally, the lithology of these boreholes is comprised of clay, ironstone, schists, and sands of different textural groups. Group 1 is characterized by a higher temperature, magnesium, $\mathrm{pH}$, TDS, EC, and calcium. Group 2 corresponded to groundwater sources having higher potassium, chloride, sodium, sulfate, phosphate, zinc and bicarbonate. Group 3 is comprised of water sources having higher concentrations of copper, iron, and nitrate. Group 1 can be related to natural geogenic processes as it is comprised of ions derived primarily from rock minerals (notably $\mathrm{Ca}^{2+}$ ). Similarly, Group 2 can be related to natural geogenic processes. Lastly, Group 3 can be related to both anthropogenic (notably $\mathrm{NO}_{3}{ }^{-}$pollution) and rock weathering.

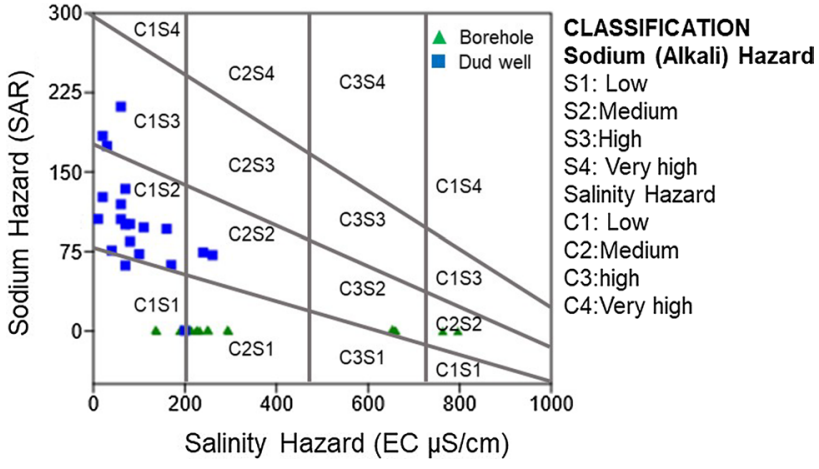

Fig. 12 USSL classification of groundwater samples from shallow and deep aquifers

\section{Suitability for irrigation use}

The suitability of groundwater for irrigation can be evaluated using a total concentration of soluble salts (SAR) which is express in terms of specific conductance (Sadashivaiah et al. 2008; Rakotondrabe et al. 2018). Sodium percent was calculated following Kumar et al. (2014) and Rakotondrabe et al. (2018). Soil often reacts with sodium to decrease soil permeability, which results in high sodium concentration. This causes cation exchange between $\mathrm{Mg}^{2+}$ and $\mathrm{Ca}^{2+}$ in soil under wet conditions. Water and air circulations are reduced as a consequent to this process. In the same vein, Kelly's 


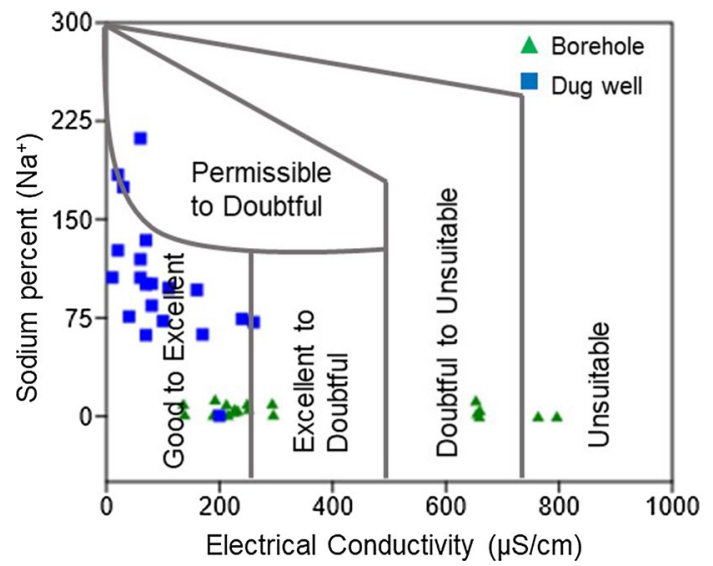

Fig. 13 Wilcox diagram showing groundwater classification for irrigation use

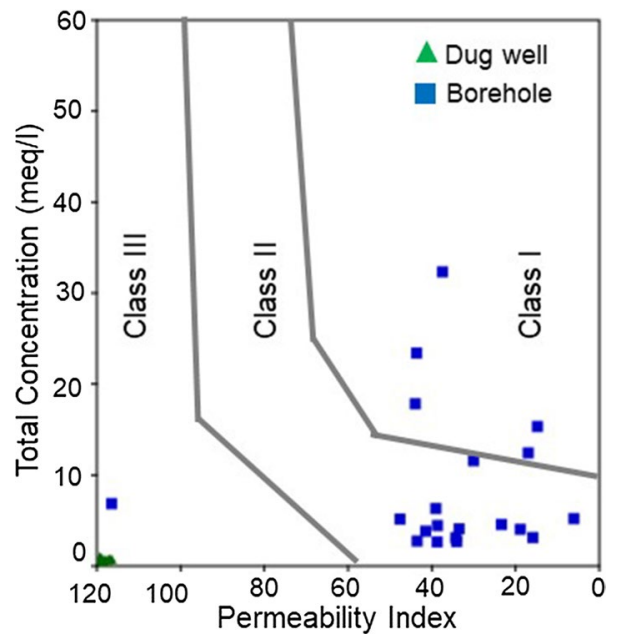

Fig. 14 Doneen's chart showing groundwater classification of irrigation water based on PI

index and magnesium adsorption ratio (MAR) were also calculated. Kelly's index value greater than 1 designates water of excellent quality for irrigation use. However, index value less than 1 designates water which is unsuitable for irrigation, because of alkali hazard to crops (Kelly 1940). In calculating Kelley's index, $\mathrm{Ca}^{2+}$ and $\mathrm{Mg}^{2+}$ are measured against $\mathrm{Na}^{+}$. Elevated levels of $\mathrm{Mg}^{2+}$ in ground water disturb the soil quality by changing it to alkali, which subsequently decreases crop yield (Kumar et al. 2014). Also, values of MAR less than 50 in irrigation water are considered appropriate for irrigation use. Often in groundwater, $\mathrm{Ca}^{2+}$ and $\mathrm{Mg}^{2+}$ are found in a state of equilibrium. Elevated $\mathrm{Mg}^{2+}$ in groundwater at levels greater than $\mathrm{Ca}^{2+}$ fast-tracks the degree of $\mathrm{Mg}^{2+}$ saturation, which destroys soil structure, and consequently, reduces its productivity (Goswamee et al. 2015).

The chemical composition of groundwater for irrigation farming affects the soil quality and crop yield (Table 12). The suitability of groundwater for irrigation use hinges on the composition and concentration levels of ions in groundwater (Panaskar et al. 2016). To assess this, the properties of groundwater play an important role including (1) comparative amount of sodium to other cations, (2) total absorption of soluble salts, (3) the bicarbonate absorption in relation to the absorption of $\mathrm{Ca}+\mathrm{Mg}$ (USSL 1954; Panaskar et al. 2016). Using this, an assessment of groundwater appropriateness for irrigation uses has been carried out in the study area using numerous salinity indices viz. sodium adsorption ratio (SAR), sodium percentage (Na\%), Kelly's ratio, magnesium ratio, residual sodium carbonate (RSC), and USSL diagram among others (Panaskar et al. 2016). Table 13 presents the calculated indices from the shallow and deep groundwater in the study area.

\section{Sodium adsorption ratio (SAR)}

The foremost index applied for evaluation of groundwater suitability for agricultural purposes in relation to $\mathrm{Na}^{+}$ absorption which affect soil structure and permeability is SAR (Marghade et al. 2010; Panaskar et al. 2016). SAR is used to measure sodium and/or alkali hazards to crops (Table 13). It provides a clue relating to the magnitude of sodium adsorption by soil. Calcium and $\mathrm{Mg}^{2+}$ in the soil can be displaced as a result of the prolonged application of high Na-rich water. This causes damage to the soil structure and reduced crop yields (Marghade et al. 2010; Panaskar et al. 2016). SAR in deep groundwater ranged from $<0.001$ to 1.9 with a mean value of 0.7 , whereas, in shallow groundwater, it varies between 0.3 and 211.8 with an average value of 103.26. Figure 12 shows the variability in SAR levels between shallow and deep groundwater in the study area.

Groundwater samples having SAR value within the range of 10 and 18 are classified as a good category; however, most of the groundwater samples derived from deep aquifer have SAR value $>18$, with one groundwater sample $($ SAR $<18)$, classified as good.

\section{Sodium percent $(\mathrm{Na} \%)$}

Another index employed to identify the concentration of soluble sodium level in irrigation water is sodium percent $(\mathrm{Na} \%)$. It is applied to reveal sodium hazard to crops (Panaskar et al. 2016). Calcium is replaced by sodium by 


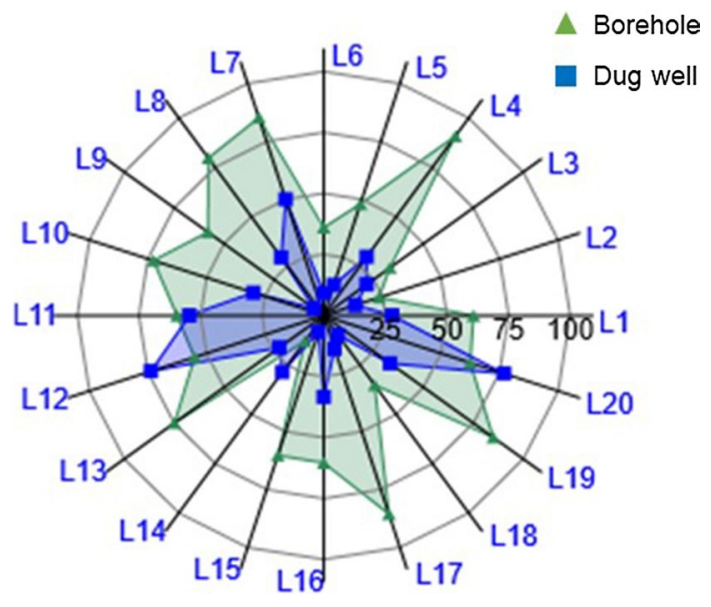

Fig. 15 Radar chart showing the variability of magnesium adsorption ratio between shallow and deep groundwater

process of base exchange which destroys soil structure and consequently reduces soil permeability (Table 12). Using Wilcox plot (Fig. 13), groundwater samples showed marked variability with shallow groundwater samples falling in good to excellent class. Whereas deep groundwater samples vary between good to excellent class and unsuitable to doubtful class, two samples from deep groundwater fall in unsuitable class. Generally, samples from shallow groundwater have very low to high sodium class. However, irrigation water of very low SAR and low salinity $(<200 \mu \mathrm{S} / \mathrm{m})$ affects the rates of water infiltration into soils (Graham et al. 2006).

\section{Permeability index (PI)}

Prolonged application of irrigation water can interfere with soil permeability which is affected by bicarbonate, calcium, magnesium, and sodium (Li et al. 2016; Panaskar et al. 2016). Doneen (1962) developed a standard for evaluating irrigation water suitability using permeability index which is defined as contained (Fig. 14).

Values are express in meq/l. Shallow groundwater classification showed that PI values ranged from 2.6 to 86.2 with a mean value 29.8. In deep groundwater, PI values vary between 0 and 1.9 with an average value of 0.74 . Based on permeability index, three classes can be discerned: Class I is classified as excellent for irrigation; Class II is classified as acceptable; Class III is categorized as unsuitable ( $\mathrm{Li}$ et al. 2016). All the shallow groundwater samples fall in Class III. This is deemed reasonable since the prolonged application of irrigation water of very low salinity is related to poor permeability (Graham et al. 2006). In deep groundwater, 1 sample falls in Class III, 14 samples fall in Class II, and 5 samples fall in Class I. Water samples from deep aquifer can be used for irrigation with little permeability problem, but such water of high SAR level destroys soil structure (Li et al. 2016; Panaskar et al. 2016).

\section{Kelly's index (KI)}

Kelly's index is employed to measure the concentration of $\mathrm{Na}^{+}$against $\mathrm{Ca}^{2+}$ and $\mathrm{Mg}^{2+}$ (Table 13). It is vital to evaluate groundwater suitability for agricultural use. Elevated $\mathrm{Na}^{+}$ level in aquifers produces an objectionable impact on changing characteristics of soil and its permeability; thus, extreme $\mathrm{Na}^{+}$is used as an indicator of alkali hazard (Wagh et al. 2016). Kelly's index is greater than 1 in deep groundwater, whereas, in shallow groundwater, indices are less than 1 (Table 13). Values less than 1 are considered suitable for irrigation, whereas KI values are greater than 1 in irrigation water can be classified as unsuitable for irrigation use (Wagh et al. 2016). KI values in shallow groundwater ranged from 0 to 0.4 with a mean value of 0.13 . KI values are extremely high in shallow groundwater and vary between 0 and 92.9 with an average value of 28.06. The possible reasons for higher KI values in shallow groundwater need to be unveiled as it presents a serious environmental problem.

\section{Magnesium adsorption ratio (MAR)}

Magnesium hazard is also used to characterize groundwater and assess its suitability for irrigation use by revealing the amount of $\mathrm{Mg}^{2+}$ over $\mathrm{Ca}^{2+}$ (Ragunath 1987; Wagh et al. 2016). The MAR ratio as calculated in Table 13 shows that MAR values ranged from 13.0 to 90.8 with a mean value of 58.3 in shallow groundwater. In deep groundwater, MAR values vary between 4.8 and 76.9 with an average value of 30.17. Based on mean MAR, shallow groundwater in the study area is unfit for irrigation use. Usually, magnesium and calcium occur in a state of equilibrium in groundwater sources. The concentration of magnesium beyond calcium in irrigation water fast-tracks the magnitude of $\mathrm{Mg}^{2+}$ saturation and consequently damages soil structure and reduces crop yields. High magnesium in irrigation water impacts soil quality by converting it to alkali which eventually reduces its productivity. The variability of MAR in the study area is further illustrated using a radar chart (Fig. 15). Overall, groundwater evaluation shows deep aquifers in the study area hold water of good quality as compared to shallow groundwater sources.

\section{Implications for groundwater quality in Sub-Saharan Africa}

Characterization of groundwater in the study area showed marked variability between aquifers. Groundwater

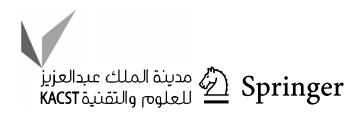




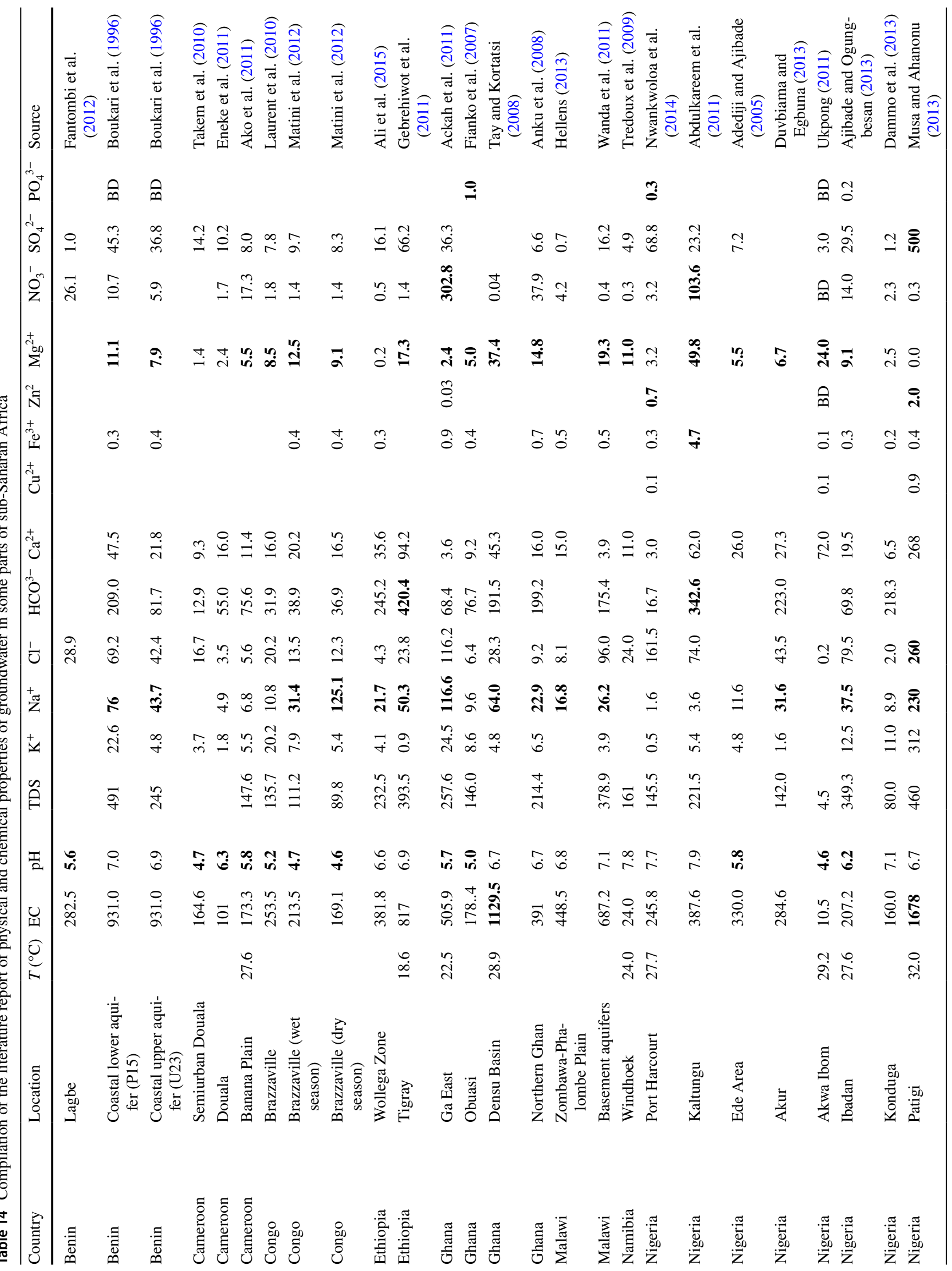




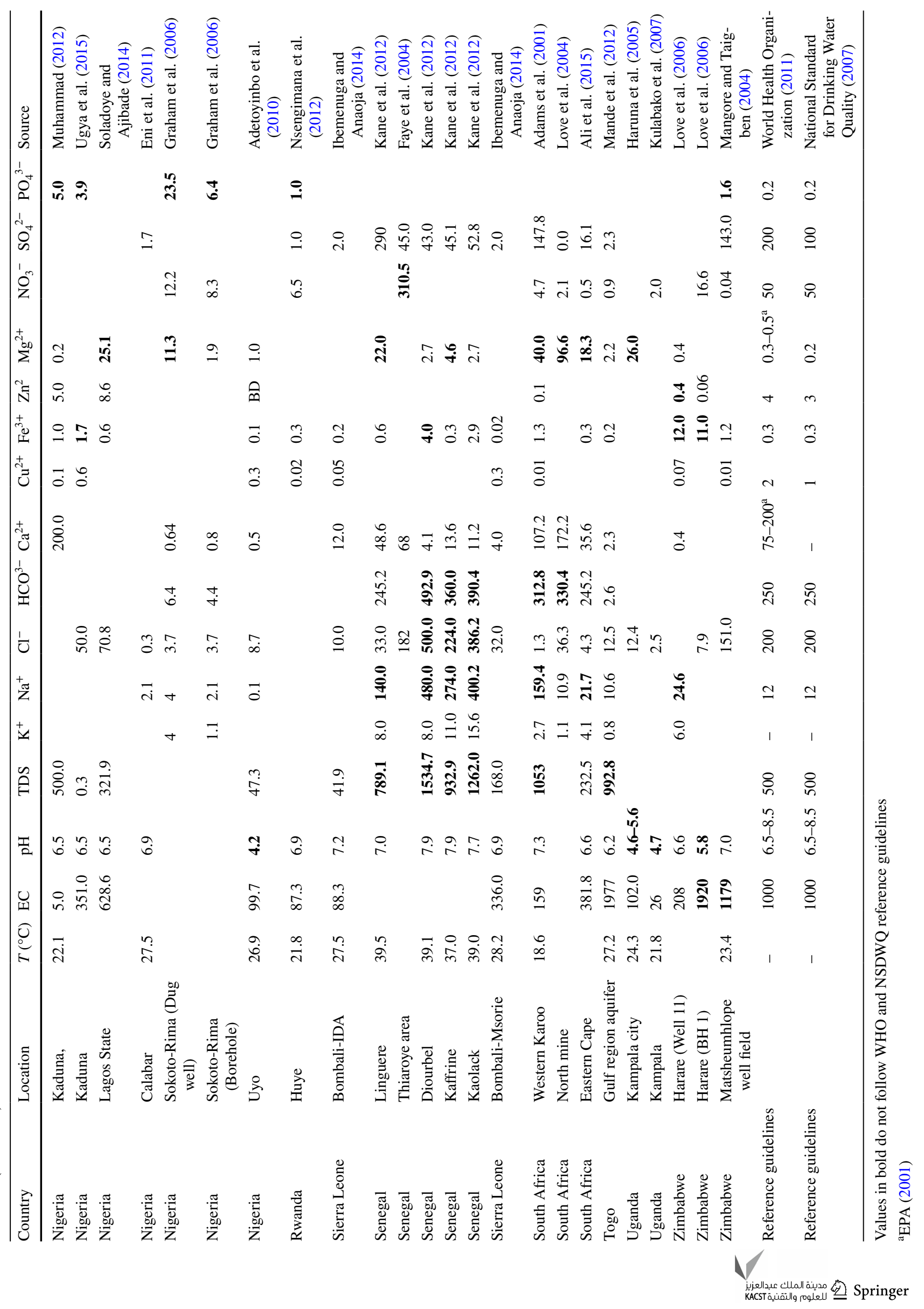




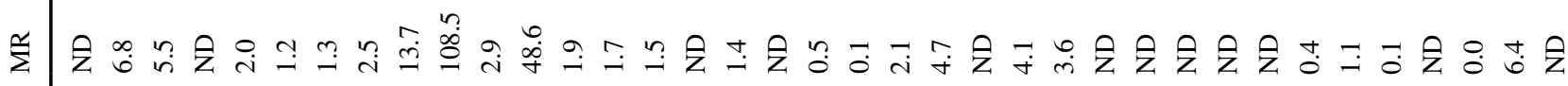

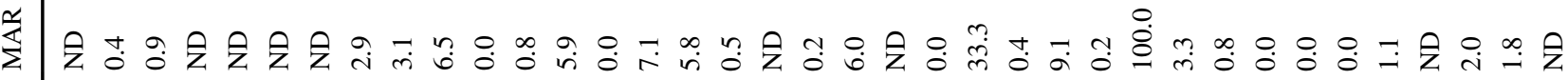

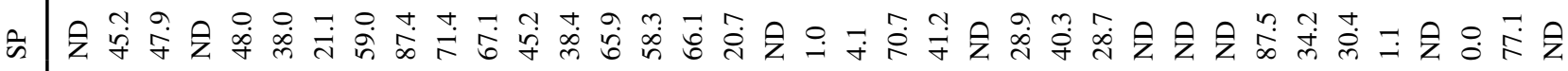

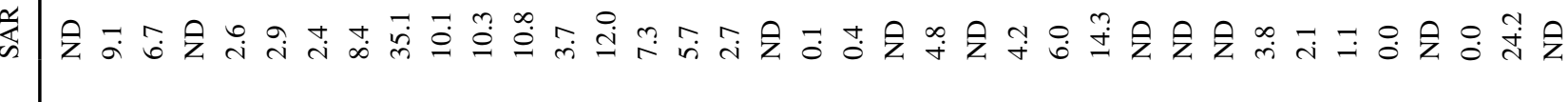

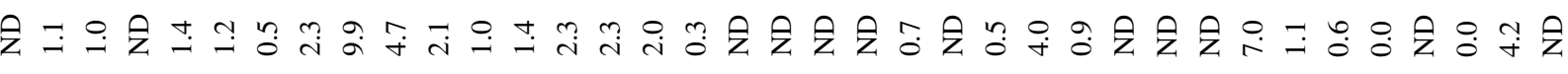
) ヨ 곡 合

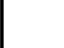

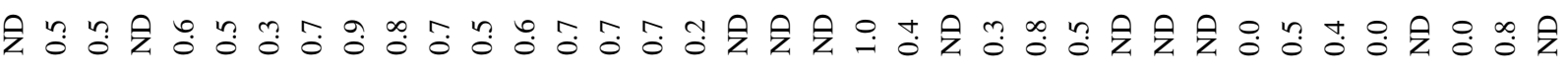
(1) 


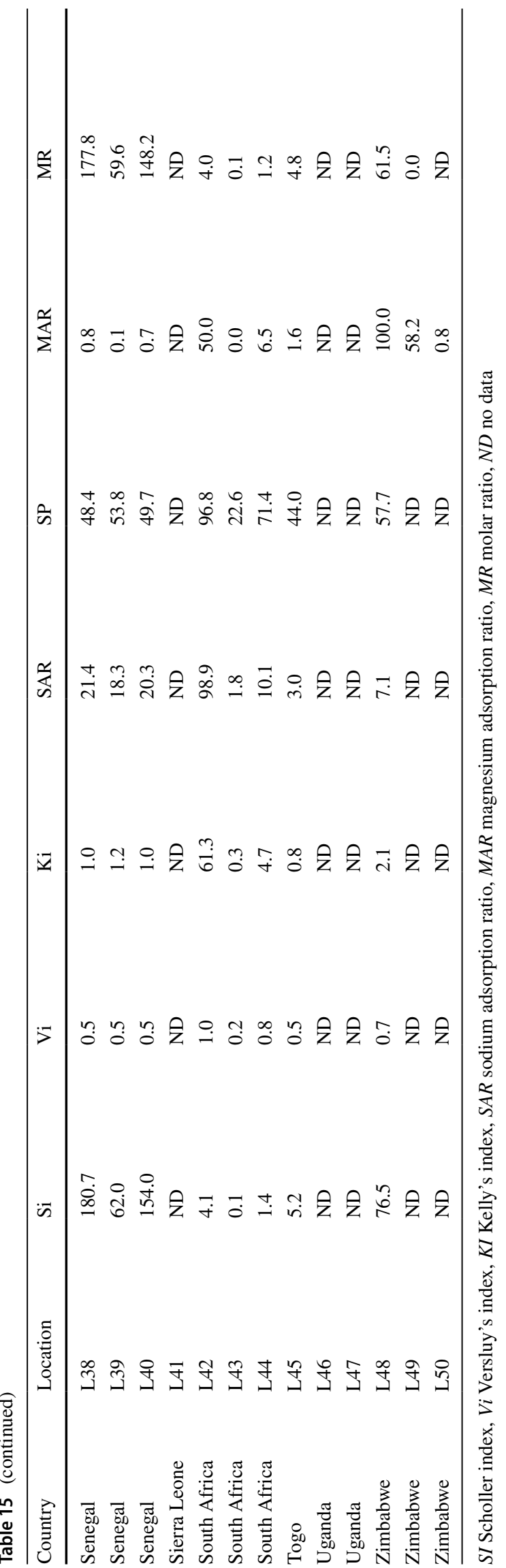

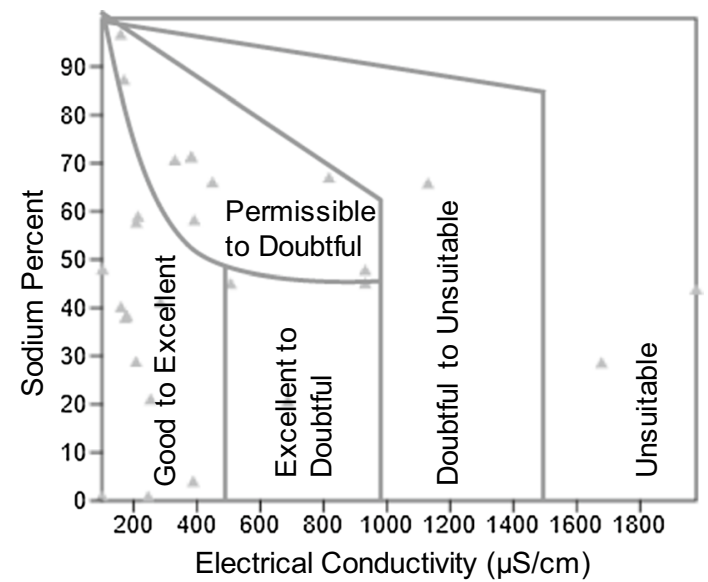

Fig. 16 Wilcox plot showing irrigation water classification in subSaharan Africa

parameters showed marked variability between the shallow and deep groundwater. To better understand the composition of groundwater in the rest of SSA, data from 50 locations from the literature was compiled (Table 14). Further Table 14 shows that evaluation of groundwater quality in SSA is constrained by lack of data. Results from the patchy data derived from the literature indicate that $16.7 \%(n=24)$ of groundwater in SSA have temperatures above $30{ }^{\circ} \mathrm{C}$, $90.0 \%(n=40)$ have EC values above WHO reference guidelines $(1000 \mu \mathrm{S} / \mathrm{cm})$. At least, $38.6 \%(n=44)$ of groundwater sources in SSA are acidic to alkaline in nature. Scholler and Versluy's indices are positive, indicating overall base exchange reactions in aquifers underlying SSA. Kelly's index is greater than 1 in about 10 locations, indicating water which is unsuitable for irrigation use.

Sodium percent is greater than 20 in most locations in SSA (Table 15). The high rates of sodium indicate the absence of ion exchange reaction between $\mathrm{Ca}^{2+}$ and $\mathrm{Na}^{2+}$. Wilcox plot indicates that most of the groundwater sources in SSA are suitable for irrigation use (Fig. 16). However, some parts of $\mathrm{Na}^{+}$in groundwater aquifers across SSA were not derived from silicate weathering, because the molar ratio is greater than 1 in most locations. Therefore, groundwater in SSA is not deficient in $\mathrm{Mg}^{2+}+\mathrm{Ca}^{2+}$. As a result, groundwater sources may be hard in most parts of the continent. Magnesium hazard is less than 50 in most locations.

\section{Conclusion}

The literature is unanimous on the importance of evaluation and understanding of the hydrochemical composition of groundwater under different environments. This study reveals that: 
1. The concentrations of $\mathrm{Fe}^{3+}, \mathrm{Zn}^{2+}, \mathrm{Mg}^{2+}, \mathrm{Na}^{+}, \mathrm{PO}_{4}{ }^{3-}$, and $\mathrm{SO}_{4}{ }^{2-}$ are above World Health Organization (2011) and National Standard for Drinking Water Quality (2007) reference guidelines. Groundwater in the study area is acidic to alkaline in nature;

2. There is a significant difference in concentrations of temperature, $\mathrm{pH}, \mathrm{EC}$, hardness, $\mathrm{Na}^{+}, \mathrm{Zn}^{2+}, \mathrm{Mg}^{2+}$, $\mathrm{PO}_{4}{ }^{3-}, \mathrm{Cl}^{-}, \mathrm{HCO}_{3}{ }^{-}, \mathrm{SO}_{4}{ }^{2-}$, and $\mathrm{NO}_{3}{ }^{-}$between shallow and deep groundwater sources;

3. Groundwater classification using TDS showed that water sources are suitable for drinking and irrigation use;

4. Groundwater classification base on hardness showed that most of the groundwater sources are moderately hard;

5. Groundwater classification based on EC showed that most of the water sources fall in excellent class. The relatively low EC levels in the study area are consequent of low TDS, which is generally low in Sokoto Basin;

6. Groundwater classification based on chloride revealed that most of the water samples fall fresh class, but most groundwater sources fall in severe class based on $\mathrm{NO}_{3}{ }^{-}$ classification;

7. Evaluation of geochemical faces showed that groundwater composition is controlled by rock weathering, even though little inputs were derived from anthropogenic sources. This was further confirmed by the Gibbs model;

8. Result of $\mathrm{Na}+/ \mathrm{Cl}-$ molar ratio indicates that most of the sampling locations have molar ration greater than 1 , which suggests that some parts of $\mathrm{Na}^{+}$were derived from silicate weathering;

9. Most groundwater samples have positive Scholler index, suggesting overall base exchange reactions in the underlying aquifer;

10. Groundwater classification based on Piper diagram revealed two types of faces: $\mathrm{Ca}-\mathrm{Mg}-\mathrm{HCO}_{3}$ and $\mathrm{Ca}-$ $\mathrm{Mg}-\mathrm{SO}_{4}-\mathrm{Cl}$

11. Significant correlations between TDS and $\mathrm{Cl}^{-}$, and positive correlation between TDS and $\mathrm{SO}_{4}$ in shallow groundwater suggest input from anthropogenic sources;

12. Groundwater evaluation using PCA, showed water sources are more influenced by rock mineral as compared to anthropogenic inputs;

13. Groundwater analysis using HCA showed that Group 1 and 2 can be related to natural geogenic processes as it corresponds to ions of natural geogenic origin. Group 3 can be related to both anthropogenic (notably $\mathrm{NO}_{3}{ }^{-}$pollution) and rock weathering;
14. Most of the groundwater samples derived from deep aquifer have SAR value $>18$, whereas, all the groundwater samples from shallow aquifer have $\mathrm{SAR}<18$;

15. Base on $\mathrm{Na}^{+} \%$ samples from shallow groundwater fall in very low to high sodium class, whereas, deep groundwater samples vary between good to excellent;

16. Based on Doneen's chart, permeability indices are excellent in deep groundwater, whereas, in shallow groundwater, PI indices are affected by low salinity water type;

17. The possible reasons for higher KI values in shallow groundwater need to be revealed as it presents a serious environmental problem; based on mean MAR, shallow groundwater in the study area is unfit for irrigation use;

18. Many sources of groundwater in SSA are acidic in composition; Scholler and Versluy's indices suggest an overall base exchange reaction in aquifers underlying SSA; and

19. Kelly's index is less than 1 in most locations in SSA, indicating water which is suitable for irrigation use. MAR is less than 50 in most locations.

Despite the significant difference in water quality parameters and chemical indices, evaluation of shallow and deep groundwater in the study area indicates that groundwater composition is more a product of rock weathering than anthropogenic inputs.

Acknowledgements This study was funded by Tertiary Education Trust Fund (TETFUND) through Federal University Birnin kebbi. We thank all anonymous contributors. The authors also want to thank the anonymous reviewers for their constructive comments and criticism which have helped to improve this paper. We also thank Nasiru A. Bagudo for the map.

Open Access This article is distributed under the terms of the Creative Commons Attribution 4.0 International License (http://creativeco mmons.org/licenses/by/4.0/), which permits unrestricted use, distribution, and reproduction in any medium, provided you give appropriate credit to the original author(s) and the source, provide a link to the Creative Commons license, and indicate if changes were made.

\section{References}

Abd El-Aziz SH (2017) Evaluation of groundwater quality for drinking and irrigation purposes in the North-western area of Libya (Aligeelat). Environ Earth Sci 76(147):1-17

Abdulkareem A, Ishaku JM, Ahmed AS (2011) Mapping of water quality index using GIS in Kaltungo, North-eastern Nigeria. Environ Sci Resour Manag 3:94-106

Ackah M, Agyemang O, Anim AK, Osei J, Bentil NO, Kpattah L, Gyafi ET, Hanson JEK (2011) Assessment of groundwater quality for drinking and irrigation: the case study of Teiman-Oyarifa Community, Ga East Municipality, Ghana. Proc Int Acad Ecol Environ Sci 1(3-4):186-194 
Adams A, Titus R, Pietersen K, Tredoux G, Harris C (2001) Hydrogeochemical characteristics of aquifers near Sutherland in the Western Karoo, South Africa. J Hydrol 21:91-103

Adediji A, Ajibade LT (2005) Quality of well water in Ede area, Southwestern Nigeria. J Hum Ecol 17(3):223-228

Adelana SMA, Olasehinde PI, Vrbka P (2002) Groundwater recharge in the cretaceous and tertiary sediment aquifers of northwestern Nigeria, using hydrochemical and isotopic techniques. Groundw Hum Dev 544:063-069

Adelana SMA, Olasehinde PI, Vrbka P (2003) Isotope and geochemical characterization of surface and subsurface waters in the semi-arid Sokoto Basin, Nigeria. Afr J Sci Technol Sci Eng Ser 4(2):80-89

Adetoyinbo A, Adebo B, Alabi A (2010) Hydrochemical investigation of groundwater quality in selected locations in Uyo, Akwa-Ibom State of Nigeria. N Y Sci J 3:117-122

Agarwal R, Garg PK (2015) Remote sensing and GIS based groundwater potential \& recharge zones mapping using multi-criteria decision-making technique. Wat Resour Manage 30(1):243-260

Ahmed JB, Mansor S (2018) Overview of the application of geospatial technology to groundwater potential mapping in Nigeria. Arab J Geosci 11(504):1-16

Ajibade OM, Ogungbesan GO (2013) Prospect and water quality indices for groundwater development in Ibadan Metropolis, southwestern Nigeria. Dev Sustain 2(1):398-414

Akinluyi FO, Olorunfemi MO, Bayowa OG (2018) Investigation of the influence of lineaments, lineament intersections and geology on groundwater yield in the basement complex terrain of Ondo State, Southwestern Nigeria. Appl Water Sci 8(49):1-13

Ako AA, Shimada J, Hosono T, Ichiyanagi K, Nkeng GE, Fantong WY, Eyong GET, Roger NN (2011) Evaluation of groundwater quality and its suitability for drinking, domestic and agricultural uses in the Banana Plain (Mbanga, Njombe, Penja) of the Cameroon Volcanic Line. Environ Geochem Health 33:559-575

Akombi BJ, Agho KE, Renzaho AM, Hall JJ, Merom DR (2019) Trends in socioeconomic inequalities in child undernutrition: evidence from Nigeria Demographic and Health Survey (20032013). PLoS ONE 14(2):e0211883

Akujieze CN, Coker S, Oteze G (2002) Groundwater in Nigeria-a millennium experience-distribution, practice, problems, and solutions. Hydrogeol J 11(2):259-274

Alagbe SA (2006) Preliminary evaluation of hydrochemistry of the Kalambaina Formation, Sokoto Basin, Nigeria. Environ Geol 51(1):39-45

Aleke CG, Nwachukwu CM (2018) Assessment and characterization of the basement aquifer at Idu-Karmo, area of FCTAbuja, Nigeria, for drinking and irrigation. Environ Earth Sci 77(789):1-11

Alemayehu T, Leis A, Dietzel M (2019) Groundwater evolution in the multilayer aquifers of the Mekelle Sedimentary Outlier (Northern Ethiopia): a chemical and isotopic approach. In: Chaminé H, Barbieri M, Kisi O, Chen M, Merkel B (eds) Advances in sustainable and environmental hydrology, hydrogeology, hydrochemistry and water resources. Advances in science, technology \& innovation (IEREK interdisciplinary series for sustainable development). Springer, Cham, pp 207-209

Ali S, Ebissa M, Gurmu DA, Kumar MV (2015) Groundwater quality assessment of different wells in East Wollenga Zone-Western Ethiopia. Basic Appl Sci 1(2):46-52

Alias N, Liu A, Egodawatta P, Goonetilleke A (2014) Sectional analysis of the pollutant wash-off process based on runoff hydrograph. J Environ Manag 134:63-69

Amadi AN, Aminu T, Okunlolai A, Olasehinde PI, Jimoh MO (2015) Lithologic influence on the hydrogeochemical characteristics of groundwater in Zango, North-west Nigeria. Nat Resour Conserv $3(1): 11-18$
Anderson HR, Ogilbee W (1973) Aquifers in the Sokoto Basin, Northwestern Nigeria, with a description of the general hydrogeology of the region: contributions to the hydrology of AFRICA and the mediterranean region. Geological Survey Water-Supply Paper 1757-L, pp 1-88

Anderson H, Ogilbee W (1979) Aquifers in the Sokoto Basin, northwestern Nigeria, with a general description of general hydrogeology of the region: contributions to the hydrogeology of Africa and Mediterranean Region. Geological survey, Water-supply paper. U.S Agency for International Development 1757

Anku YS, Yakubo BB, Daniel KA, Yidana M (2008) Water quality analysis of groundwater in crystalline basement rocks, Northern Ghana. Environ Geol 1:1-10

Ayers RS, Westcot DW (1976) Water quality for agriculture. FAO Irrigation and Drainage Paper, 29, Rome

Ayoko GA, Singh K, Balerea S, Kokot S (2007) Exploratory multivariate modeling and prediction of the physicochemical properties of surface water and groundwater. J Hydrol 336(1-2):115-124

Azhar SC, Aris AZ, Yusoff MK, Ramli MF, Juahir H (2015) Classification of river water quality using multivariate analysis. Procedia Environ Sci 30:79-84

Basharat M (2012) Spatial and temporal appraisal of groundwater depth and quality in LBDC command-issues and options. Pak J Eng Appl Sci 11:14-29

Bertrand G, Hirata R, Pauwels Cary L, Petelet-Giraud E, Chatton E, Aquilina L, Labasque T, Martins V, Montenegro S, Batista J, Aurouet A, Santos J, Bertolo R, Picot G, Franzen M, Hochreutener R, Braibant G (2016) Groundwater contamination in coastal urban areas: anthropogenic pressure and natural attenuation processes. Example of Recife (PE State, NE Brazil). Contam Hydrol 192:165-180

Besser H, Redhaounia B, Sana B, Ayadi Y, Khelifi F, Hamed Y (2019) Geochemical, isotopic and statistical monitoring of groundwater quality: assessment of the potential environmental impacts of the highly polluted $\mathrm{Cl}$ water in Southwestern Tunisia. J Afr Earth Sci 153:144-155

Betzler A, Lalanne F, Nikiema J, Podgorski J, Pfenninger N, Berg M, Schirmer M (2017) Groundwater arsenic contamination in Burkina Faso, West Africa: predicting and verifying regions at risk. Sci Total Environ 584-585:958-970

Boukari M, Gaye B, Faye A, Faye S (1996) The impact of urban development on coastal aquifers near Cotonou, Benin. J Afr Earth Sci 22(4):403-408

Brancelj A, Žibrat U, Jamnik B (2016) Differences between groundwater fauna in shallow and in deep intergranular aquifers as an indication of different characteristics of habitats and hydraulic connections. J Limnol 75(2):248-261

Cavalcante Júnior R, Vasconcelos Freitas M, Da Silva N, De Azevedo FF (2019) Sustainable groundwater exploitation aiming at the reduction of water vulnerability in the Brazilian semi-arid region. Energies 12(904):1-20

Chen M, Qin X, Zeng G, Li J (2016) Impacts of human activity modes and climate on heavy metal "spread" in groundwater are biased. Chemosphere 152:439-445

Chitsazan M, Aghazadeh N, Mirzaee Y, Golestan Y (2019) Hydrochemical characteristics and the impact of anthropogenic activity on groundwater quality in suburban area of Urmia city, Iran. Environ Dev Sustain 21(1):331-351

Climate-Data Org. https://en.climate-data.org/africa/nigeria/kebbi/ zuru-380580/. Accessed 10/06/2019

Cruz MAS, Gonçalves ADA, De Aragão R, De Amorim JRA, Da Mota PVM, Srinivasan VS, Garcia CAB, De Figueiredo EE (2019) Spatial and seasonal variability of the water quality characteristics of a river in Northeast Brazil. Environ Earth Sci 78(687):1-11 
Dammo MN, Deborah JM, Yusuf IA, Sangodoyin AY (2013) Evaluation of groundwater quality of Konduga Town, Nigeria. Eur Int J Sci Technol 2(5):13-20

Das K, Mukherjee A (2019) Depth-dependent groundwater response to coastal hydrodynamics in the tropical, Ganges river megadelta front (the Sundarbans): impact of hydraulic connectivity on drinking water vulnerability. J Hydrol 575:499-512

David SN, De West RJM (1966) Hydrogeology, 4463. Wiley, New York

Dehnavi R, Sarikhani D, Nagaraju D (2011) Hydrogeochemical and rock water interaction studies in east of Kurdistan, NW of Iran. Environ Sci Res 1(1):16-22

Deng Y, Li H, Wang Y, Duan Y, Gan Y (2014) Temporal variability of groundwater chemistry and relationship with water-table fluctuation in the Jianghan Plain, Central China. Procedia Earth Planet Sci 10:100-103

Dhar RK, Zheng Y, Stute M, Van Geen A, Cheng Z, Shanewaz M, Shamsudduha M, Hoque MA, Rahman MW, Ahmed KM (2008) Temporal variability of groundwater chemistry in shallow and deep aquifers of Araihazar, Bangladesh. J Contam Hydrol 99(1-4):97-111

Doneen LD (1962) The influence of crop and soil on percolating water. In: Proc. 1961 Biennial conference on groundwater recharge, pp 156-163

Dragon K (2008) The Influence of anthropogenic contamination on the groundwater chemistry of a semi-confined aquifer (The Wielkopolska Buried Valley Aquifer, Poland). Water Resour Manag 22:343-355

du Preez JW, Berber W (1965) The distribution of chemical quality of groundwater in Northern Nigeria. Niger Geol Surv Bull $36: 38-45$

Duvbiama OA, Egbuna CK (2013) Physicochemical assessment of groundwater quality in Akure, Southern Nigeria. Civ Eng Urb $3(1): 25-28$

Ebrahim GY, Villholth KG, Boulos M (2019) Integrated hydrogeological modelling of hard-rock semi-arid terrain: Supporting sustainable agricultural groundwater use in Hout catchment, Limpopo Province, South Africa. Hydrogeol J 1-17

Edet A (1990) Application of photogeologic and electromagnetic techniques to groundwater exploration in northwestern Nigeria. J Afr Earth Sci 11(34):321-328

Edmunds WM (2009) Geochemistry's vital contribution to solving water resource problems. Appl Geochem 24(6):1058-1073

Ekpoh IJ, Ekpenyong N (2011) Effects of recent climate variations on groundwater yield in Sokoto region of Northern Nigeria. Bus Soc Sci 2(7):251-256

Emujakporue G, Ofoha CC, Kiani I (2018) Investigation into the basement morphology and tectonic lineament using aeromagnetic anomalies of Parts of Sokoto Basin, North Western, Nigeria. Egypt J Pet 27(4):671-681

Eneke GT, Anyonghe SN, Chandrasekharam D, Ntchancho R, Ako AA, Mouncherou OF, Thambiridurai P (2011) Controls on groundwater chemistry in highly urbanised area. Environ Res 5(2):475-490

Eni DI, Obiefuna JN, Oko C, Ekwork I (2011) Impact of urbanization on sub-surface water quality in Calabar Municipality, Nigeria. Int J Hum Soc Sci 1(10):167-172

EPA (2001) Environmental Protection Agency. Parameters of water quality: interpretation and standards. An Ghniomhaireacht um Chaomhnu Comhshaoil, p 132. Ireland. Available at: https:// www.epa.ie/pubs/advice/water/quality/Water_Quality.pdf

Erban LE, Gorelick SM (2016) Closing the irrigation deficit in Cambodia: implications for transboundary impacts on groundwater and Mekong River flow. J Hydrol 535:85-92

Ette OJ, Okuofu CA, Adie DB, Igboro SB, Alagbe SA, Etteh CC (2017) Application of environmental isotope to assess the renewability of groundwater of continental intercalaire aquifer of Sokoto Basin in North-western Nigeria. Groundw Sustain Dev 4:5-41

Fabbri P, Piccinini L, Marcolongo E, Pola M, Conchetto E, Zangheri P (2016) Does a change of irrigation technique impact on groundwater resources? A case study in Northeastern Italy. Environ Sci Policy 63:63-75

Fantombi KJ, Ahoyo TA, Nonfodji O, Aminou T (2012) Physicochemical and bacterial characteristics of groundwater and surface water quality in the Kagbe Town: treatment Essays, with Moringa Oleifera seeds. Water Resour Prot 4:1001-1008

Farid H, Mahmood-Khan Z, Ali A, Mubeen M, Anjum M (2017) Sitespecific aquifer characterization and identification of potential groundwater areas in Pakistan. Environ Stud 26(1):17-27

Faye SC, Faye S, Wohnlich S, Gaye CB (2004) An assessment of the risk associated with urban development in the Thiaroye area (Senegal). Environ Geol 45:312-322

Fernández-Cirelli F, Arumí JL, Rivera, D, Boochs PW (2009) Environmental effects of irrigation in arid and semi-arid regions. Chil J Agric Res 69(1):27-40

Fianko JR, Osse S, Adomako D, Achel DG (2007) Relationship between land use and groundwater quality in six districts in the eastern region of Ghana. Environ Monit Assess 153:139-146. https://doi.org/10.1007/s10661-008-0344-0

Fillion M, Blais JM, Yumvihoze E, Nakajima M, Workman P, Osborne G, Chan HM (2014) Identification of environmental sources of lead exposure in Nunavut (Canada) using stable isotope analyses. Environ Int 71:63-73

Flörke M, Schneider C, Mcdonald RI (2018) Water competition between cities and agriculture driven by climate change and urban growth. Nat Sustain 1(1):51-58

Gada MA (2014) Understanding the water balance of basement complex areas in Sokoto Basin, North-west Nigeria for improved groundwater management. PhD thesis, School of Applied Sciences, Environmental Science and Technology, Cranfield University, 203

Gebrehiwot A, Tadesse N, Jigar E (2011) Application of water quality index to assess suitability of groundwater quality for drinking purposes in Hantebet Watershed, Tigray, Northern Ethiopia. Food Agric Sci 1(1):22-30

Geyh MA, Wirth K (1980) 14C ages of confined groundwater from the Gwandu aquifer, Sokoto Basin, northern Nigeria. J Hydrol 48(3-4):281-288

Gibbs RJ (1970) Mechanisms controlling world water chemistry. Sci New Ser 170(3962):1088-1090

Goswamee DS, Shah PK, Pate YS (2015) Analysis of quality of groundwater and its suitability for irrigation purpose in Visnagar Taluka, Mehsana District, Gujarat. Sci Eng Technol Res 04(16):2907-2911

Graham WBR, Pishiria IW, Ojo OI (2006) Monitoring of groundwater quality for small-scale irrigation: case studies in the Southwest Sokoto-Rima Basin, Nigeria. Agric Eng Int 3:1-9

Gu H, Ma F, Guo J, Zhao H, Lu R, Liu G (2017) A spatial mixing model to assess groundwater dynamics affected by mining in a coastal fractured aquifer, China. Mine Water Environ 37(2):405-420

Han S, Zhang F, Zhang H, An Y, Wang Y, Wu X, Wang C (2013) Spatial and temporal patterns of groundwater arsenic in shallow and deep groundwater of Yinchuan Plain, China. J Geochem Explor 135:71-78

Haruna R, Ejobi F, Kabagambe K (2005) The quality of water from protected springs in Katwe and Kesenyi Pareshes, Kampala city, Uganda. Afr Health Sci 5(1):14-20

Hellens AV (2013) Groundwater quality of Malawi-fluoride and nitrate of the Zomba-Phalombe plain. Degree Project in Biology, Department of Soil and Environment. Swedish University of Agricultural Sciences, 36 
Hertel TW, Liu J (2016) Implications of water scarcity for economic growth. OECD Environment Working Papers (109). OECD Publishing, Paris. https://doi.org/10.1787/5jlss1611r32-en-58

Hildebrandt A, Guillamon M, Lacorte S, Tauler R, Barcelo D (2008) Impact of pesticides used in agriculture and vineyards to surface and groundwater quality (North Spain). Water Res 42(13):3315-3326

Holbrook WS, Marcon V, Bacon AR, Brantley SL, Carr BJ, Flinchum BA, Richter DD, Riebe CS (2019) Links between physical and chemical weathering inferred from a 65 -m-deep borehole through Earth's critical zone. Sci Rep 9(1):4495

Hubalek V, Wu X, Eiler A, Buck M, Heim C, Dopson M, Bertilsson S, Ionescu D (2016) Connectivity to the surface determines diversity patterns in subsurface aquifers of the Fennoscandian shield. ISME J 10(10):2447-2458

Hughes DA (2019) Facing a future water resources management crisis in sub-Saharan Africa. J Hydrol Reg Stud 23:1-11

Ibemenuga KN, Anaoja DA (2014) Assessment of groundwater quality in wells within the Bombali District, Sierra Leone. Anim Res Int 11(1):1905-1916

Izah SC, Chakrabarty N, Srivastav AL (2016) A review on heavy metal concentration in potable water sources in Nigeria: human health effects and mitigating measures. Expo Health 8(2):285-304

Jebreen H, Banning A, Wohnlich S, Niedermayr A, Ghanem M, Wisotzky F (2018) The influence of karst aquifer mineralogy and geochemistry on groundwater characteristics: West Bank, Palestine. Water 10(12): 1829

Joseph A, Bamidele O (2018) Application of remote sensing method for geological interpretation of Sokoto Plain, Nigeria. S Afr J Geomat 7(3):36-371

Joshi SK, Rai SP, Sinha R, Gupta S, Densmore AL, Rawat YS, Shekhar $S$ (2018) Tracing groundwater recharge sources in the northwestern Indian alluvial aquifer using water isotopes $\left(\delta^{18} \mathrm{O}, \delta^{2} \mathrm{H}\right.$ and $\left.{ }^{3} \mathrm{H}\right)$. J Hydrol 559:835-847

Kamba AH, Muhammad S, Illo AG (2018) Basement depth estimates of some part of Lower Sokoto Sedimentary Basin, North-western Nigeria, using spectral depth analysis. Int J Mar Atmos Earth Sci 6(1):1-9

Kane CH, Diene M, Fall M, Sarr B, Thiam A (2012) Reassessment of the resources of a deep aquifer system under physical and chemical constraints: the Maastrichtian Aquifer. Water Resour Prot 4:217-223

Kashiwagi H, Shikazono N, Ogawa Y, Higuchi Y, Takahashi M, Tanaka Y (2006) Mineralogical and biological influences on groundwater chemistry of the Boso Peninsula, Chiba, central Japan: implications for the origin of groundwater in sedimentary basins. Geochem J 40:345-361

Kattan Z (2018) Using hydrochemistry and environmental isotopes in the assessment of groundwater quality in the Euphrates alluvial aquifer, Syria. Environ Earth Sci 77(45):1-18

Kelly WP (1940) Permissible composition and concentration of irrigation water. Proc Am Soc Civ Eng 66:607-613

Khatri N, Tyagi S (2014) Influences of natural and anthropogenic factors on surface and groundwater quality in rural and urban areas. Front Life Sci 8(1):23-39

Kogbe CA (1981) Cretaceous and Tertiary of the Iullemmeden Basin in Nigeria (West Africa). Cretac Res 2:129-186

Kogbe CA (1986) Geology of the upper cretaceous and tertiary sediments of the Nigerian sector of the Iullemeden Basin (WestAfrica). Cretac Res 1:197-211

Kohlhepp B, Lehmann R, Seeber P, Küsel K, Trumbore SE, Totsche KU (2017) Aquifer configuration and geostructural links control the groundwater quality in thin-bedded carbonate-siliciclastic alternations of the Hainich CZE, central Germany. Hydrol Earth Syst Sci 21(12):6091-6116
Kokot S, Stewart S (1995) An exploratory study of mercerized cotton fabrics by DRIFT spectroscopy and chemometrics. Text Res J 64(11):643-651

Kokot S, Marahusin L, Schweinsbe DP (1994) Characterizing oxidatively damaged cotton fabrics part II: a model for the catalytic damage phenomenon using electrogenerated oxygen. Text Res J 64(12):710-716

Kokot S, Grigg M, Panayiotou H, Phuong T (1998) Data interpretation by some common chemometrics methods. Electroanalysis 10(16):1081-1088

Kong X, Wang S, Liu B, Sun H, Sheng Z (2018) Impact of water transfer on interaction between surface water and groundwater in the lowland area of North China Plain. Hydrol Proc 32(13):2044-2057

Kudamnya EA, Andongma WT (2017) Predictive mapping for groundwater within Sokoto Basin, North Western Nigeria. J Geogr Environ Earth Sci Int 10(2):1-14

Kulabako NR, Nalubega M, Thunvik R (2007) Study of the impact of land use and hydrogeological settings on the shallow groundwater quality in a peri-urban area of Kampala, Uganda. Sci Total Environ 381(1-3):180-199

Kumar PJS, Delso PD, James EJ (2014) Evaluation of groundwater chemistry in Vaniyambadi industrial area with special reference on irrigation utility. Nat Acad Lett 37(6):493-502

Kumar M, Ramanathan AL, Mukherjee A, Sawlani R, Ranjan S (2019) Delineating sources of groundwater recharge and carbon in Holocene aquifers of the central Gangetic basin using stable isotopic signatures. Isotopes Environ Health Stud 55(3):254-271

Kummu M, Guillaume JH, De Moel H, Eisner S, Florke M, Porkka M, Siebert S, Veldkamp TI, Ward PJ (2016) The world's road to water scarcity: shortage and stress in the 20th century and pathways towards sustainability. Sci Rep 6:38495

Laurent M, Francois A, Marie MJ (2010) Assessment of groundwater quality during dry season in Southeastern Brazzaville, Congo. Appl Biol Pharm Technol 1(3):762-769

Li P (2018) Mine water problems and solutions in China. Mine Water Environ 37(2):217-221

Li M, Liu Z, Chen Y, Hai Y (2016) Characteristics of iron corrosion scales and water quality variations in drinking water distribution systems of different pipe materials. Water Res 106:593-603

Li S, Luo W, Jia Z, Tang S, Chen C (2018) The pros and cons of encouraging shallow groundwater use through controlled drainage in a salt-impacted irrigation area. Water Resour Manag 32(7):2475-2487

Lin CY, Abdullah MH, Praveena SM, Yahaya AHB, Musta B (2012) Delineation of temporal variability and governing factors influencing the spatial variability of shallow groundwater chemistry in a tropical sedimentary island. J Hydrol 432-433:26-42

Liu P, Hoth N, Drebenstedt C, Sun Y, Xu Z (2017) Hydro-geochemical paths of multi-layer groundwater system in coal mining regions - using multivariate statistics and geochemical modeling approaches. Sci Total Environ 601-602:1-14

Long X, Zhang K, Yuan R, Zhang L, Liu Z (2019) Hydrogeochemical and isotopic constraints on the pattern of a deep circulation groundwater flow system. Energies 12(3):404

Locatelli L, Binning PJ, Sanchez-Vila X, Sondergaard GL, Rosenberg L, Bjerg PL (2019) A simple contaminant fate and transport modelling tool for management and risk assessment of groundwater pollution from contaminated sites. J Contam Hydrol 221:35-49

Love D, Hallbauer D, Amos A, Hronova R (2004) Factor analysis as a tool in groundwater quality management: two southern African case studies. Phys Chem Earth 29:1135-1143

Love D, Zingoni E, Ravengai S, Owen R, Moyece W, Mangeya P, Meck M, Musiwa K, Amos ZH, Hrannova R, Giadidzanwa P, Magadzire F, Magadza C, Tekere M, Nyama Z, Wuta M, 
Love I (2006) Characterization of diffuse pollution of shallow groundwater in the Harare urban area, Zimbabwe. In: Xu Y, Usher B (eds) Groundwater pollution in Africa. CRC Press, Boca Raton, pp 65-75

Machiwal D, Jha MK (2015) Identifying sources of groundwater contamination in a hard-rock aquifer system using multivariate statistical analyses and GIS-based geostatistical modeling techniques. J Hydrol Reg Stud 4:80-110

Makinde V, Adeleke OO, Eruola AO, Okeyode IC, Akinboro FG, Alatise OO, Dada OF (2017) Impact of climate change on groundwater resources in Odeda Local Government Area, Ogun State, Southwest Nigeria. Afr Rev Phys 12:1-13

Makoto T, Jeffrey VT, Smith AJ (2003) Evaluations of groundwater discharge rates from subsurface temperature in Cockburn Sound. Biogeochemistry 6:111-124

Mande AS, Liu M, Boundjou G, Liu F, Bawa ML, Chen H (2012) Nitrate in drinking water: a major polluting component of groundwater in gulf region aquifers, south Togo. Phys Sci $7: 144-152$

Mangore E, Taigben AE (2004) Land-use impacts on the quality of groundwater in Bulawayo. Water S Afr 30:453-464

Marghade D, Malpe DB, Zade AB (2010) Geochemical characterization of groundwater from North-eastern part of Nagpur urban, Central India. Environ Earth Sci 62(7):1419-1430

Matini L, Tathy C, Moutou JM (2012) Seasonal groundwater variation in Brazzaville, Congo. Chem Sci 2(1):7-14

Meybeck M (1987) Global chemical weathering of surficial rocks estimated from river dissolved loads. Am J Sci 287:401-428

Miguntanna NS, Egodawatta P, Kokot S, Goonetilleke A (2010) Determination of a set of surrogate parameters to assess urban stormwater quality. Sci Total Environ 408(24):6251-6259

Minnig M, Moeck C, Radny D, Schirmer M (2018) Impact of urbanization on groundwater recharge rates in Dübendorf, Switzerland. J Hydrol 563:1135-1146

Mohammed LN, Aboh HO, Emenike EA (2007) A regional geoelectric investigation for groundwater exploration in Minna area, northwest Nigeria. Sci World J 2(3):15-19

Mondal NC, Singh VP, Singh VS, Saxena VK (2010) Determining the interaction between groundwater and saline water through groundwater major ions chemistry. J Hydrol 388(1-2):100-111

Montcoudiol N, Banks D, Isherwood C, Gunning A, Burnside N (2019) Baseline groundwater monitoring for shale gas extraction: definition of baseline conditions and recommendations from a real site (Wysin, Northern Poland). Acta Geophys 67(1):365-384

Moody RTJ, Sutcliffe PJC (1991) The Cretaceous deposits of the Iullemmeden Basin of Niger, central West Africa. Cretac Res 12:137-157

Morris PJ, Baird AJ, Eades PA, Surridge BWJ (2019) Controls on near-surface hydraulic conductivity in a raised bog. Water Res Res 55:1531-1543

Muhammad MN (2012) Assessment of groundwater quality in lowincome high-density areas of Kaduna Metropolis. Acad Res Int 2(1):183-190

Muhammad SB, Saad R (2018) Regional structural architecture of part of Northern Nigeria basement complex inferred from upward continuation of magnetic field intensity data. J Phys Conf Ser 1083:012057. https://doi.org/10.1088/1742-6596/1083/1/012057

Mukate SV, Panaskar DB, Wagh VM, Baker SJ (2019) Understanding the influence of industrial and agricultural land uses on groundwater quality in semiarid region of Solapur, India. Environ Dev Sustain. https://doi.org/10.1007/s10668-019-00342-3

Musa JJ, Ahanonu JJ (2013) Quality assessment of shallow groundwater in some selected agrarian communities in Patigi local government area, Nigeria. Basic Appl Sci 1(3):548-563

Narr CF, Singh H, Mayer P, Keeley A, Faulkner B, Beak D, Forshay KJ (2019) Quantifying the effects of surface conveyance of treated wastewater effluent on groundwater, surface water, and nutrient dynamics in a large river floodplain. Ecol Eng 129:123-133

National Standard for Drinking Water Quality (2007) Nigerian standard for drinking water quality. Nigerian Industrial Standard, NIS, vol 554, pp 13-14

Ngabirano H, Byamugisha D, Ntambi E (2016) Effects of seasonal variations in physical parameters on quality of gravity flow water in Kyanamira Sub-County, Kabale District, Uganda. Water Resour Prot 8:1297-1309

Nsengimana H, Masengessho F, Nyirimbibi DK (2012) Some physicochemical characteristics of groundwater in Rwanda. Rwanda J 25:101-109

Nwankwo LI (2015) Estimation of depths to the bottom of magnetic sources and ensuing geothermal parameters from aeromagnetic data of Upper Sokoto Basin, Nigeria. Geothermics 54:76-81

Nwankwo LI, Shehu AT (2015) Evaluation of Curie-point depths, geothermal gradients and near-surface heat flow from high-resolution aeromagnetic (HRAM) data of the entire Sokoto Basin, Nigeria. Volcanol Geother Res 305:45-55

Nwankwoala H (2015) Hydrogeology and groundwater resources of Nigeria. N Y Sci J 8(1):89-100

Nwankwoloa HO, Ngah SA, Ushie FA, Amadi AN (2014) Statistical characterization of groundwater quality in Port Harcourt, Southern Nigeria. Sci Issues Res Essays 2(8):338-341

Odukoya AM (2015) Geochemical and quality assessment of groundwater in some Nigerian basement complex. Int J Environ Sci Technol 12:3643-3656

Offodile ME (2002) Groundwater study and development in Nigeria, 2nd edn. Mecon Geology and Engineering Services Limited, Jos

Olatunji S, Musa A (2013) Estimation of aquifer hydraulic characteristics from surface geoelectrical methods: case study of the Rima Basin, North Western Nigeria. Arab J Sci Eng 39(7):5475-5487

Oyedele EAA, Olayinka AI (2019) On the application of coefficient of anisotropy as an index of groundwater potential in a typical basement complex of Ado Ekiti, Southwest, Nigeria. Phys Sci Int J 22(1):1-10

Olorunfemi MO, Oni AG (2019) Integrated geophysical methods and techniques for siting productive boreholes in basement complex terrain of southwestern Nigeria. Ife J Sci 21(1):1-13

Olsen RL, Chappell RW, Loftis JC (2012) Water quality sample collection, data treatment and results presentation for principal components analysis-literature review and Illinois River Watershed case study. Water Res 46(9):3110-3122

Olubusola I, Daniel A, Oladimeji O (2018) Modeling of groundwater yield using GIS and electrical resistivity method in a basement complex Terrain, Southwestern Nigeria. J Geogr Environ Earth Sci Int 16(1):1-17

Omolabi PO, Fagbohun BJ (2019) Mapping suitable sites for water storage structure in the Sokoto-Rima basin of northwest Nigeria. Remote Sens Appl Soc Environ 13:12-30

Onuigbo EN, Okoro AU, and Nwokeabia CN (2017) Clay minerals as indicator of phosphatogenesis: a case study of Sokoto Basin, Northwestern Nigeria. J Nat Sci Res 7(14):21-27

Oseji JO, Egbai JC (2019) Aquifer characterization based on geoelectric survey data in Issele Uku, Delta State, Nigeria. AIP Adv 9(8):1-12

Oyeyemi K, Aizebeokhai A (2018) Geoelectrical investigations for groundwater exploration in Crystalline Basement Terrain, SW Nigeria: implications for groundwater resources sustainability. Int J Civ Eng Technol (IJCIET) 9(6):7654-7772

Panaskar DB, Wagh VM, Muley AA, Mukate SV, Pawar RS, Aamalawar ML (2016) Evaluating groundwater suitability for the domestic, irrigation, and industrial purposes in Nanded Tehsil, Maharashtra, India, using GIS and statistics. Arab J Geosci 9(615):1-16 
Pandith M, Kaplay RD, Potdar SS, Sangnor H, Rao AD (2017) Impact of urbanization coupled with drought situations on groundwater quality in shallow (basalt) and deeper (granite) aquifers with special reference to fluoride in Nanded-Waghala Municipal Corporation, Nanded District, Maharashtra (India). Environ Monit Assess 189(9):428

Parisi A, Monno V, Fidelibus MD (2018) Cascading vulnerability scenarios in the management of groundwater depletion and salinization in semi-arid areas. Int J Disaster Risk Reduc 30:292-305

Park Y, Kim Y, Park SK, Shin WJ, Lee KS (2018) Water quality impacts of irrigation return flow on stream and groundwater in an intensive agricultural watershed. Sci Total Environ 630:859-868

Paul II, Bayode EN (2012) Watershed characteristics and their implication for hydrologic response in the Upper Sokoto Basin, Nigeria. J Geogr Geol 4(2):147-155

Piper AM (1944) A graphical procedure in the geochemical interpretation of water analysis. Am Geophys Union 25:914-928

Powell JW, Welsh JM, Farquharson R (2019) Investment analysis of solar energy in a hybrid diesel irrigation pumping system in New South Wales, Australia. J Clean Prod 224:444-454

Pulido-Bosch A, Rigol-Sanchez JP, Vallejos A, Andreu JM, Ceron JC, Molina-Sanchez L, Sola F (2018) Impacts of agricultural irrigation on groundwater salinity. Environ Earth Sci 77(197):1-14

Qin R, Wu Y, Xu Z, Xie D, Zhang C (2013) Assessing the impact of natural and anthropogenic activities on groundwater quality in coastal alluvial aquifers of the lower Liaohe River Plain, NE China. Appl Geochem 31:142-158

Ragunath HM (1987) Groundwater. Wiley Eastern Ltd., New Delhi, p 563

Rajmohan N, Patel N, Singh G, Amarasinghe UA (2017) Hydrochemical evaluation and identification of geochemical processes in the shallow and deep wells in the Ramganga Sub-Basin, India. Environ Sci Pollut Res Int 24(26):21459-21475

Rakotondrabe F, Ndam Ngoupayou JR, Mfonka Z, Rasolomanana EH, Nyangono Abolo AJ, Ako Ako A (2018) Water quality assessment in the Betare-Oya gold mining area (East-Cameroon): multivariate statistical analysis approach. Sci Total Environ 610-611:831-844

Redwan M, Abdel Moneim AA (2016) Factors controlling groundwater hydrogeochemistry in the area west of Tahta, Sohag, Upper Egypt. J Afr Earth Sci 118:328-338

Richards LA (1954) Diagnosis and improvement of saline and alkali soils. Soil Sci 78(2):154

Sadashivaiah C, Ramakrishnaiah CR, Ranganna G (2008) Hydrochemical analysis and evaluation of groundwater quality in Tumkur Taluk, Karnataka State, India. Environ Res Publ Health 5(3):158-164

Sawyer CN, McCarty PL (1967) Chemistry for sanitary engineers. In: Chemistry for sanitary engineers. McGraw-Hill

Scholler H (1965) Qualitative evaluation of groundwater resources

Selck BJ, Carling GT, Kirby SM, Hansen NC, Bickmore BR, Tingey DG, Rey K, Wallace J, Jordan JL (2018) Investigating anthropogenic and geogenic sources of groundwater contamination in a semi-Arid Alluvial Basin, Goshen Valley, UT, USA. Water Air Soil Pollut 229(6186):1-17

Selvakumar S, Ramkumar K, Chandrasekar N, Magesh NS, Kaliraj S (2017) Groundwater quality and its suitability for drinking and irrigational use in the Southern Tiruchirappalli district, Tamil Nadu, India. Appl Wat Sci 7(1):411-420

Shahid S, Wang XJ, Rahman MM, Hasan R, Harun SB, Shamsudin S (2015) Spatial assessment of groundwater over-exploitation in Northwestern Districts of Bangladesh. J Geol Soc India 85:463-470

Shahzad MW, Burhan M, Ang L, Ng KC (2017) Energy-water-environment nexus underpinning future desalination sustainability. Desalination 413:52-64
Shang Y, You B, Shang L (2016) China's environmental strategy towards reducing deep groundwater exploitation. Environ Earth Sci 75(1439):1-9

Soladoye O, Ajibade LT (2014) A groundwater quality study of Lagos, Nigeria. Appl Sci Technol 4(4):271-281

Sperling J, Sarni W (2019) Sustainable and resilient water and energy futures: from new ethics and choices to urban nexus strategies, pp 1-19. Available at: https://www.intechopen.com/books/water -and-sustainability/sustainable-and-resilient-water-and-energ y-futures-from-new-ethics-and-choices-to-urbannexus-strate

Stuyfzand PJ (1989) A new hydrochemical classification ofwater types. IAHS Publ 182:89-98

Szablocs I, Darab C (1964) The influence of irrigation water of high sodium carbonate content of soils. In: Proceedings of 8th international congress of ISSS, transmission, vol 2, pp 803-812

Tajudeen OA, Damilola OS, Medina U (2019) Geophysical survey of basement complex terrain using electrical resistivity method for groundwater potential. World News Nat Sci 23:154-165

Takem GE, Chandrasekhararam D, Ayondhe SN, Thambidurai P (2010) Pollution of characteristics of alluvial groundwater from springs and bore wells in semi-urban informal settlements of Douala, Cameroon, Western Africa. Environ Earth Sci 61:287-298

Tam VT, Nga TTV (2018) Assessment of urbanization impact on groundwater resources in Hanoi, Vietnam. J Environ Manag 227:107-116

Tay C, Kortatsi B (2008) Groundwater quality studies: a case study of the Densu Basin, Ghana. West Afr J Appl Ecol 12:1-16

Thomas EA, Needoba J, Kaberia D, Butterworth J, Adams EC, Oduor P, Macharia D, Mitheu F, Mugo R, Nagel C (2019) Quantifying increased groundwater demand from prolonged drought in the East African Rift Valley. Sci Total Environ 666:1265-1272

Todd DK, Mays LW (2005) Groundwater hydrology. 3rd edn. Wiley, New York, USA, p 652

Toyin A, Adekeye OA (2019) Assessment of chemical and mineralogical composition of tertiary shales from the Nigerian sector of Iullemmeden basin: implication for paleoclimate and provenance. J Afr Earth Sci 150:485-498

Toyin A, Adekeye OA, Bale RB, Sanni ZJ, Jimoh OA (2016) Lithostratigraphic description, sedimentological characteristics and depositional environments of rocks penetrated by Illela borehole, Sokoto Basin, NW Nigeria: a connection between Gulf of Guinea Basins. J Afr Earth Sci 121:255-266

Tredoux G, van der Marwe B, Piters I (2009) Artificial recharge of the Windhoek aquifer, Namibia: water quality considerations. Boletin Geologico y Minero 120(2):269-278

Ugya AY, Umar SA, Yusuf AS (2015) Assessment of well water quality: a case study of Kaduna South Local Government Area, Kaduna State, Nigeria. Environ Sci Toxicol 3(3):39-43

Ukpong EC (2011) Groundwater quality at Idu Uruan water headwork and adjoining environment in Akwa Ibom State, Nigeria. Environ Issues Agric Dev Ctries 3(2):106-112

Uma KO (1993) Nitrates in shallow (regolith) aquifers around Sokoto Town, Nigeria. Environ Geol 21:70-76

USSL (1954) Diagnosis and improvements of saline and alkali soils. U.S Department of Agriculture Handbook 60:160

Veldkamp TIE, Wada Y, Aerts J, Doll P, Gosling SN, Liu J, Masaki Y, Oki T, Ostberg S, Pokhrel Y, Satoh Y, Kim H, Ward PJ (2017) Water scarcity hotspots travel downstream due to human interventions in the 20th and 21st century. Nat Commun 8:15697

Venkatramanan S, Chung SY, Selvam S, Lee SY, Elzain HE (2017) Factors controlling groundwater quality in the Yeonjegu District of Busan City, Korea, using the hydrogeochemical processes and fuzzy GIS. Environ Sci Pollut Res Int 24(30):23679-23693

Versluys J (1916) Chemische werkingen in den ondergrond der duinen. Verslag Gewone Vergad. Wis-\& Nat. afd. Kon. Acad. Wetensch. Amsterdam, 25-3-1916, XXIV: 1671-1676. In: Pieter JS (2008)

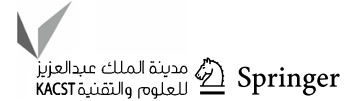


Base exchange indices as indicators of salinization or freshening of (Coastal) aquifers. Kiwa Wat Resear (20th Saltwater Intrusion Meeting), pp 261-265

Vijay R, Khobragade P, Mohapatra PK (2011) Assessment of groundwater quality in Puri City, India: an impact of anthropogenic activities. Environ Monit Assess 177(1-4):409-418

Wada Y, Flörke M, Hanasaki N, Eisner S, Fischer G, Tramberend S, Satoh Y, Van Vliet MTH, Yillia P, Ringler C, Burek P, Wiberg D (2016) Modeling global water use for the 21st century: the Water Futures and Solutions $(\mathrm{WFaS})$ initiative and its approaches. Geosci Model Dev 9(1):175-222

Wagh VM, Panaskar DB, Varade AM, Mukate SV, Gaikwad SK, Pawar RS, Muley AA, Aamalawar ML (2016) Major ion chemistry and quality assessment of the groundwater resources of Nanded tehsil, a part of southeast Deccan Volcanic Province, Maharashtra, India. Environ Earth Sci 75(1481):1-27

Wali SU, Bakari AA (2016) Assessment of groundwater variability over different geologic units across Kebbi State, Nigeria. Zaria Geogr 23(1): 155-165

Wali SU, Umar A, Gada MA (2016) Effects of rainfall fluctuations on groundwater quality in rural communities of Kebbi State, Nigeria. Niger Geogr J 11(1):50-64

Wali SU, Umar KJ, Dankani IM, Abubakar SD, Gada MA, Umar A, Usman AA (2018a) Groundwater hydrochemical characterization in urban areas of southwestern Sokoto Basin Nigeria. SF J Enviorn Earth Sci 1(1):1-17

Wali SU, Umar KJ, Gada MA, Usman A (2018b) Evaluation of shallow groundwater in cretaceous and tertiary aquifers of northern Kebbi State, Nigeria. SF J Env and Earth Sci 1(1):1-11

Wanda E, Monjerezib M, Mwatsetezab JF, Kazembec LN (2011) Hydro-geochemical appraisal of groundwater quality from weathered basement aquifers in Northern Malawi. Phys Chem Earth 36:1197-1207

World Health Organization (2011) Guidelines for drinking-water quality. First Addendum to 3rd edn, vol 1. Geneva, p 515
Wilcox LV (1955) Classification and use of irrigation waters. USDA Circular, 969, Washington, DC

Wu X, Zheng Y, Wu B, Tian Y, Han F, Zheng C (2016) Optimizing conjunctive use of surface water and groundwater for irrigation to address human-nature water conflicts: a surrogate modeling approach. Agric Water Manag 163:380-392

Yidana SM (2010) Groundwater classification using multivariate statistical methods: southern Ghana. J Afr Earth Sci 57(5):455-469

Yidana SM, Bawoyobie P, Sakyi P, Fynn OF (2018) Evolutionary analysis of groundwater flow: application of multivariate statistical analysis to hydrochemical data in the Densu Basin, Ghana. J Afr Earth Sci 138:167-176

Yin S, Xiao Y, Gu X, Hao Q, Liu H, Hao Z, Meng G, Pan X, Pei Q (2019) Geostatistical analysis of hydrochemical variations and nitrate pollution causes of groundwater in an alluvial fan plain. Acta Geophys 67:1191-1203

Young AO (2019) Economic growth and demographic dividend nexus in Nigeria: a vector autoregressive (VAR) approach. Asian Soc Sci 15(2):37-58

Zadawa AN, Omran A (2018) Climate change and water security issues in Africa: introducing partnership procurement for sustainable water projects in Nigeria, pp 127-134. https://doi. org/10.1007/978-981-10-7748-7_6

Zhang Q, Zhang F, Ni Y, Kokot S (2015) Effects of aluminum on amyloid-beta aggregation in the context of Alzheimer's disease. Arab J Chem. https://doi.org/10.1016/j.arabjc.2015.06.019

Zheng Y, Wang L, Chen H, Lv A (2019) Does the geographic distribution of manufacturing plants exacerbate groundwater withdrawal? A case study of Hebei Province in China. J Clean Prod 213:642-649

Publisher's Note Springer Nature remains neutral with regard to jurisdictional claims in published maps and institutional affiliations. 